\title{
Spatial and temporal variations in growth rates along active normal fault systems: an example from The Lazio-Abruzzo Apennines, central Italy
}

\author{
Gerald P. Roberts ${ }^{\mathrm{a}, *}$, Alessandro M. Michetti ${ }^{\mathrm{b}}$ \\ ${ }^{a}$ The Research School of Geological and Geophysical Sciences, Birkbeck College and University College London, Gower Street, London WC1E 6BT, UK \\ ${ }^{\mathrm{b}}$ Universita dell'Insubria, Dipartimento di Scienze, CC.FF.MM., Via Lucini, 3, 22100, Como, Italy
}

Received 5 January 2001; accepted 28 April 2003

\begin{abstract}
The geometry, kinematics and rates of active extension in Lazio-Abruzzo, Italian Apennines, have been measured in order to gain a better understanding of the spatial and temporal variations in fault growth rates and seismic hazards associated with active normal fault systems. We present fault map traces, throws, throw-rates and slip-directions for 17 parallel, en échelon or end-on active normal faults whose 20 $40 \mathrm{~km}$ lengths combine to form a soft-linked fault array ca. $155 \mathrm{~km}$ in length and ca. $55 \mathrm{~km}$ across strike. Throw-rates derived from observations of faulted late-glacial features and Holocene soils show that both maximum throw-rates and throw-rate gradients are greater on centrally-located faults along the strike of the array; total throws and throw gradients show similar spatial variations but with weaker relationships with distance along strike. When summed across strike, throw-rates are increasingly high towards the centre of the array relative to summed throws. We interpret the above to suggest that throw-rates have changed in the recent past (ca. $0.7 \mathrm{Ma}$ ) from spatially-random fault growth rates (initiating at 2.5-3.3 Ma) to growth rates that are greater on centrally-located faults. We interpret this as evidence for fault interaction producing throw-rate variations that drive throw profile readjustment on these crustal scale soft-linked faults. The results are used to discuss seismic hazards in the region, which are quantified in a second paper in this issue.
\end{abstract}

(C) 2003 Elsevier Ltd. All rights reserved.

Keywords: Fault growth rates; Seismic hazards; Normal fault systems

\section{Introduction}

Active normal fault systems can rupture in large magnitude earthquakes producing extensive damage and loss of life (Ms 6.0-7.3; Jackson and White, 1989; e.g. 1915 Fucino, Italy, 33,000 dead (Oddone, 1915; Michetti et al., 1996); 1908 Messina, Italy, 50,000-80,000 dead (Baratta, 1910)). The long-term hazard associated with such faults is fundamentally determined by the rate at which faults slip because average earthquake recurrence intervals tend to decrease as slip-rates increase (Cowie and Roberts, 2001) (Fig. 1). These authors point out that slip-rates tend to be highest on faults located centrally along the strike of an array of faults, implying spatial variations in seismic hazard. If one knew exactly how slip-rates varied with distance along fault arrays, then it would be possible to use this information to help map spatial variations in seismic hazard.

\footnotetext{
* Corresponding author. Tel.: +44-20-76797713; fax: +44-2073830008.

E-mail address: gerald.roberts@ucl.ac.uk (G.P. Roberts).
}

Unfortunately, there are very few databases that detail sliprate variations on active fault systems to an extent that allows the above (Cowie and Roberts, 2001). Instead, seismic hazards associated with active normal faults are commonly mapped using records of instrumental and historical seismicity. However, below we argue that such records will be too short for the full spatial pattern of fault slip-rate variability to emerge as these features only form after a large number of fault-specific seismic cycles (Cowie, 1998). Our belief is that slip-rate databases measured over time periods containing a large number of seismic cycles should provide a more reliable quantification of the geography of seismic hazard than seismicity or geodetic datasets, which generally cover time periods similar to that of a single fault-specific seismic cycle or less.

Two papers are presented in this issue that address the above. In this first paper we detail a throw-rate (vertical component of the slip-rate) database for an active normal fault array in the Lazio-Abruzzo Apennines, central Italy (Fig. 2). The throw-rate data are averaged over $18 \mathrm{kyrs}$ yet 
(a)

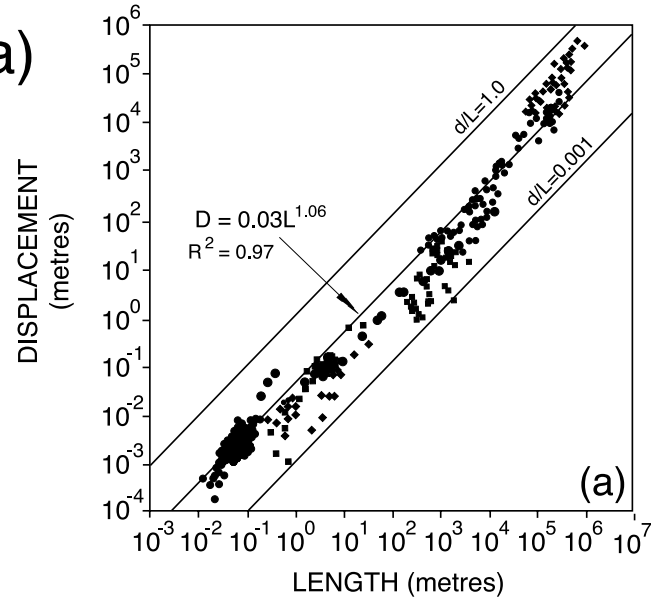

(c)

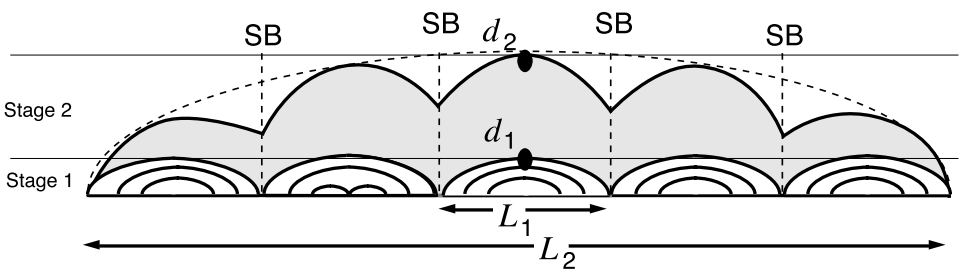

(b)

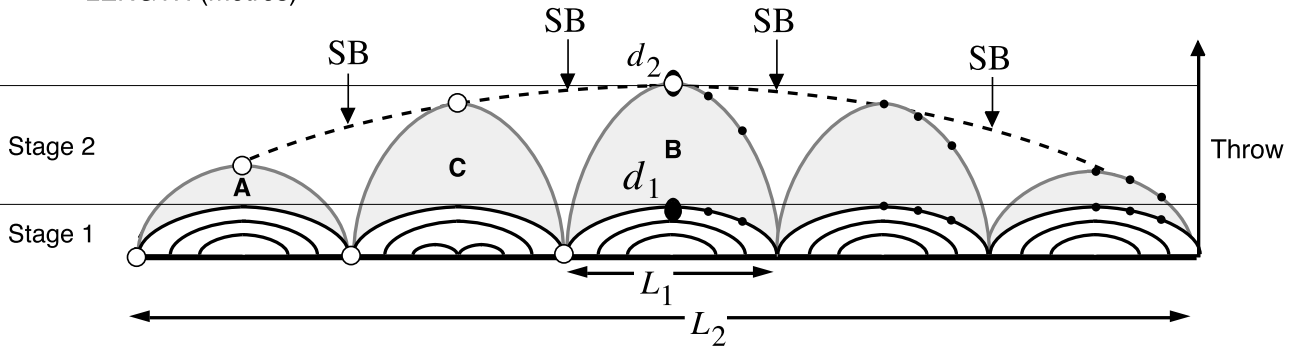

(d)

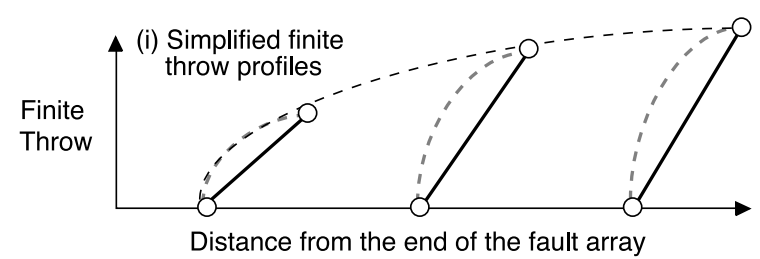

(ii) Simplified throw-rate profiles

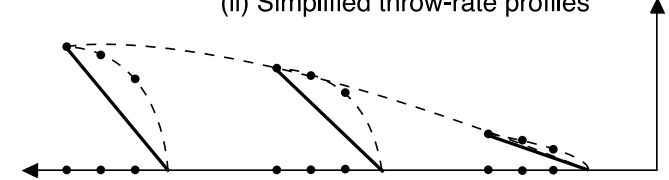

Throw-rate

Distance from the end of the fault array

Distance from the end of the fault array

(e)
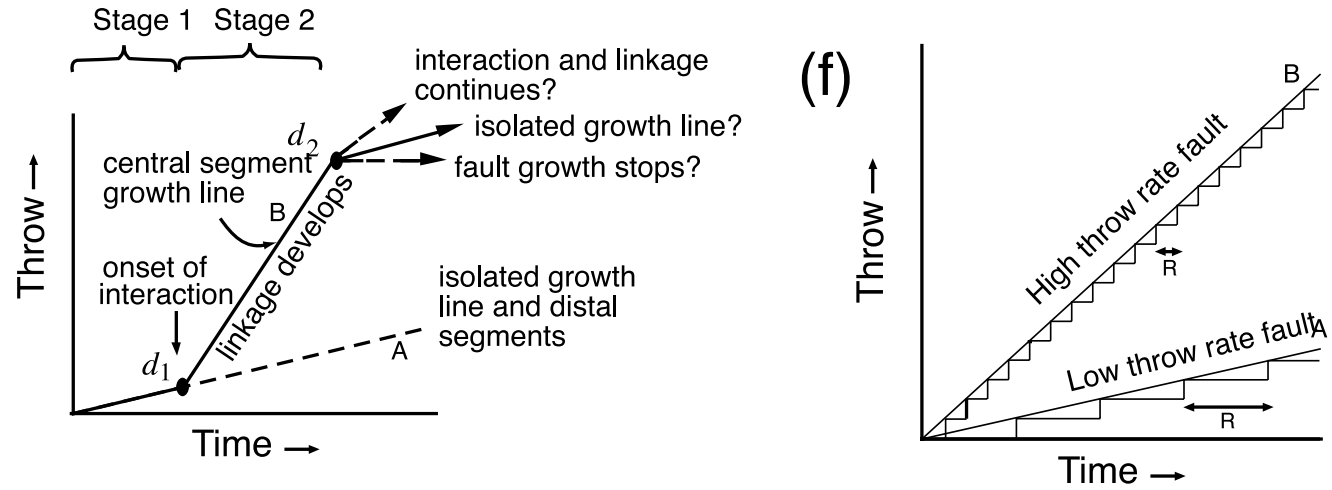

Fig. 1. Conceptual model of fault growth adapted from Cowie and Roberts (2001). (a) Displacement-length relationships for faults world-wide (Schlische et al., 1996). Throws scale with length in a similar way if constant fault dips are assumed. (b) Development of a soft-linked fault array whose overall throw/length ratio is self-similar with that of the component faults prior to interaction. Faults initially grow in Stage 1 by increasing their lengths and throws (e.g. faults A and B) or through this and linkage of smaller faults (e.g. fault C). When the faults achieve a certain size they interact so that the overall fault-array throw profile, and that for individual faults, changes. Values for the throw/length ratios increase with time until the end of Stage 2. At the end of Stage 1, individual faults have displacement $(d)$ to length $(L)$ ratios of $d_{1}=\gamma L_{1}$, whilst at the end of Stage 2 the overall array achieves $d_{2}=\gamma L_{2}$. Fault B has a displacement/length ratio of $\gamma L_{2} / L_{1}$ at the end of Stage 2 if the faults remain soft-linked. The $d / L$ values must increase more on the central faults simply because of the shape of the displacement profile for the overall array at the end of Stage 2 . To achieve the implied spatial variation in $d / L$ ratios for individual faults, central faults must have higher throw-rates (vertical component of the displacement-rate) than distal ones. Black dots and white circles show values used in (d). (c) Similar to (b) but for a hard-linked array. The spatial variation in throw-rates in Stage 2 is similar to that for (b). (d) Spatial variation in throw gradients (i), and throw-rate gradients (ii) at the end of Stage 2 for a soft-linked array (b). (e) Graph showing how throw-rates vary through time on central and distal faults within either softlinked or hard-linked arrays. (f) Graph showing how earthquake recurrence intervals $(R)$ differ for faults with different throw-rates assuming all slip occurs with a given earthquake magnitude. 

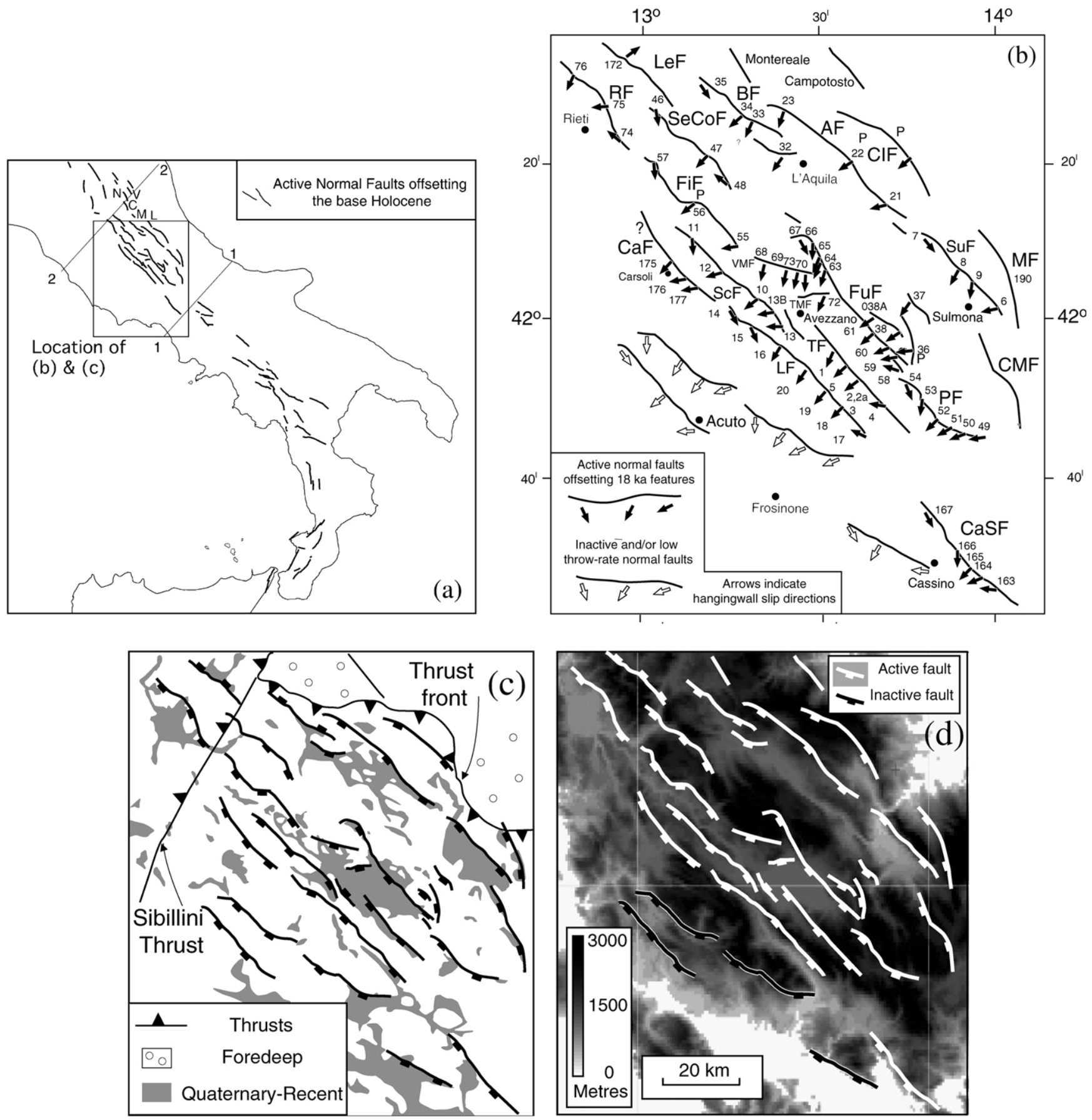

Fig. 2. Location maps for the study area. (a) Map of central-southern Italy showing major active normal faults that have slipped after the end of the last glacial maximum at $18 \mathrm{ka}$. Transects 1 and 2 are discussed in the text (Section 4.4). Faults close to transect 2 modified from Blumetti (1995) and Tondi (2000) and field studies by the authors. Faults NW of transect 2 from Boncio and Lavecchia (2000) and Tondi (2000) and field studies by the authors. N-Norcia Fault; CCittareale Fault; M-Montereale Fault; L—Laga Fault; V-Mt. Vettore Fault. (b) Map of Lazio-Abruzzo showing active and inactive normal faults. Locality numbers refer to the localities in Table 1 and Figs. 3 and 6. Fault-slip directions are from the data in Fig. 6. RF-Rieti Fault; LeF-Leonessa Fault; SeCoFSella di Corno Fault; FiF—Fiamignano Fault; BF—Barete Fault; AF—L' Aquila Fault; CIF—Campo Imperatore Fault; CaF-Carsoli Fault; ScF—Scurcola Fault; LF-Liri Fault; FuF—Fucino Fault; TF-Trasacco Fault; PF—Pescasseroli Fault; SuF—Sulmona Fault; MF-Maiella Fault; CMF—Cinque-Miglia Fault; CaSF-Cassino South Fault; VMF-Velino-Magnola Fault; TMF-Tre Monti Fault. P-Locations of photographs in Fig. 5. (c) Simplified geological map of Lazio-Abruzzo showing Quaternary hanging wall basins to normal faults. (d) Fault map overlain on a $1 \mathrm{~km}^{2}$ pixel, digital elevation model.

measured fault-specific seismic cycle durations for large magnitude events ( $>$ Ms 6.0) derived from palaeoseismology are a few thousand years or less. Our goal is to establish the nature of spatial throw-rate variation, and use this information to help map seismic hazards. Cowie and Roberts (2001) provided a brief examination of this same fault array but concluded that they had not included all the active faults so that their results could only be considered to 
be preliminary. Roberts et al. (2002) illustrated some aspects of the deformation in the Lazio-Abruzzo Apennines, but this is the first time that the entire database, including data for what we think are all or most of the active faults in the region, has been presented. In a second paper, Roberts et al. (2003) attempt to (1) map the frequency and intensity of seismic shaking events in the Lazio-Abruzzo Apennines implied by the throw-rate database presented herein, and (2) validate their results through comparison of the measured throw-rates with those predicted by the method of Cowie and Roberts (2001), and through comparison with the measured historical record of seismic shaking for 14 medieval towns in Lazio-Abruzzo.

The most prominent features of expected throw-rate variation implied by Cowie and Roberts (2001) are described below (Fig. 1). Scaling relationships between the lengths and displacements on faults imply that faults that form part of a linked/interacting array must grow at a rate that produces a $d / L$ ratio for the linked/interacting array that is in the range 0.001-0.1 (Schlische et al., 1996). The two orders of magnitude variation in $d / L$ (Fig. 1a) is small compared with the eight orders of magnitude in fault length considered so that small and large faults are essentially selfsimilar (e.g. McLeod et al., 2000). If large faults develop through the growth, interaction and linkage of small faults, as is implicit in most models of fault growth (Walsh and Watterson, 1988; Dawers et al., 1993; Anders and Schlische, 1994; Cartwright et al., 1995; Gawthorpe et al., 1997; Willemse, 1997; Nicol et al., 1997; Cowie, 1998; Morley, 1999; Gupta and Scholz, 2000; Contreras et al., 2000), then simple geometrical reasoning shows that faults towards the centre of an array must have higher throw-rates than those close to the ends in order for the central part of the larger fault to develop the largest throw (Cowie and Roberts, 2001) (Fig. 1b-e). Such a pattern develops through time, with an increase in throw-rate on centrally located faults-presumably following the initiation of significant fault interaction or linkage-relative to those faults that are located more distally along strike (Cowie, 1998; Contreras et al., 2000; McLeod et al., 2000; Mansfield and Cartwright, 2001). Central faults in soft-linked arrays should exhibit steeper throw gradients and throw-rate gradients, and higher values for their throw/length ratios (Fig. 1d). If we assume no spatial variation in earthquake frequency-magnitude relationships along the array, and examine time periods that are long enough to contain numerous seismic cycles, central faults must rupture more often during earthquakes of a given magnitude (Fig. 1f).

The key point is the long time periods needed for the above patterns of deformation to emerge. We argue that it will not be possible to test the above using instrumental seismicity records or geodetic measurements in central Italy. This is because such datasets cover time periods of less than a century yet earthquake recurrence intervals measured using palaeoseismological studies are ca. 500-> 3000 years (Giraudi and Frezzotti, 1995; Michetti et al., 1996; Pantosti et al., 1996; Galadini et al., 1997a,b). These long recurrence intervals are consistent with the fact that extension rates across the whole Apennines are very low, in the range of only a few millimetres per year (Westaway, 1992; Hunstad and England, 1999; D’Agostino et al., 2001a). Even the long historical earthquake record for central Italy, which may be complete for events $\geq$ Ms 5.5 for the last ca. 800 years (see Galadini and Galli (2000) for a review; Postpischl, 1985), is too short to constrain spatial and temporal variations in the deformation that emerge over the time span of many fault-specific seismic cycles (e.g. Cowie, 1998). In addition, (1) only one large magnitude earthquake ( $>$ Ms 6.0) is reasonably constrained for the region (the 13th January 1915 Ms 6.9-7.0 event; Margottini and Screpanti, 1988), and (2) GPS geodetic data are available traversing the entire width of the Apennines showing a $6 \pm 2 \mathrm{~mm} / \mathrm{yr}$ extension rate (D'Agostino et al., 2001a), but the data do not cover the entire along-strike extent of the extending region. Thus, the method that we adopt is to use measurements of the offset geology, specifically features formed at the end of the last glaciation (16-18 ka), to gain deformation rates averaged over time periods that will contain many seismic cycles (Section 3). Normal faults in this region produce surface faulting during earthquakes $\geq$ Ms 5.5 (Michetti et al., 2002a) and therefore generate a clear signature in the local landscape and Quaternary stratigraphy. These features provide a record of the long-term, multi-seismic cycle pattern of deformation and allow us to test whether the features shown in Fig. 1 exist.

The geology of central Italy is ideal for describing the geometry, kinematics and rates of deformation: (1) we can show that the length of the fault system is relatively wellconstrained (ca. $155 \mathrm{~km}$ ) and the amount and rates of extension associated with active faults appear to die out in both directions along strike (we justify this further below); (2) faults in the region are well-exposed, mainly on Mesozoic limestone mountain fronts with similar lithologies allowing comparison of geomorphic features between faults; (3) a variety of published geological maps are sufficient to constrain serial cross-sections and thus fault throw gradients; (4) the region contained mountain glaciers that retreated at ca. $16-18 \mathrm{ka}$, providing a regional marker of known age (glaciation-related sediments and periglacial slopes) that has now been offset by fault scarps-spatial variations in the throws across scarps reveal throw-rate gradients averaged over 16-18 kyrs; (5) a number of published palaeoseismological trench site investigations of Holocene-Recent sediments can be used to locally validate throw-rate values from scarp morphology observations; (6) the historical record of earthquakes has illustrated the relationships between surface faulting, earthquake magnitudes and macroseismic intensities (MCS scale). References illustrating all the above points are given later in the text. There is some disagreement over the positions of active faults (see D'Agostino et al., 2001a) so our fieldwork has in 
part focused on this problem. The above datasets and our own fieldwork allow us to test whether the patterns of slip implied by Fig. 1 exist in the Lazio-Abruzzo Apennines (Sections 4-7).

\section{Regional tectonics and geology}

The Lazio-Abruzzo Apennines is a region of extending continental crust positioned within the zone of convergence between the Eurasian and African Plates (Anderson and Jackson, 1987; Jolivet et al., 1998; Doglioni, 1993) (Fig. 2). Northward motion of the African plate through the late Mesozoic-Recent has led to subduction of the Tethyan ocean crust and collision of fragments of continental crust, which now form the northern margins of the Mediterranean Sea. Thrusting continues to the present day on the Adriatic side of the Apennines, but in general, NE-directed thrusting in the inner part of central Italy ceased in the Pliocene (Patacca et al., 1990). Subsequently, extension began, with rocks as old as at least ca. 2.5 Ma infilling extensional basins in the Lazio-Abruzzo Apennines (Cavinato and De Celles, 1999). The Rieti and Terni extensional basins were at sea level in the early Pleistocene, but have since been uplifted (Gliozzi and Mazzini, 1998). D'Agostino et al. (2001b) review the evidence for widespread Quaternary surface uplift. They point out that an early Pleistocene shoreline exposed for a distance of around $100 \mathrm{~km}$ on the western edge of the Apennines has been uplifted by a long wavelength uplift to elevations of 200-400 m. The uplifted topography is thought to be supported dynamically by mantle convection, enabled by an effective elastic thickness of ca. $4 \mathrm{~km}$. Uplift also caused incision of the drainage. The high topography of the NW-SW-trending thrust belt of the central Apennines has been dissected by a series of active normal faults locally striking parallel to the Apennine Mountains and the thrust belt, although in places the normal faults strike at high angles to, and offset, major thrusts (Fig. 2). Focal mechanisms and borehole breakout data indicate a general NE-SW extension (Montone et al., 1999).

The normal fault system we examine lies in a region that contains Miocene foredeep sediments and Mesozoic platform carbonates forming high topography (CNR, 1986, 1990). Small Late Pliocene/Quaternary continental basins occur in the hanging walls of some active normal faults. The hanging walls of others are simply marked by valleys where syn-rift sediments have either never accumulated or have been stripped-out due to river incision. The record of large magnitude earthquakes in the region spans over 1000 years with many written reports of damaging earthquakes that were most-likely normal faulting events located in the Lazio-Abruzzo Apennines (Postpischl, 1985; Boschi et al., 1995). However, focal mechanisms for large magnitude events are lacking (Anderson and Jackson, 1987; Montone et al., 1999), so study of known earthquakes is unlikely to produce a robust velocity field for the extension. GPS studies have documented an extension rate of $6 \pm 2 \mathrm{~mm} / \mathrm{yr}$ in a thin-corridor crossing Lazio-Abruzzo (D'Agostino et al., 2001a; see Hunstad and England (1999) for an earlier study using triangulation). D'Agostino et al. (2001a) also compared the GPS extension rate with an active fault map published by Galadini and Galli (2000). They concluded that the inventory of faults on this map must be incomplete because significant extension was measured across an area where few active faults were reported. However, other authors provide alternative active fault maps that do show faults in the area in question (e.g. Bosi, 1975; Vittori, 1994; Vezzani and Ghisetti, 1998; Vittori et al., 1998; Michetti et al., 2000b). Hence, to test existing data on the locations of active faults and present new observations, we have turned to the geology to constrain the geometry, kinematics and rates of extension associated with the fault system in the Lazio-Abruzzo Apennines.

\section{Methodology}

\subsection{Fault map traces}

The traces of all major normal faults in the LazioAbruzzo Apennines were identified using published $1: 100,000,1: 250,000,1: 500,000$ and other geological maps (e.g. Carta Geologica d'Italia, 1939, 1955, 1963, 1966, 1967, 1970a,b, 1987a,b, 1990, 1992; CNR, 1986, 1990; Vezzani and Ghisetti, 1998). These fault maps were then checked during field mapping (Figs. 2 and 3). It is difficult to quantify the error associated with the fault traces because vegetation obscures the actual faults in some locations so geomorphic features and published geological maps (with their own inherent errors) are used to infer the traces of the faults. Elsewhere we have located the exposed fault map traces to within a few metres using a hand-held GPS. Thus, the traces of faults in Fig. 2 are probably within less than ca. 100-200 $\mathrm{m}$ of their actual positions with regard to distance perpendicular to fault strike (i.e. the error is smaller than the thickness of the lines shown in Fig. 2). The main problem is identifying fault lengths. The faults appear to be segmented at a length scale of ca. 5-15 km with smallscale en échelon fault overlaps (transfer zones or relay ramps) separating faults (Fig. 3). The structure of these fault overlaps is generally poorly exposed due to vegetation cover. Thus, at the outset, the lengths of faults were unclear, yet this is one of the important data inputs needed to examine how slip-rates vary with distance along faults, and test the hypothesis of Cowie and Roberts (2001). However, we noted that the topographic variations along faults occur over larger distances $(20-40 \mathrm{~km})$, suggesting that at least some faults are longer than $5-15 \mathrm{~km}$. Additionally, Quaternary basins exist in the hanging walls of some faults, and these are generally of the same length scale as the topographic variations (Fig. 2). We decided that fault lengths could not be established with any certainty using 


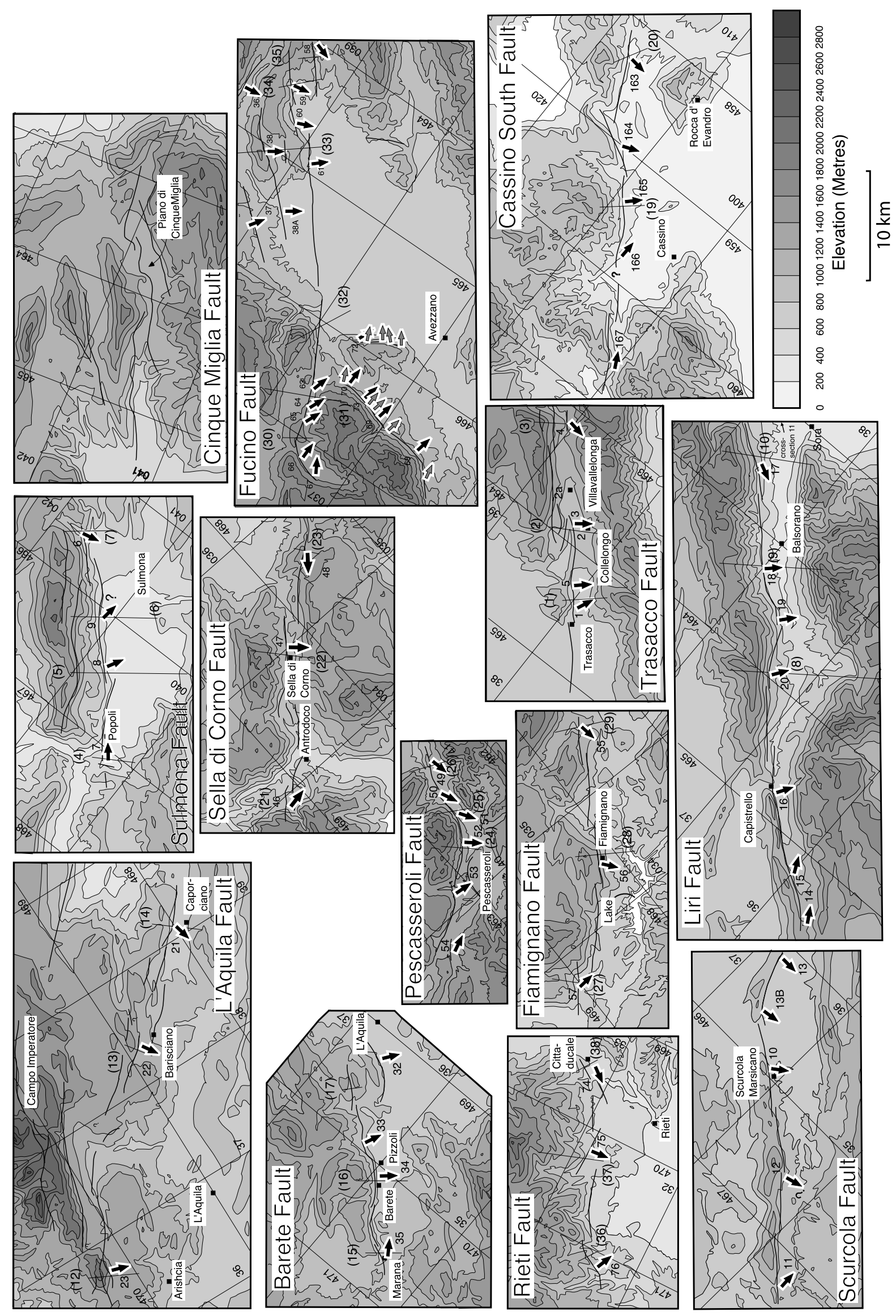


only map trace data, due to uncertainty concerning the significance of these fault overlaps. We collected throw, throw-rate and kinematic information to help us verify fault lengths as described below.

\subsection{Throw profiles}

Throw profiles have been constructed along most of the major faults within the region by drawing a number of crosssections across each major fault using published 1:100,000 and other topographic and geological maps (Fig. 4). The goal was to recognise places where throws decreased to zero to establish fault lengths. We have used a number of different horizons in our cross-section construction (see Fig. 4) but they all share the property of being pre-rift horizons, and thus record the total extension across the structures. The cross-section transects are several kilometres in length, in places crossing several closely-spaced faults. Errors on throws are variable (Fig. 4), and difficult to quantify due to the subjective nature of the structural style chosen when extrapolating above and below ground level during crosssection construction. However, an attempt has been made to use structural styles that are consistent with those exposed in cliff sections across well-exposed faults (see Fig. 5). There is little evidence for folding of horizons as they approach faults (Fig. 5a) so we adopted this structural style in our cross-sections. It is thought that errors in throw values are in most cases $< \pm 200 \mathrm{~m}$, which is sufficient for our purposes.

\subsection{Fault slip directions}

Striations, corrugations and fault plane orientations were measured at a number of localities along each fault in order to constrain the kinematics of the faulting and hence fault lengths (Fig. 6). Study of normal faults elsewhere has shown that slip-directions can help define fault lengths because they vary with throw and distance, converging towards the fault hanging walls (Roberts, 1996; Michetti et al., 2002a; Roberts and Ganas, 2000). Throw gradients on faults produce stretching of the ground surface along strike so slip-directions converge towards the hanging wall to accommodate this stretching. Fault lengths should therefore be reflected in the length-scale of the converging patterns of fault slip (see Roberts and Ganas (2000) for a full explanation of this methodology). To recognise the above patterns, we measured the strike and dip of faults and the plunge and plunge directions of lineations on fault planes close to the ends and centres of the normal faults indicated by the throw and fault trace analysis described above. We measured both the main fault planes (including variations due to the corrugated nature of the planes) and smaller minor fault surfaces in both the hanging wall and footwall where available. These 6824 measurements were made at 86 localities. Localities are small $\left(<\right.$ ca. $\left.400 \mathrm{~m}^{2}\right)$ compared with the length of the faults. We measured all fault surfaces that intersected horizontal transect lines across exposures. Positions of localities were recorded using a hand-held GPS receiver and these geographic coordinates were used to help establish fault lengths (Table 1). The UTM coordinates of the localities were measured in 1998 and are thus within about $100 \mathrm{~m}$ of the actual position. Mean values for the slipdirection were calculated for each site using Fisher statistics in standard stereographic projection computer packages. The errors on the mean values for each site are variable, but the mean error is about $\pm 5^{\circ}$ at the $99 \%$ confidence level (see Table 1 and Fig. 6).

\subsection{Deformation rates}

Rates of deformation and their spatial variation have been constrained using published palaeoseismological results, and new geomorphic observations of offset glacial features (Table 1).

The palaeoseismological trench site data provide radiometric dates for soils (mostly younger than ca. 4000 years B.P.) offset by fault-slip (see references in Table 1). The data allow derivation of fault throw-rates. Errors on the radiometric dates are generally a few hundred years so errors in throw-rate values introduced in this way are probably smaller than a few tenths of a millimetre per year. Errors may be introduced because such throw-rates are averages over time periods of a few thousand years but throw-rates may fluctuate over longer time periods due to temporal earthquake clustering. The errors in throw-rate are difficult to quantify in this case, but in most instances the throw-rates can be checked against throw-rates for longer time periods such as those derived from offset glacial features. As described below, these provide averages over longer time periods (18 kyrs).

Rates of slip averaged over 18 kyrs were derived using published literature and throws associated with fault scarps offsetting slopes and deposits associated with the demise of the last glaciation (Figs. 5 and 7) (Table 1). The high topography of the Lazio-Abruzzo Apennines (up to $2900 \mathrm{~m}$; see Fig. 2) contained mountain valley glaciers during the last glaciation revealed by the presence of moraines and glacial landforms (Giraudi and Frezzotti, 1997). Periglacial conditions existed in areas not covered by ice. High erosion-sedimentation rates produced alluvial fans emanating from mountain valleys and slopes that were icefree. Sedimentation and erosion rates outpaced fault throwrates evidenced by hanging wall fan surfaces and colluvial

Fig. 3. Detailed topographic and fault maps for a representative set of active faults in Lazio-Abruzzo. Numbers next to the black arrows show the localities on Figs. 2 and 6, and in Table 1. Lines with numbers in brackets show locations of cross-sections in Fig. 4. Slanted numbers on east-west and north-south grid lines are UTM coordinates. Black arrows show fault-slip directions from Fig. 6. Grey arrows from Morewood and Roberts (2000). 


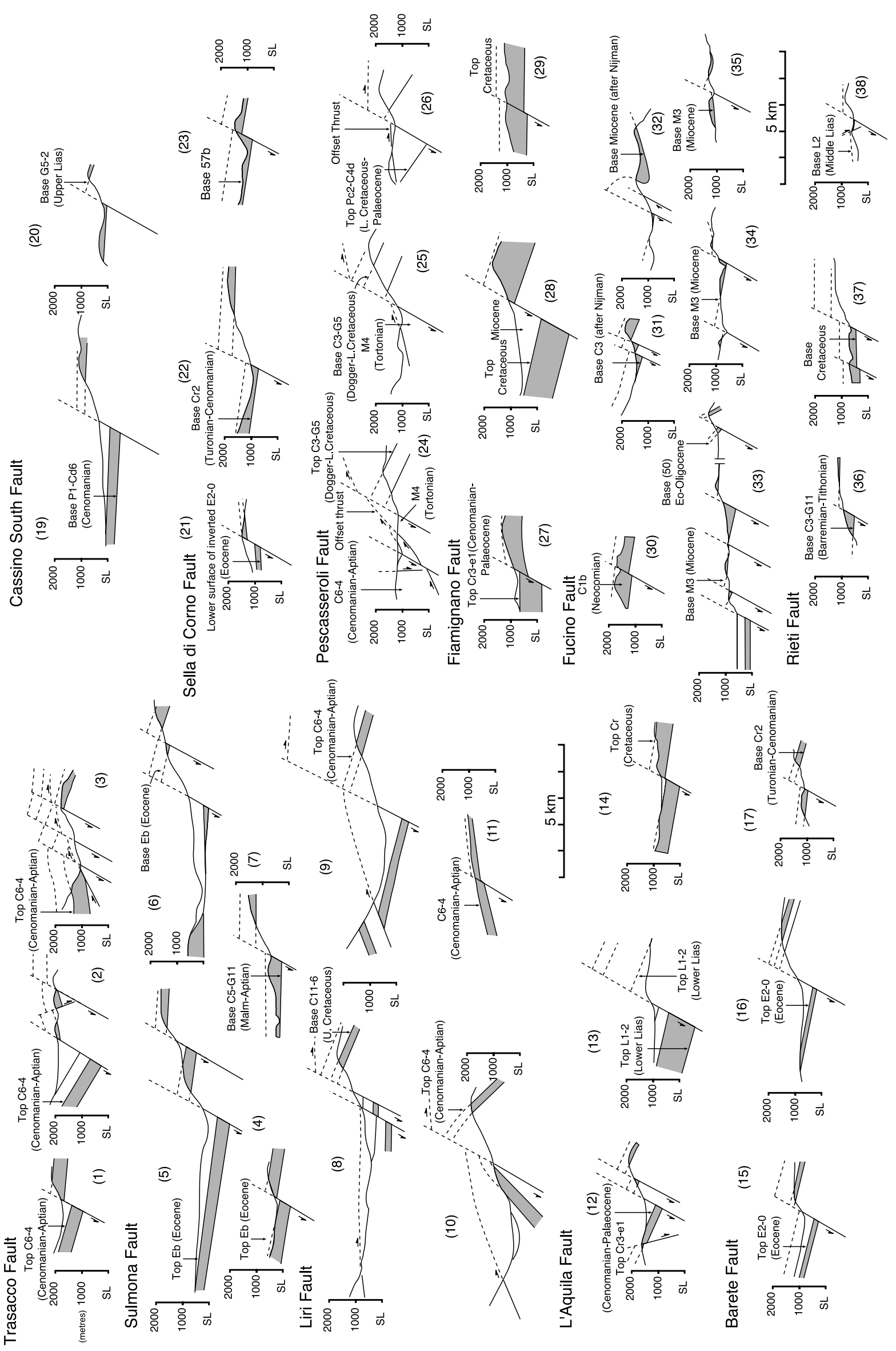


slopes associated with active faults that are graded to the slope of the footwall bedrock slope. At some point during the demise of the glaciation, the recovery of temperate vegetation stabilised the fan surfaces and mountain slopes, and stream discharges decreased. The result is smooth hillsides that are typical of former periglacial processes. The fan surfaces, bedrock slopes and moraines are covered in many places by a thin (ca. $0.5-1.0 \mathrm{~m}$ ), organic- and in places volcanic-rich soil (e.g. Giraudi, 1995a), deposited during and after the demise of the glaciation (Giraudi and Frezzotti (1997) and references in Table 1). Elsewhere, the demise of the glaciation is recorded by frontal moraines that are overlain by fluvial outwash or meltwater lake deposits (Giraudi and Frezzotti, 1986). Palaeo-vegetation and volcanic ash from nearby volcanic eruptions provides datable material in these deposits. An extensive database of radiocarbon dates and tephrachronology reveal the absolute and relative ages of the above-mentioned glaciation-related deposits and slopes (Giraudi and Frezzotti (1986) and references in Table 1). They also allow correlation with climatic records from Tyrrhenian sea cores and other oceanic and continental records. The last major glacial retreat phase occurred at ca. $18-16 \mathrm{ka}$ (Giraudi and Frezzotti, 1986; Allen et al., 1999); throughout this paper we use a value of $18 \mathrm{ka}$. This time corresponds with a shift in $\delta^{18} \mathrm{O}$ values from Tyrrhenian sea cores and cores from other marine areas, verifying a major climatic change. Several minor glacial advances occurred after $18 \mathrm{ka}$, but these events had a relatively minor effect on the geomorphology (Giraudi and Frezzotti, 1997). Today, normal fault bedrock scarps offset the glaciation-related features (see observations and references in Table 1). In places, the scarps expose Mesozoic bedrock in their footwalls and generally show very little degradation.

The throws associated with these scarps are a measure of the throw-rate averaged over the age of the slope or deposit (Fig. 7). Hence an $18 \mathrm{ka}$ scarp that has a throw of $18 \mathrm{~m}$ yields a throw-rate of $1 \mathrm{~mm} / \mathrm{yr}$. If the age is $16 \mathrm{ka}$ then the throw-rate is $1.125 \mathrm{~mm} / \mathrm{yr}$. Errors on throw-rates introduced by uncertainty about slope ages are thus less than a few tenths of a millimetre per year. Also, the throws associated with scarps appear spatially-variable by up to about $20 \%$ at some localities so errors accrue in measured throws across scarps. Thus, for a scarp stated to have $18 \mathrm{~m}$ throw offsetting an $18 \mathrm{ka}$ slope, the actual throw could be about 21.6$14.4 \mathrm{~m}$, and the implied throw-rate is therefore $1 \pm 0.2 \mathrm{~mm} /$ yr. If a scarp is stated to have $18 \mathrm{~m}$ throw and the slope formed at $16 \mathrm{ka}$ the actual throw could be 21.6-14.4 m, and implied the throw-rate is therefore $1.125 \pm 0.225 \mathrm{~mm} / \mathrm{yr}$. As a result, we propagate an error of $\pm 0.2 \mathrm{~mm} / \mathrm{yr}$ for throwrate for each locality throughout the rest of the paper although the actual error will be smaller than this if the scarps have throws less than $18 \mathrm{~m}$.

A further source of error is the possibility that we may not have recognised some scarps leading us to underestimate deformation rates. However, the scarps have been intensively studied (see references in Table 1), generally exist high on hillsides, and can be seen from several kilometres away. We think it unlikely that we and other workers have missed scarps with throws more than ca. $4 \mathrm{~m}$ high. If we have missed a 4-m-scarp then we will have underestimated the throw-rate at that locality by ca. $0.2 \mathrm{~mm} /$ yr assuming $18 \mathrm{ka}$ for the demise of the glaciation.

Also, note that we have found that normal faults in the SW of the region have clear and measurable cumulative throws of pre-rift strata of several hundred metres or more, but appear to have no post-glacial scarps associated with them. This area is characterised by moderate-low seismicity with no recorded events with MCS scale macroseismic intensities greater than VIII or magnitudes $\mathrm{M} \geq 5.0$ (GNDT, 2000). There is also no evidence for late Quaternary offset associated with large magnitude surface faulting events from palaeoseismology. We show these faults on Fig. 2, but omit them from later analysis. Presumably, these faults are either inactive or have slipped so slowly since the last glaciation $(<\mathrm{ca} .0 .2 \mathrm{~mm} / \mathrm{yr}$ throwrate) that sedimentation and erosion rates have been high enough to destroy the scarps.

We stress that the faulted slopes and glacial surfaces are not dated in all the places we have studied despite the extensive literature on this subject (Table 1). Thus, our throw-rate estimates may be inaccurate if we have incorrectly identified the slope ages. There are two main ways that we may have incorrectly identified the slope age. First, the assumption that the end of the last glacial maximum (ca. $18 \mathrm{ka}$ ) set the slopes may be in error. However, we note that cosmogenic isotope exposure dating of bedrock scarps in southern Greece reveal that they formed through accumulation of slip since the end of the last glacial maximum through repeated metre-sized slip-events, presumably during large magnitude earthquakes (Ms $>6.0$ ) (Benedetti et al., 2002). Indeed, even before this cosmogenic isotope dating, the ca. $18 \mathrm{ka}$ age was a common assumption in studies of fault scarps around the Mediterranean region (Westaway et al., 1989; Armijo et al., 1992; Piccardi et al., 1999; Galadini and Galli, 2000; Morewood and Roberts, 2000), because it was and still is difficult to conceive of a different age for their formation. Where faults have cumulative throws of several kilometres yet have scarps only a few metres high it is clear that the scarps record only a small part of the extension; thus, the scarps must offset slopes that are young compared with the

Fig. 4. Cross-sections across active faults in Lazio-Abruzzo. All labelled geological strata are part of the pre-rift stratigraphy and thus record the total throw across the faults. Cross-sections are located in Fig. 3. Cross-sections were constructed from the geological data on published geological maps (see text for references; C3 and Miocene Bases of Fucino Fault after Nijman, 1971); the abbreviated stratigraphic names are from these maps. 


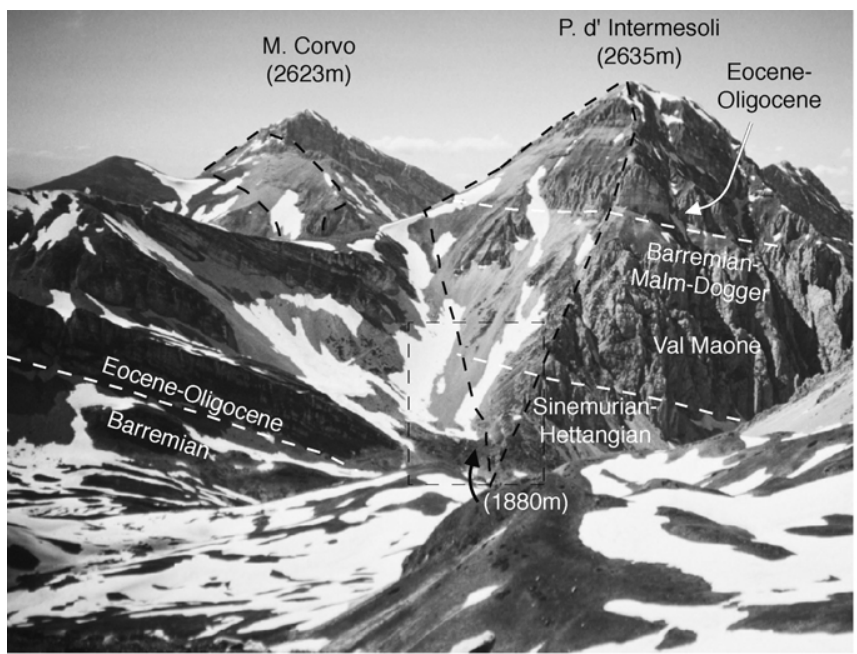

(a)

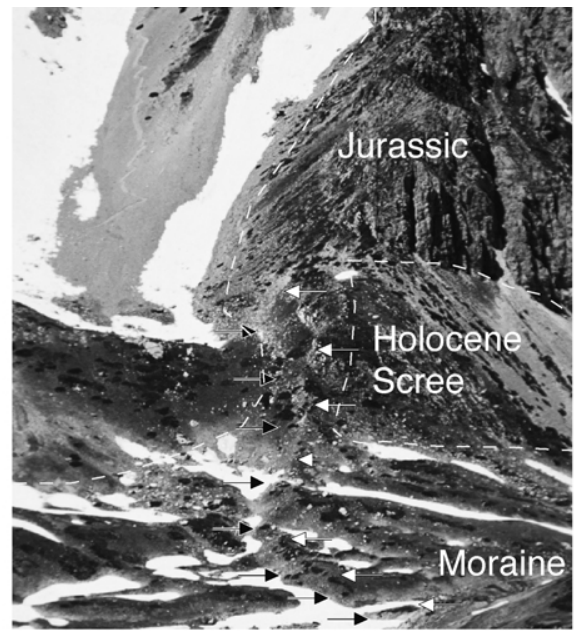

(b)

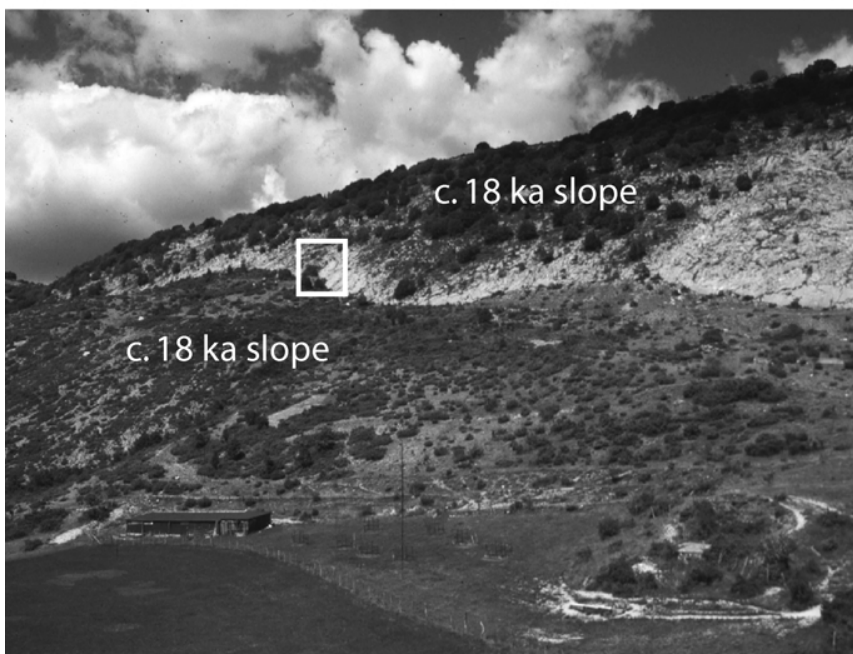

(c)

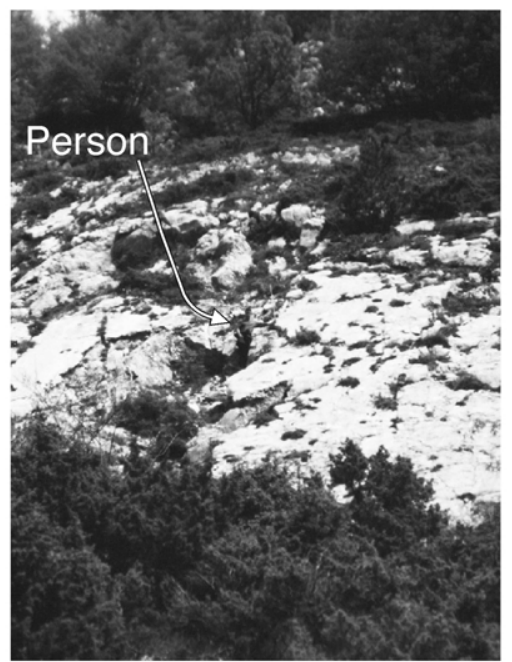

(d)
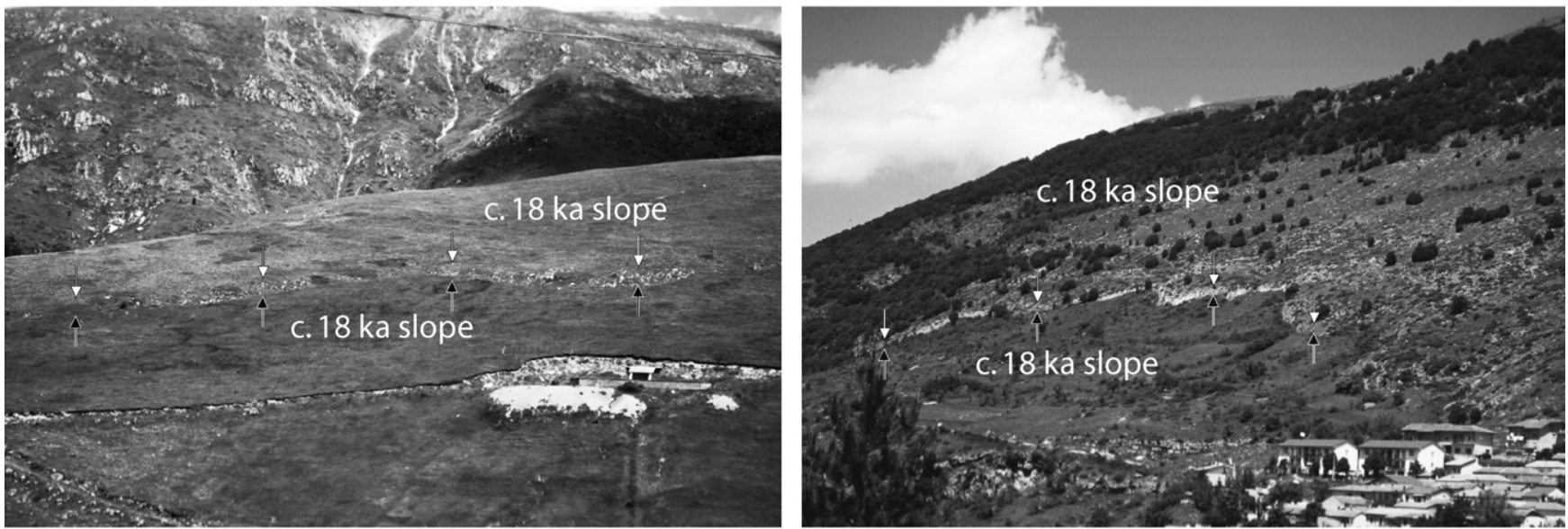

(e)

(f)

Fig. 5. Photographs of active normal faults in Lazio-Abruzzo. (a) The Campo Imperatore-Tre Selle Fault in the Val Maone during May partial snow-cover. Polygons in black dashed lines indicate the positions of the main fault plane. The base of the Eo-Oligocene is offset vertically by ca. $600-700 \mathrm{~m}$. Box locates (b). (b) Close-up of the Campo Imperatore-Tre Selle Fault in the Val Maone where moraines from the last glaciation (glacial maximum ca. 18 ka) are offset by a scarp (arrows) a few metres high (see Giraudi and Frezzotti (1995) for details). (c) View of the scarp on the Fiamignano Fault offsetting a periglacial slope. Note how the slope angles are very similar in the hanging wall and footwall allowing measurement of throw since the last glaciation (see Fig. 7). Box locates (d). (d) Close-up of the scarp on the Fiamignano Fault with person for scale. The periglacial slope is offset vertically by about 15-18 m. (e) View of one of the multiple scarps (arrows) associated with what we term the Campo Imperatore Fault (see Table 1). The periglacial slope is offset by $2-3 \mathrm{~m}$. (f) View of one of the multiple scarps on what we call the Fucino Fault near San Sebastiano (see Table 1). The periglacial slope is offset by 5-7 m. 
extension. Slope formation is dominated by high erosion climatic periods that, in the Mediterranean, have been linked to glacial episodes in the Quaternary. Such glaciations culminated at about 18,140 and $260 \mathrm{ka}$ in the Mediterranean region revealed by a variety of palaeoclimate studies (e.g. Tzedakis et al., 1997). With scarp heights of only a few metres or tens of metres, only the 18 ka age can be reconciled with the extension rates of a few millimetres per year revealed by moment release studies and geodesy (Westaway, 1992; Hunstad and England, 1999; D'Agostino et al., 2001a); the older ages would imply total extension rates across the Apennines of fractions of a millimetre per year, an order of magnitude less than the probable rate, and would be inconsistent with the results of cosmogenic isotopic dating of similar scarps. The fact that there are numerous dates on slopes that are about $18 \mathrm{ka}$ and none that we are aware of that are $140 \mathrm{ka}$ or older (see references in Table 1) supports the interpretation that we and others make concerning slope ages.

Some workers have claimed that the presence of bedrock scarps may not necessarily prove activity since the last glaciation, suggesting that they form due to "exhumation phenomena driven by differential erodibility of carbonate bedrock and Miocene Flysch" (Galadini, 1999). We doubt this is correct. During our study of the scarps we were able to identify places where post-glacial stream incision or deposition and/or slope wasting phenomena have altered scarp heights and were thus careful to avoid such locations. Also, as described below, the scarp heights vary spatially in the same way as cumulative throws and slip-directions derived from fault-plane striation data. The scarp height minima coincide geographically with cumulative throw minima and places where slip directions change by $90^{\circ}$ between neighbouring faults. We doubt this is a coincidence and interpret the scarps as signs of surface fault slip rather than erosion-related exhumation phenomena. This is supported by the fact that field observations following $M>5.5$ earthquakes in Italy show that surface slip occurs and is preserved along such scarps (Michetti et al., 2000a).

\section{Results and interpretation}

\subsection{The lengths and positions of major normal faults}

The throws we have measured across the normal faults vary over distances of about $20-40 \mathrm{~km}$, showing clear maxima and minima (Fig. 8). We suggest that the minima indicate the lateral terminations of the major faults. This interpretation is supported by the fault-slip direction data, which show converging patterns of slip along our interpreted major faults and large (ca. $90^{\circ}$ or more) variations in slip direction between neighbouring major faults. The converging slip-directions support the throw patterns because they indicate patterns of along-strike stretching of the ground in a manner that is consistent with the throw variations. Our measured slip-directions agree with other published accounts (e.g. Galadini, 1999; Piccardi et al., 1999; Morewood and Roberts, 2000), but cover a larger area and more faults than existing studies. The throw-rates we have measured also vary over distances of about $20-40 \mathrm{~km}$, showing maxima and minima that coincide geographically with the throw maxima and minima; minima in throw and throw-rates coincide with places where large (ca. $90^{\circ}$ or more) variations in slipdirection exist between neighbouring major faults (Fig. 8). Thus, the throw-rates are also consistent with our interpretation of the lengths of major faults. In general, the faults appear to be characterised by symmetrical throw and throwrate profiles. We stress that the slip-direction, throw and throw-rate values are derived from independent data sources. There are also other active faults on the edge of the area we study which we have not included in our analysis due to a lack of data. These are the Montereale and Laga Faults (Fig. 2), which are shown by GNDT (2000), Blumetti (1995) and references therein. The throw-rates and throws on these faults have not been measured by us, but as shown below, this makes little difference to our overall conclusions.

Smaller scale en échelon faults overlap between ca. 5 and $15 \mathrm{~km}$ long faults do not always coincide with our measured throw or throw-rate minima or regions where slipdirections change by ca. $90^{\circ}$. Thus, we do not interpret them to be the ends of the major faults. We acknowledge that these en échelon overlaps clearly demarcate small, but nonetheless separate faults at the surface. However, we suggest that these small faults are working together in groups to produce the throw patterns-perhaps through hard-linkage at depth or through elastic soft-linkage-and form small parts (segments; fragments) of larger, major faults.

Our analysis reveals the presence of 21 major normal faults in the Lazio-Abruzzo Apennines plus two others mentioned by Blumetti (1995). The faults measured at localities 72, 73 and 68-70 (Fig. 2) (Campofelice, Tre Monti and Velino-Magnola Faults) are probably not major faults as we have defined them above: (1) they do not show converging patterns of slip; (2) they have different strikes

Fig. 6. Lower hemisphere stereographic projections showing the orientations of striations and corrugations (black squares) and poles to fault planes (white squares). White circles show the mean slip-vector orientations. Locality numbers refer to Figs. 2 and 3 and Table 1 . 'All Lines' means all measured faults and lineations from the footwall and hanging wall minor fault arrays together with the main fault plane have been plotted. 'Fw Lines' means only faults and lineations from the footwall minor fault array have been plotted. 'Hw Lines' means only faults and lineations from the hanging wall minor fault array have been plotted. 

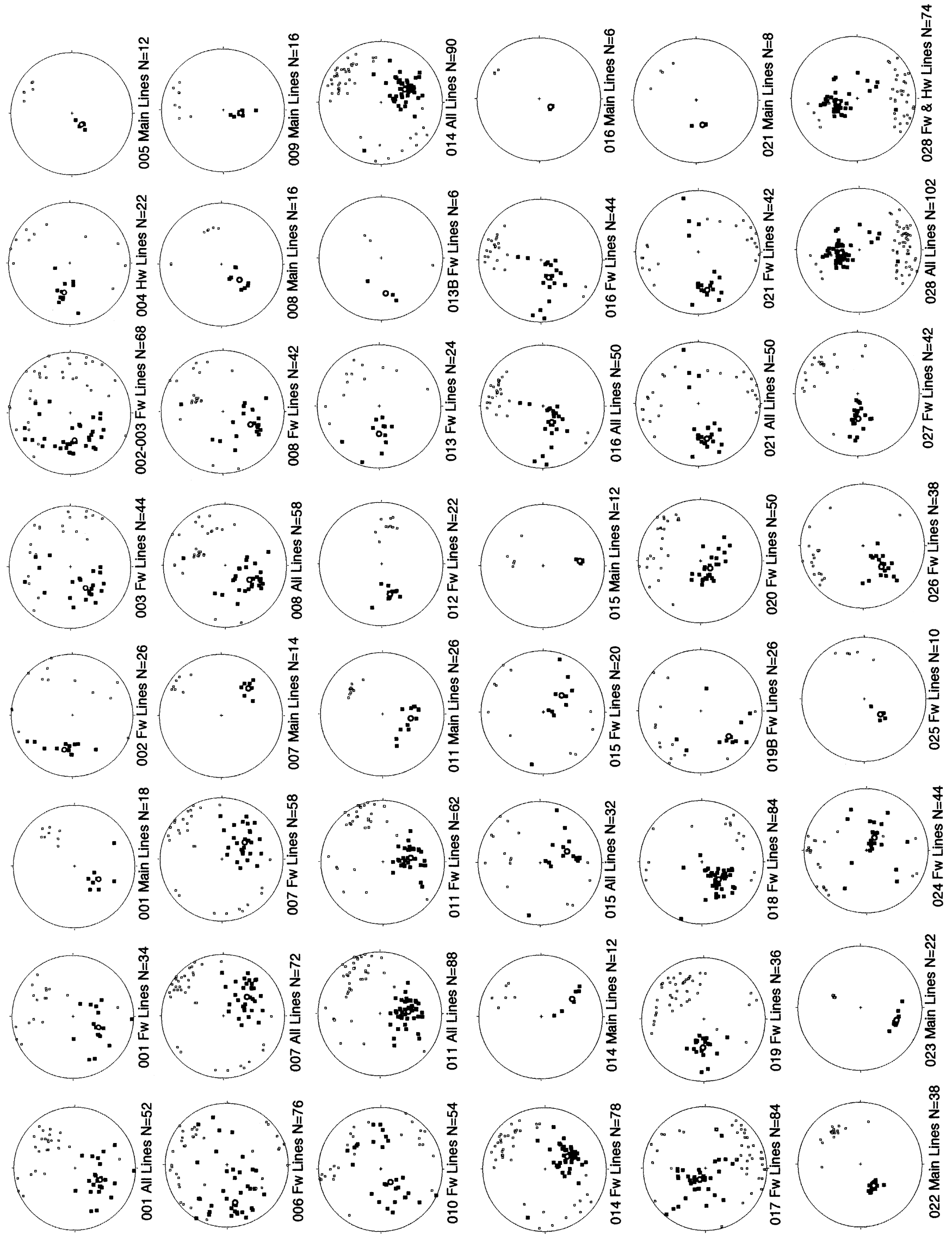

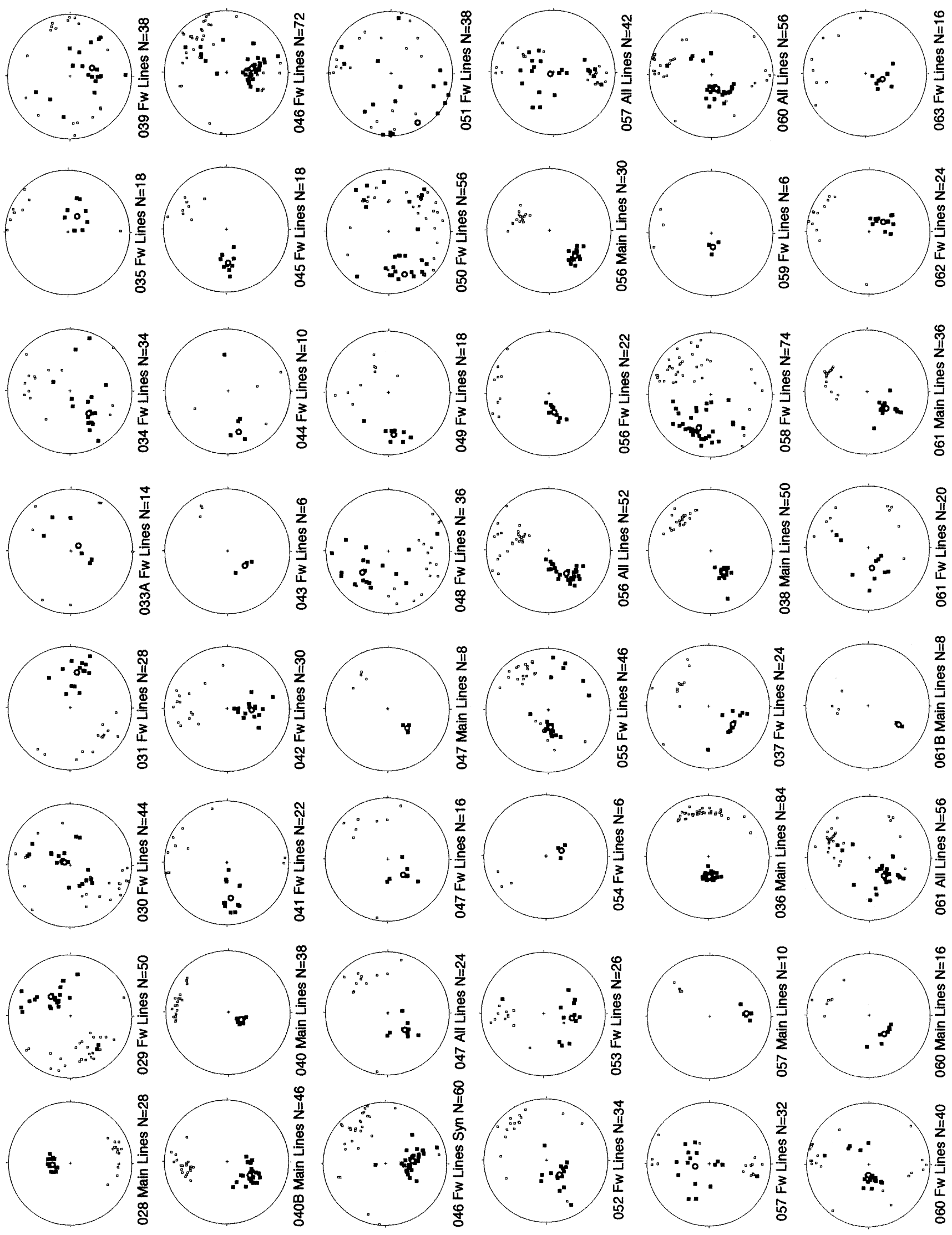

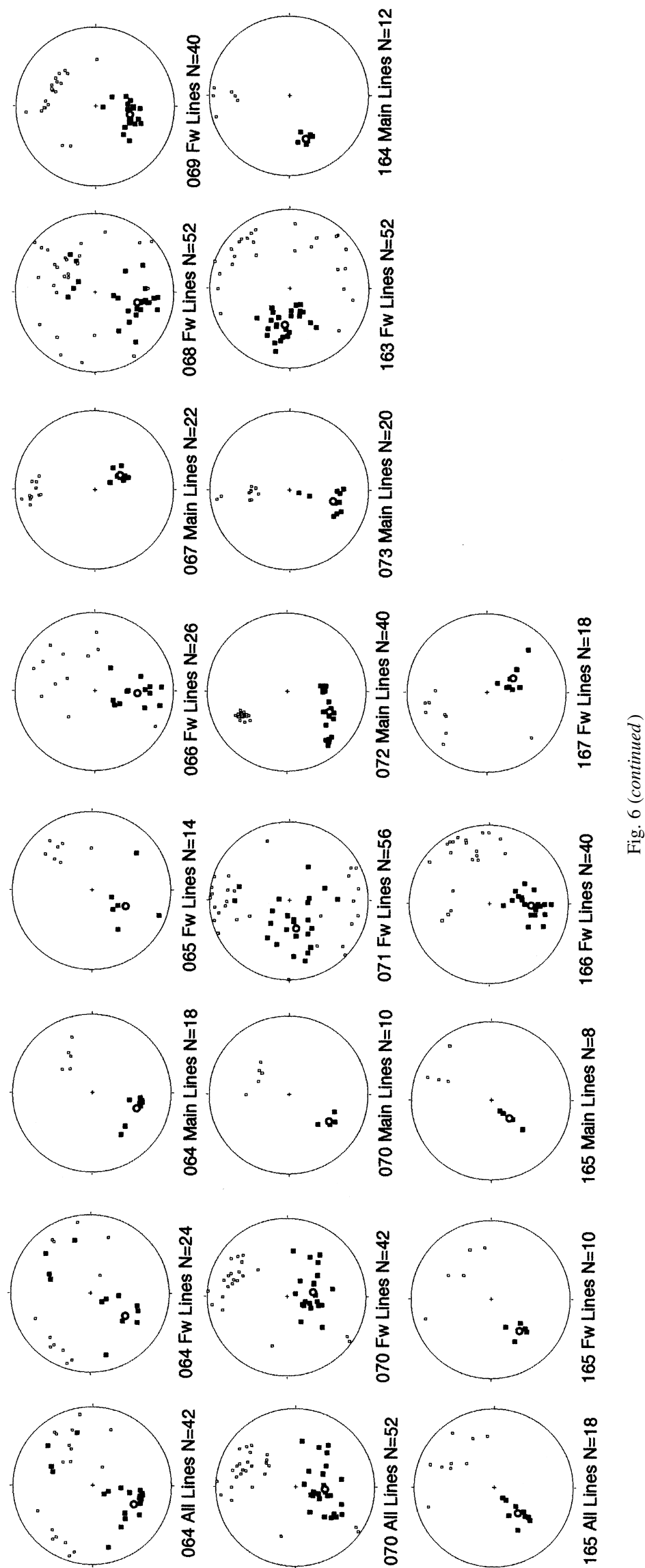
Table 1

Database of throw, throw-rate and kinematic data for active normal faults in the Lazio-Abruzzo Apennines

\begin{tabular}{|c|c|c|c|c|c|c|c|c|c|c|c|c|}
\hline Fault name & $\begin{array}{l}\text { Locality } \\
\text { number }\end{array}$ & $\begin{array}{l}\text { Nearest town or } \\
\text { geomorphic } \\
\text { feature of note }\end{array}$ & $\begin{array}{l}\mathrm{X} \text { UTM } \\
\text { value }\end{array}$ & $\begin{array}{l}\text { Y UTM } \\
\text { value }\end{array}$ & $\begin{array}{l}\text { Slip direction } \\
\text { mean in degrees }\end{array}$ & $\begin{array}{l}\text { Plunge of } \\
\text { slip vector }\end{array}$ & $\begin{array}{l}\text { Slip vector } 99 \% \\
\text { confidence cone }\end{array}$ & $\begin{array}{l}\text { Total throw of } \\
\text { pre-rift strata } \\
\text { (metres) } \pm<\text { ca. } \\
200 \mathrm{~m}\end{array}$ & $\begin{array}{l}\text { Notes on offset geomorphic features and palaeoseismological } \\
\text { sites used to constrain throw rates }\end{array}$ & $\begin{array}{l}\text { Throw rate } \\
(\mathrm{mm} / \mathrm{yr}) \\
\pm<0.2 \mathrm{~mm} / \mathrm{yr}\end{array}$ & $\begin{array}{l}\text { Distance along } \\
\text { fault }(\mathrm{km})\end{array}$ & $\begin{array}{l}\text { Distance from } \\
\text { fault center } \\
(\mathrm{km})\end{array}$ \\
\hline \multirow[t]{5}{*}{ Trasacco } & 001 All & Trasacco & 379962 & 4644269 & 204 & 51 & 12 & 700 & $\begin{array}{l}\text { Quarry, so no scarp observed. Trenches and geomorphology } \\
\text { along strike confirm Pleistocene-Holocene slip. Galadini et al., } \\
\text { 1997a,b; Giraudi, 1988a. Throw-rate extrapolated from trench } \\
\text { sites. }\end{array}$ & 0.35 & 8.0 & 6.0 \\
\hline & $002 \mathrm{Fw}$ & Amplero & 384594 & 4639570 & 283 & 42 & 13 & 1415 & $\begin{array}{l}15 \mathrm{~m} \text { high bedrock scarp? The scarp is very degraded and also } \\
\text { may have been partially buried by Quaternary sediments from the } \\
\text { large river system that flowed axially along the Trassaco valley } \\
\text { during the demise of the last glaciation. Two scarps, } 3 \text { and } 4.5 \mathrm{~m} \\
\text { high, respectively, offset an alluvial fan at UTM } 0385440 ; \\
4638129 \text {. The fan is graded to the river sediment surface } \\
\text { implying it may be significantly younger than } 18 \text { ka. }\end{array}$ & 0.83 & 15.5 & 1.5 \\
\hline & $003 \mathrm{Fw}$ & Amplero & 384718 & 4638512 & 233 & 55 & 20 & 1415 & As for 002 . & 0.83 & 15.5 & 1.5 \\
\hline & $004 \mathrm{Hw}$ & C. le Pardo & 390122 & 4631873 & 280 & 50 & 11 & 350 & $\begin{array}{l}\text { Scarp, with a possible } 7 \mathrm{~m} \text { offset of Pleistocene conglomerate. } \\
\text { Trenches and geomorphology along strike confirm Pleistocene- } \\
\text { Holocene slip. Galadini et al., 1997a,b; Giraudi, 1988a. }\end{array}$ & 0.38 ? & 25.0 & 11.0 \\
\hline & 005 Main & M. Meria & 381168 & 4642841 & 228 & 70 & 5 & 730 & $\begin{array}{l}\text { Scarp. 8-m-high exposing bedrock. Trenches and geomorphology } \\
\text { along strike confirm Pleistocene-Holocene slip. Galadini et al, } \\
\text { 1997a,b; Giraudi, 1988a. }\end{array}$ & 0.44 & 10.2 & 4.0 \\
\hline \multirow[t]{4}{*}{ Sulmona } & $006 \mathrm{Fw}$ & Pacentro & 418410 & 4656207 & 258 & 38 & 15 & 1000 & $\begin{array}{l}\text { No scarp found, probably due to road construction. Maximum } \\
\text { assumed rate. Studies along strike confirm activity. Bosi, 1975; } \\
\text { Bosi and Messina, 1991; Miccadei et al., } 1992 \text {. }\end{array}$ & 0.30 & 4.0 & 12.2 \\
\hline & 007 All & Popoli & 403279 & 4670291 & 141 & 48 & 7 & 500 & $\begin{array}{l}\text { No scarp found, probably due to road construction. Maximum } \\
\text { assumed rate. Vittori et al. } 1 \text { (1995) describe offet Quaternary lake } \\
\text { beds and fans close by so activity confirmed. Geomorphic studies } \\
\text { of oversteepened slopes along scarps confirm activity. Bosi, } \\
\text { 1975; Bosi and Messina, 1991; Miccadei et al., 1992. }\end{array}$ & 0.30 & 25.0 & 8.5 \\
\hline & 008 All & Roccacasale & 407610 & 4664659 & 209 & 52 & 10 & 2000 & $\begin{array}{l}\text { Two parallel bedrock scarps, with summed height of ca. } 20 \mathrm{~m} \text {. } \\
\text { Lower scarp offsets the slope vertically by ca. } 10 \mathrm{~m} \text {. See } \\
\text { Miccadei et al,, 1992; Sylos Labini et al., 1993; Vittori et al., } \\
\text { 1995. Scarp higher on the hillside not visited and we may have } \\
\text { underestimated its height (for example see Vittori et al., 1995). } \\
\text { Offset Pleistocene fans with surficial scarps confirm recent } \\
\text { activity (Vittori et al., 1995). }\end{array}$ & $1.10 ?$ & 18.0 & 1.5 \\
\hline & 009 Main & Badia & 411154 & 4661141 & 188 & 65 & 7 & 1800 & $\begin{array}{l}\text { Bedrock scarps total ca. } 18 \text { m. See Miccadei et al., 1992; Sylos } \\
\text { Labini et al., 1993; Vittori et al., } 1995 .\end{array}$ & 1.00 & 13.0 & 3.6 \\
\hline \multirow[t]{5}{*}{ Scurcola } & $010 \mathrm{Fw}$ & $\begin{array}{l}\text { Scurcola } \\
\text { Marsicana }\end{array}$ & 362173 & 4658970 & 232 & 68 & 12 & 1000 & $\begin{array}{l}\text { No scarp found, probably due to burial by large drainage system. } \\
\text { Rate extrapolated from nearby scarp and assumed maximum rate. }\end{array}$ & 0.50 & 11.7 & 7.0 \\
\hline & 011 All & La Portella & 346579 & 4672869 & 176 & 52 & 6 & 300 & $\begin{array}{l}\text { Bedrock scarp with ca. } 5-6 \mathrm{~m} \text { throw. Drainage offset and } \\
\text { wingap present at La Portella. Drainage now flows into karst } \\
\text { caves. }\end{array}$ & 0.30 & 32.0 & 14.0 \\
\hline & $012 \mathrm{Fw}$ & St. Stefano & 353281 & 4665769 & 251 & 49 & 8 & 1455 & $\begin{array}{l}\text { Bedrock scarp altered by road construction to the west of the } \\
\text { village. Degraded. Upto } 15 \mathrm{~m} \text { high. }\end{array}$ & 0.83 & 22.0 & 4.3 \\
\hline & $013 \mathrm{Fw}$ & Cese & 368480 & 4650441 & 270 & 53 & 15 & 268 & $\begin{array}{l}\text { No scarp found, probably due to burial by large Holocene } \\
\text { drainage system. The throw-rate is probably no greater than the } \\
\text { value stated. }\end{array}$ & 0.30 & 2.0 & 16.0 \\
\hline & 013B Fw & Cese & 365000 & 4656530 & 261 & 42 & 38 & 350 & $\begin{array}{l}\text { No scarp found, probably due to burial by large Holocene } \\
\text { drainage system. The throw-rate is probably no greater than the } \\
\text { value stated. }\end{array}$ & 0.40 & 7.0 & 10.7 \\
\hline \multirow[t]{2}{*}{ Liri } & 014 All & Beatrice Cenci & 356964 & 4654004 & 150 & 53 & 6 & 100 & $\begin{array}{l}\text { Bedrock scarp juxtaposing carbonates with Flysch on roadside. } \\
6 \mathrm{~m} \text {. Offset of slope clear, but no Quaternary sediments. }\end{array}$ & 0.33 & $48.0 ?$ & 21.0 \\
\hline & 015 All & Pagliara & 361395 & 4651777 & 155 & 50 & 13 & 400 & $\begin{array}{l}\text { Bedrock scarp. } 10 \mathrm{~m} \text {. Offset of slope but no Quaternary } \\
\text { sediments. }\end{array}$ & 0.55 & 43.5 & 15.5 \\
\hline
\end{tabular}


Table 1 (continued)

\begin{tabular}{|c|c|c|c|c|c|c|c|c|c|c|c|c|}
\hline Fault name & $\begin{array}{l}\text { Locality } \\
\text { number }\end{array}$ & $\begin{array}{l}\text { Nearest town or } \\
\text { geomorphic } \\
\text { feature of note }\end{array}$ & $\begin{array}{l}\mathrm{X} \text { UTM } \\
\text { value }\end{array}$ & $\begin{array}{l}\text { Y UTM } \\
\text { value }\end{array}$ & $\begin{array}{l}\text { Slip direction } \\
\text { mean in degrees }\end{array}$ & $\begin{array}{l}\text { Plunge of } \\
\text { slip vector }\end{array}$ & $\begin{array}{l}\text { Slip vector } 99 \% \\
\text { confidence cone }\end{array}$ & $\begin{array}{l}\text { Total throw of } \\
\text { pre-rift strata } \\
\text { (metres) } \pm<\text { ca. } \\
200 \mathrm{~m}\end{array}$ & $\begin{array}{l}\text { Notes on offset geomorphic features and palaeoseismological } \\
\text { sites used to constrain throw rates }\end{array}$ & $\begin{array}{l}\text { Throw rate } \\
(\mathrm{mm} / \mathrm{yr}) \\
\pm<0.2 \mathrm{~mm} / \mathrm{yr}\end{array}$ & $\begin{array}{l}\text { Distance along } \\
\text { fault }(\mathrm{km})\end{array}$ & $\begin{array}{l}\text { Distance from } \\
\text { fuult center } \\
(\mathrm{km})\end{array}$ \\
\hline & 016 Main & Capistrello & 365852 & 4647538 & 212 & 71 & 5 & 1500 & $\begin{array}{l}\text { Bedrock scarp } 20 \mathrm{~m} \text {. Offset of slope but no Quaternary sediments. } \\
\text { Windgap with offset Pleistocene drainage. Offset of ca. } 20 \mathrm{~m} \text { (see } \\
\text { Giraudi and Frezzotti (1986) for data on drainage evolution and } \\
\text { interfluve elevations). }\end{array}$ & 1.10 & 37.0 & 9.6 \\
\hline & $017 \mathrm{Fw}$ & Case Cascone & 385349 & 4626065 & 296 & 74 & 8 & 700 & $\begin{array}{l}\text { Bedrock scarp. 5-7 m. Offset of slope but no Quaternary } \\
\text { sediments. }\end{array}$ & 0.38 & 8.0 & 19.5 \\
\hline & 17B & Case Cascone & 393000 & 4620000 & 237 & 70 & $\begin{array}{l}\text { Mean of only two } \\
\text { values }\end{array}$ & 100 & See 017 . & 0.10 & 0.0 & 27.5 \\
\hline & $018 \mathrm{Fw}$ & $\begin{array}{l}\text { S. Giovanni } \\
\text { Superiore }\end{array}$ & 379508 & 4633299 & 226 & 58 & 6 & 2000 & $\begin{array}{l}\text { Rate for } 020 \text { used. Possible offset of Pleistocene fan. } 20 \mathrm{~m} \text {. Scarp } \\
\text { is degraded. }\end{array}$ & 1.11 & 17.5 & 10.3 \\
\hline & 019 All & Morrea & 376509 & 4634762 & 221 & 38 & 11 & 2000 & $\begin{array}{l}\text { Rate for } 020 \text { used. Some degraded fault scarps present offsetting a } \\
\text { bench in a Pleistocene fan. }\end{array}$ & 1.11 & 21.5 & 7.3 \\
\hline & $020 \mathrm{Fw}$ & Civita d' Antino & 374387 & 4638749 & 215 & 74 & 8 & 2000 & $\begin{array}{l}\text { Bedrock scarp hidden in forest (UTM } 0373946,4638900 \text { ) offsets } \\
\text { spurs and slopes. } 16-20 \mathrm{~m} \text {. Offset of slope but no Quaternary } \\
\text { sediments. }\end{array}$ & 1.11 & 18.6 & 2.8 \\
\hline \multirow[t]{3}{*}{ L'Aquila } & 021 All & Caporciano & 391951 & 4679798 & 256 & 42 & 8 & 300 & $\begin{array}{l}\text { Bedrock scarp visible NE of main road. } 5 \mathrm{~m} \text {. Offset of slope but } \\
\text { no Quaternary sediments on scarp. }\end{array}$ & 0.27 & 3.0 & 18.6 \\
\hline & 022 Main & Barisciano & 383561 & 4689552 & 237 & 56 & 3 & 2500 & $\begin{array}{l}2-3 \text { antithetic bedrock scarps ponding Holocene drainage. } \\
\text { Drainage used to flow into hanging wall of the main fautl and is } \\
\text { now separated from the basin by windgaps. } 15 \mathrm{~m} \text { total offset. } \\
\text { Also bedrock scarp downthrowing SW, } 10 \mathrm{~m} \text {. Total post-glacial } \\
\text { throw is ca. } 25 \mathrm{~m} \text { (see Bagnaia et all. (1989) and Bertini and Bosi } \\
\text { (1993) for basin history). }\end{array}$ & 1.38 & 16.5 & 5.8 \\
\hline & 023 Main & M. S. Franco & 368500 & 4698400 & 198 & 38 & 6 & 1200 & $\begin{array}{l}\text { Large striated fault surface present possibly due to landslip. } \\
\text { Inconclusive scarp observations. Also, scarp at 03692924, } \\
4701335 \text {, near Mte. S. Franco on roadside. Maximum assumed } \\
\text { rate. }\end{array}$ & 0.20 & 36.0 & 15.3 \\
\hline \multirow[t]{3}{*}{ Barete } & $033 \mathrm{Fw}$ & Near L'Aquila & 362067 & 4699769 & 204 & 61 & 10 & 1400 & $\begin{array}{l}\text { Inconclusive scarp observations due to scarp degradation. The } \\
\text { bedrock scarp that is present appears smaller than at 034. Possible } \\
\text { active fault ca. } 20 \mathrm{~km} \mathrm{NE} \text { (near Campotosto) with } 0.2-0.4 \text { slip- } \\
\text { rate (Bachetti et al., 1990). }\end{array}$ & 0.4 & 8.0 & 3.0 \\
\hline & $034 \mathrm{Fw}$ & Barete & 360149 & 4700476 & 229 & 51 & 12 & 1700 & $\begin{array}{l}\text { Bedrock Scarp. } 7-10 \mathrm{~m} \text { (UTM } 0358438,4702072) \text {. Slope offset } \\
\text { but no Quaternary deposits noted. Blumetti (1995) and Blumetti } \\
\text { et al. (1993) mention offset Holocene deposits and possible slip } \\
\text { during the } 1703 \text { earthquake. }\end{array}$ & 0.55 & 11.0 & 0.0 \\
\hline & $035 \mathrm{Fw}$ & Marana & 354574 & 4706216 & 130 & 65 & 13 & 400 & $\begin{array}{l}\text { No scarp found due to town built on the fault. The throw-rate is } \\
\text { probably no greater than the value stated. }\end{array}$ & 0.30 & 2.5 & 9.0 \\
\hline \multirow[t]{3}{*}{$\begin{array}{ll}\text { Sella } & \text { di } \\
\text { Corno }\end{array}$} & $046 \mathrm{Fw}$ & Micigliano & 340759 & 4701283 & 170 & 55 & 6 & 300 & $\begin{array}{l}\text { No scarp found. The throw-rate can be no greater than the value } \\
\text { stated. }\end{array}$ & 0.10 & 24.5 & 12.5 \\
\hline & 047 All & Sella di Corno & 347049 & 4695166 & 223 & 57 & 8 & 1000 & $\begin{array}{l}\text { Degraded scarp due to road construction. Scarp could be upto } 6 \mathrm{~m} \\
\text { on side of road. }\end{array}$ & 0.33 & 12.0 & 0.0 \\
\hline & $048 \mathrm{Fw}$ & La Forca & 354950 & 4685754 & 310 & 45 & 20 & 100 & $\begin{array}{l}\text { Bedrock scarp. } 1 \mathrm{~m} \text { maximum. Offset of slope but no Quaternary } \\
\text { sediments. }\end{array}$ & 0.05 & 3.0 & 9.0 \\
\hline \multirow[t]{5}{*}{$\begin{array}{l}\text { Pescass- } \\
\text { eroli }\end{array}$} & $049 \mathrm{Fw}$ & $\begin{array}{l}\text { Civitella } \\
\text { Alfadena }\end{array}$ & 411513 & 4624397 & 262 & 32 & 12 & 100 & Bedrock Scarp. $3 \mathrm{~m}$. Offset of slope but no Quaternary sediments. & 0.16 & 1.5 & 8.5 \\
\hline & $050 \mathrm{Fw}$ & Villetta Barrea & 408903 & 4626329 & 249 & 27 & 13 & 800 & $\begin{array}{l}\text { Degraded bedrock Scarp. } 5 \mathrm{~m} \text {. Offset of slope but no Quaternary } \\
\text { sediments. Earthquake (Ms } 5.9 \text { ) in 1984. (Westaway et al., 1989). }\end{array}$ & 0.27 & 5.0 & 5.0 \\
\hline & $051 \mathrm{Fw}$ & M. Forcone & 407351 & 4626281 & 241 & 9 & 40 & 1000 & $\begin{array}{l}\text { Bedrock scarp. } 10 \mathrm{~m} \text {. Offset of slope but no Quaternary } \\
\text { sediments. }\end{array}$ & 0.55 & 6.5 & 3.5 \\
\hline & $052 \mathrm{Fw}$ & Opi & 403875 & 4627983 & 226 & 64 & 10 & 1700 & $\begin{array}{l}\text { Bedrock scarp. } 10 \mathrm{~m} \text {. Offset Quaternary sediments across } \\
\text { bedrock scarp. Also, offset Quaternary on a fault in the hanging } \\
\text { wall to the main fault (Galadini and Messina, 1993a,b; Galadini } \\
\text { et al., } 19999) \text {. The value in the next column sums values for these } \\
\text { two faults. }\end{array}$ & 0.83 & 10.0 & 4.0 \\
\hline & $053 \mathrm{Fw}$ & La Canala & 401500 & 4631200 & 188 & 51 & 14 & 1000 & $\begin{array}{l}\text { Bedrock scarp. } 10 \mathrm{~m} \text {. Offset Quaternary sediments (see Galadini } \\
\text { and Messina, 1993a,b). }\end{array}$ & 0.55 & 14.0 & 4.0 \\
\hline
\end{tabular}


Table 1 (continued) $\begin{array}{lll}\text { (metres) }) \pm<\mathrm{ca} \text {. } & & \\ & & \end{array}$ $200 \mathrm{~m}$

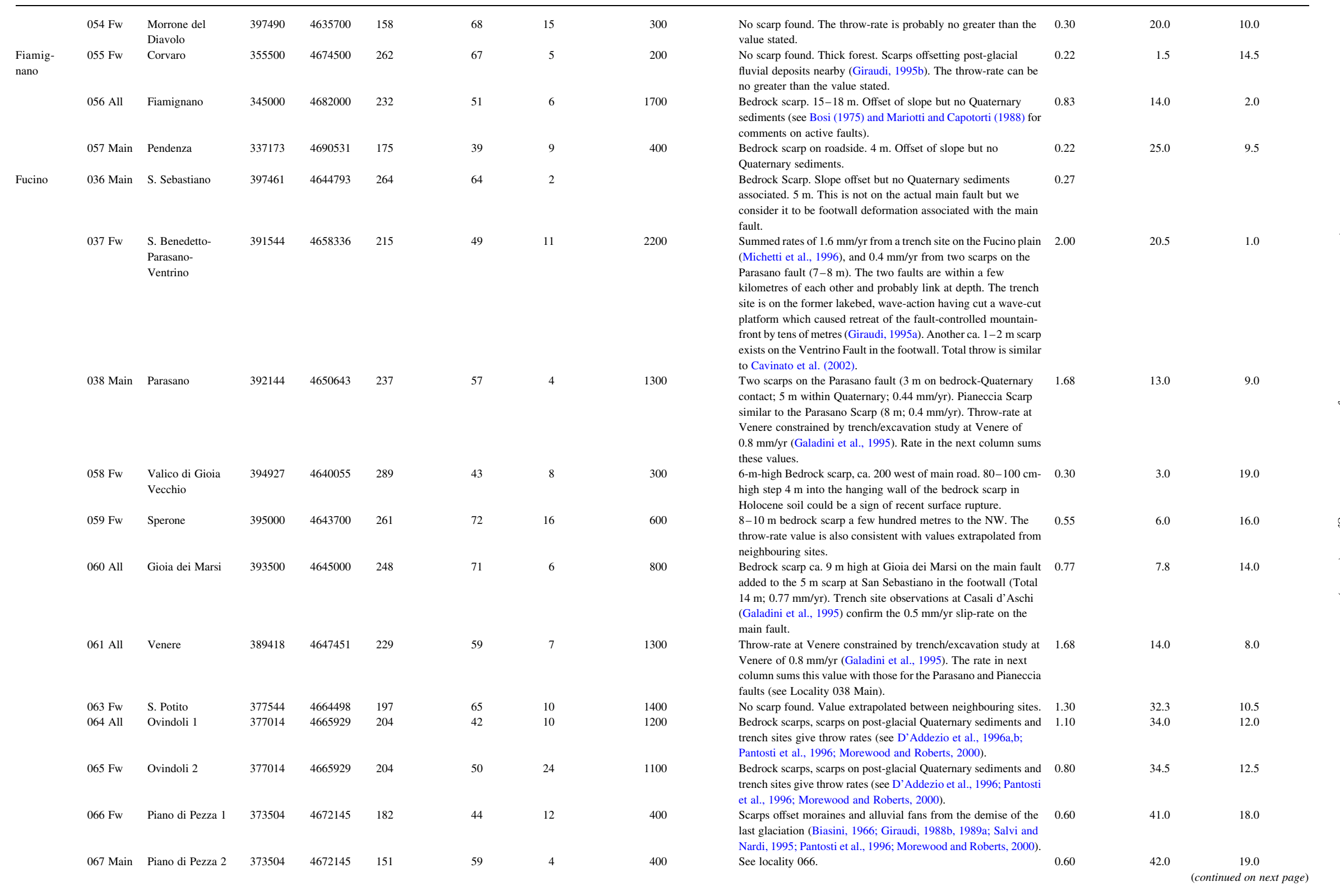


Table 1 (continued)

\begin{tabular}{|c|c|c|c|c|c|c|c|c|c|c|c|c|}
\hline 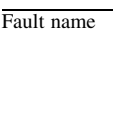 & $\begin{array}{l}\text { Locality } \\
\text { number }\end{array}$ & $\begin{array}{l}\text { Nearest town or } \\
\text { geomorphic } \\
\text { feature of note }\end{array}$ & $\begin{array}{l}\mathrm{X} \text { UTM } \\
\text { value }\end{array}$ & $\begin{array}{l}\text { Y UTM } \\
\text { value }\end{array}$ & $\begin{array}{l}\text { Slip direction } \\
\text { mean in degrees }\end{array}$ & $\begin{array}{l}\text { Plunge of } \\
\text { slip vector }\end{array}$ & $\begin{array}{l}\text { Slip vector 99\% } \\
\text { confidence cone }\end{array}$ & $\begin{array}{l}\text { Total throw of } \\
\text { pre-rift strata } \\
\text { (metres) } \pm<\text { ca. } \\
200 \mathrm{~m}\end{array}$ & $\begin{array}{l}\text { Notes on offset geomorphic features and palaeoseismological } \\
\text { sites used to constrain throw rates }\end{array}$ & $\begin{array}{l}\text { Throw rate } \\
(\mathrm{mm} / \mathrm{yr}) \\
\pm<0.2 \mathrm{~mm} / \mathrm{yr}\end{array}$ & $\begin{array}{l}\text { Distance along } \\
\text { fault }(\mathrm{km})\end{array}$ & $\begin{array}{l}\text { Distance from } \\
\text { fault center } \\
(\mathrm{km})\end{array}$ \\
\hline \multirow{8}{*}{ Rieti } & $068 \mathrm{Fw}$ & V. de Sevice & 364000 & 4667000 & 193 & 44 & 9 & & See observations of scarps in Morewood and Roberts (2000). & & & \\
\hline & $069 \mathrm{Fw}$ & Majelama & 370000 & 4664500 & 193 & 52 & 6 & & See observations of scarps in Morewood and Roberts (2000). & & & \\
\hline & 070 All & S. Iona & & & 183 & 59 & 8 & & See observations of scarps in Morewood and Roberts (2000). & & & \\
\hline & 072 Main & Quarry Tre Monti & & & 204 & 40 & 9 & & See observations of scarps in Morewood and Roberts (2000). & & & \\
\hline & 073 Main & $\begin{array}{l}\text { M. Cocuzzello } \\
\text { lats }\end{array}$ & 374140 & 4664191 & 194 & 41 & 12 & & See observations of scarps in Morewood and Roberts (2000). & & & \\
\hline & 074 All & Cittaducale & 332000 & 4695000 & 310 & 59 & 9 & 500 & $\begin{array}{l}\text { Trench investigations reveal late Quaternary offsets (see Michetti } \\
\text { et all, 1995). Although no scarps are clear and the trench site does } \\
\text { not provide a throw-rate, we use the same value as for site } 076 \text {, } \\
\text { which is an equivalent distance from the end of the fault. }\end{array}$ & 0.27 & 3.0 & 8.5 \\
\hline & $075 \mathrm{Fw}$ & Lisciano & 328705 & 4701991 & 266 & 82 & 6 & 1000 & $\begin{array}{l}\text { which is an equivalent distance from the end of the fault. } \\
\text { No scarp found due to road construction but unlikely to be }>7 \mathrm{~m} \\
\text { high (see Cello et al., 1995, 1997; Michetti et al., 1995; Tondi } \\
\text { et al., 1997). }\end{array}$ & 0.40 & 10.5 & 1.0 \\
\hline & $076 \mathrm{Fw}$ & Reatino & 323500 & 4711000 & 205 & 46 & 6 & 500 & $\begin{array}{l}\text { Bedrock Scarp } 5 \mathrm{~m} \text { high. Trench observations on a fault in the } \\
\text { hanging wall also reveal Holocene slip at } 0.4 \mathrm{~mm} / \mathrm{yr} \text { (Michetti } \\
\text { et al., 1995). The figure in the next column is that for scarp height } \\
\text { on the main fault plane. }\end{array}$ & 0.27 & 21.0 & 9.5 \\
\hline \multirow[t]{5}{*}{$\begin{array}{l}\text { Cassino } \\
\text { South }\end{array}$} & $163 \mathrm{Fw}$ & S. Pietro Infine & 416659 & 4589252 & 277 & 52 & 7 & 700 & $\begin{array}{l}\text { No scarp found. Maximum rate assumed on well-exposed } \\
\text { Pleistocene breccia covered slope. }\end{array}$ & 0.10 & 4.0 & 12.5 \\
\hline & 164 Main & $\begin{array}{l}\text { S.Vittore del } \\
\text { Lazio }\end{array}$ & 412218 & 4590832 & 248 & 41 & 6 & 1100 & $\begin{array}{l}\text { Bedrock scarp. } 4 \mathrm{~m} \text {. Offset of slope but no Quaternary sediments } \\
\text { observed. Offset Pleistocene sediments reported in the literature } \\
\text { (Bosi, 1975; Raffy, 1982, 1983; Bosi and Mercier, 1993). }\end{array}$ & 0.22 & 9.0 & 8.0 \\
\hline & 165 All & Cervaro & 409548 & 4593686 & 225 & 53 & 10 & 1100 & $\begin{array}{l}\text { Degraded Scarps. } 6 \mathrm{~m} \text { maximum. No offset Quaternary sediments } \\
\text { observed. Clear range front morphology with truncated spurs (see } \\
\text { Bosi. 1975; Raffy, 1982: Bosi and Mercier. 1993). }\end{array}$ & 0.33 & 13.0 & 0.6 \\
\hline & $166 \mathrm{Fw}$ & Elia Portella & 406085 & 4598019 & 181 & 45 & 7 & 1200 & $\begin{array}{l}\text { No scarp found due to road construction but unlikely to be }>5 \mathrm{~m} \\
\text { high. }\end{array}$ & 0.27 & 18.5 & 6.0 \\
\hline & $167 \mathrm{Fw}$ & Cancello & 400599 & 4605376 & 152 & 59 & 11 & 100 & $\begin{array}{l}\text { No scarp found due to road construction but likely to be }<2 \mathrm{~m} \\
\text { high due to sub-horizontal slip-vector. }\end{array}$ & 0.10 & 29.0 & 16.0 \\
\hline Leonessa & 172 & Leonessa & 332371 & 4714421 & 053 & 58 & 4 & 1000 & $\begin{array}{l}\text { Controls a Pleistocene-Holocene basin. Offset Pleistocene } \\
\text { fluvial terraces. (see Michetti and Serva, 1991; Cello et al., 1997; } \\
\text { Tondi, 2000). Clear 5-8-m-high bedrock scarp and striated main } \\
\text { fault plane. Offsets slope but no Quaternary. } 50-80 \mathrm{~cm} \text { high } \\
\text { angular step in soil in ?Holocene hanging wall of main fault plane } \\
\text { and lichen stripes on main fault plane may indicate recent surface } \\
\text { rupture. }\end{array}$ & $0.3-0.4$ & & \\
\hline \multirow[t]{2}{*}{$\begin{array}{l}\text { Campo } \\
\text { Imperatore }\end{array}$} & 180 & Val Maone & 0380389 & 4701869 & & & & 600 & 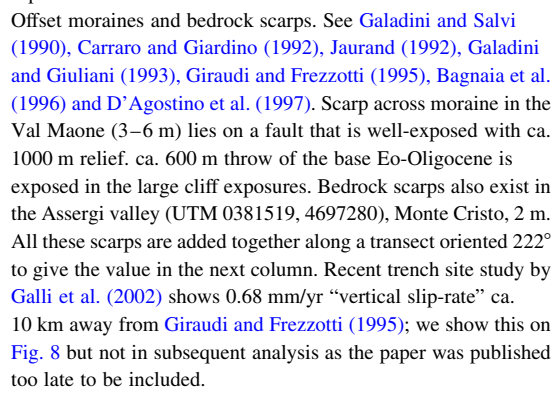 & $0.7-1.1$ & & \\
\hline & 181 & $\begin{array}{l}\text { Campo } \\
\text { Imperatore }\end{array}$ & 0386505 & 4700028 & & & & & $\begin{array}{l}\text { Bedrock scarp offsets slope (throw } 6 \mathrm{~m} \text { ) with possible offsets of } \\
\text { Quaternary within a few hundred metres. }\end{array}$ & 0.33 & & \\
\hline Maiella & 190 & $\begin{array}{l}\text { Passo di } \\
\text { Leonardo }\end{array}$ & 0422270 & 4660086 & & & & 2100 & $\begin{array}{l}\text { Degraded 10-15-m-high bedrock scarp. The scarp is less } \\
\text { convincing than others we have measured and the deduced throw } \\
\text { rate needs further study. Offsets Pleistocene sediments on } \\
\text { published maps (Vezzani and Ghisetti, 1998). Possible } \\
\text { earthquake in 1706; see Vittori et al. (1995). }\end{array}$ & $0.55-0.83 ?$ & & \\
\hline
\end{tabular}


Table 1 (continued)

\begin{tabular}{|c|c|c|c|c|c|c|c|c|c|c|c|c|}
\hline Fault name & $\begin{array}{l}\text { Locality } \\
\text { number }\end{array}$ & $\begin{array}{l}\text { Nearest town or } \\
\text { geomorphic } \\
\text { feature of note }\end{array}$ & $\begin{array}{l}\mathrm{X} \text { UTM } \\
\text { value }\end{array}$ & $\begin{array}{l}\text { Y UTM } \\
\text { value }\end{array}$ & $\begin{array}{l}\text { Slip direction } \\
\text { mean in degrees }\end{array}$ & $\begin{array}{l}\text { Plunge of } \\
\text { slip vector }\end{array}$ & $\begin{array}{l}\text { Slip vector } 99 \% \\
\text { confidence cone }\end{array}$ & $\begin{array}{l}\text { Total throw of } \\
\text { pre-rift strata } \\
\text { (metres) } \pm<\text { ca. } \\
200 \mathrm{~m}\end{array}$ & $\begin{array}{l}\text { Notes on offset geomorphic features and palaeoseismological } \\
\text { sites used to constrain throw rates }\end{array}$ & $\begin{array}{l}\text { Throw rate } \\
(\mathrm{mm} / \mathrm{yr}) \\
\pm<0.2 \mathrm{~mm} / \mathrm{yr}\end{array}$ & $\begin{array}{l}\text { Distance along } \\
\text { fault }(\mathrm{km})\end{array}$ & $\begin{array}{l}\text { Distance from } \\
\text { fault center } \\
(\mathrm{km})\end{array}$ \\
\hline \multirow[t]{4}{*}{ Carsoli } & 175 & $\begin{array}{l}\text { ca. } 200 \mathrm{WNW} \text { of } \\
\text { motorway bridge }\end{array}$ & 0344000 & 4666366 & 223 & 70 & & & $\begin{array}{l}\text { Bedrock fault scarp, } 6 \mathrm{~m} \text {, with main striated fault exposed. } \\
\text { Offsets slope but no Quaternary sediment. Slopes now cultivated } \\
\text { and altered by man but offset is clear. } 50 \mathrm{~cm} \text { high angular step in } \\
\text { soil, } 1 \mathrm{~m} \text { into the hanging wall may indicate recent surface } \\
\text { rupture. 2nd scarp perpendicular to the } 1.5 \text { with } 3 \mathrm{~m} \text { throw } \\
\text { accommodating along-strike stretching. }\end{array}$ & 0.33 & & \\
\hline & 176 & $\begin{array}{l}\text { Colli di } \\
\text { Montebove }\end{array}$ & 0346477 & 4662798 & 261 & 61 & & & $\begin{array}{l}\text { Bedrock scarp ca. } 7 \mathrm{~m} \text { high near cemetary and hairpin bend NE of } \\
\text { town (UTM } 0346737 ; 4663019 \text { ). }\end{array}$ & 0.38 & & \\
\hline & 177 & Road side & 0348565 & 4661918 & 295 & 61 & & & $\begin{array}{l}\text { 4-m-high bedrock scarp placing flysch against limestones on the } \\
\text { roadside. }\end{array}$ & 0.22 & & \\
\hline & 178 & Roadside & 0350223 & 4660627 & 323 & 38 & & & No scarp found but striated faults on limestones present. & & & \\
\hline \multirow[t]{2}{*}{ Norcia } & 173 & Castel S. Maria & 0345785 & 4730654 & & & & & $\begin{array}{l}\text { Bedrock scarp }(6 \mathrm{~m} \text { ) offsetting slope. Slope modified by man but } \\
\text { offset is clear (see Tondi, 2000). }\end{array}$ & 0.33 & & \\
\hline & 174 & & 0348790 & 4730464 & 233 & 58 & 8.4 & & $\begin{array}{l}\text { Bedrock scarp offsets slope but no Quaternary sediments obvious } \\
(3-4 \mathrm{~m}) \text {. }\end{array}$ & 0.33 & & \\
\hline $\begin{array}{l}\text { Cinque } \\
\text { Miglia, } \\
\text { Aremogna }\end{array}$ & & & & & & & & & $\begin{array}{l}\text { Offset Holocene alluvium and scarps in alluvium. Dated offset } \\
\text { Holocene deposits in trencheses. See Bosi (1975), Giraudi (1987), } \\
\text { Giraudi (1988sc, 1989b), Calderoni et al. (1991) and D'Addezio }\end{array}$ & $0.3-0.5$ & & \\
\hline
\end{tabular}



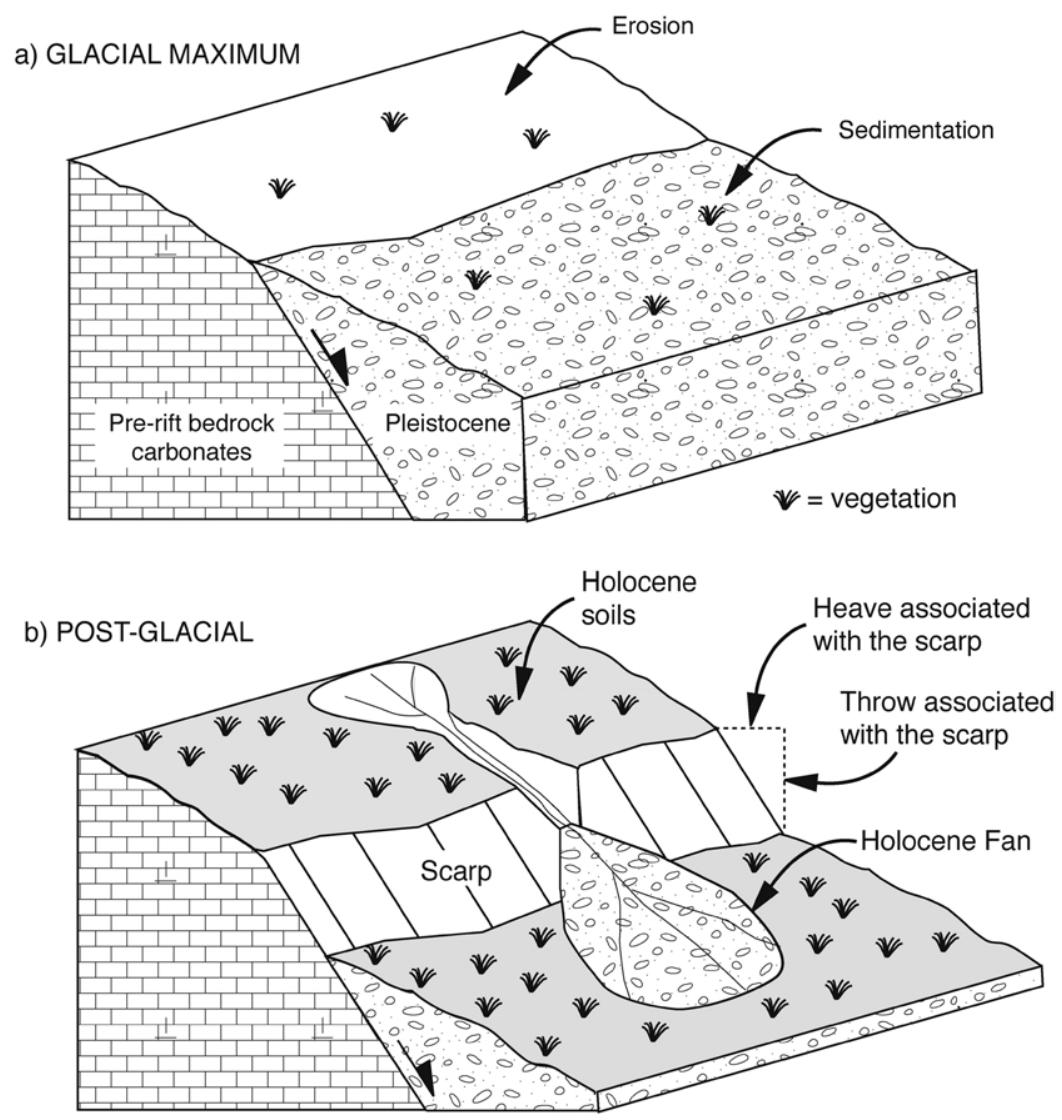

Fig. 7. Evolution of post-glacial fault scarps in the Lazio-Abruzzo Apennines. (a) Erosion and sedimentation rates are high relative to fault throw-rates so scarps are degraded or buried quickly and do not survive. Vegetation capable of stabilising slopes is sparse due to the cold climate. Smooth slopes exist across active faults. (b) Erosion and sedimentation rates decrease relative to fault throw-rates so scarps survive producing a cumulative offset of the smooth slopes that existed across active faults. Dense temperate vegetation stabilises the slopes and allows datable organic- and volcanic-rich post-glacial sediments to blanket the slopes. Holocene fans continue to degrade the scarps but these localities are easy to identify so throws across scarps can be measured elsewhere. If the top of the scarp is degraded then the throw is measured after projecting the eroded upper slope to its original extent (e.g. see Piccardi et al., 1999; Morewood and Roberts, 2000).

(ca. E-W) to the majority of our interpreted major faults (ca. NW-SE); (3) they exhibit scarps only a few metres high at their centres indicating very low throw-rates (Fig. 8b); (4) they decreased in activity after the late Pliocene evidenced by seismic reflection profiles (Cavinato et al., 2002). They have been interpreted as secondary structures accommodating late-Pleistocene to Holocene strain in the segment boundaries between the major faults (Morewood and Roberts, 2000). We also show the so-called 'Mte. D' Ocre fault' (Vezzani and Ghisetti, 1998) (Fig. 8), but are unconvinced that this is purely a tectonic fault. Others consider this to be an active tectonic fault due to ca. $20 \mathrm{~m}$ offset of an undated moraine (Giraudi, 1995b). If correct, the reported $1.1 \mathrm{~mm} / \mathrm{yr}$ slip-rate and ca. $5 \mathrm{~km}$ length produce a throw-rate-to-length profile much steeper than any of the other faults described herein. We believe this is anomalous and suggest that the offset of the moraine may be at least partly due to localised karstic collapse, a common feature in the high topography of the Apennines (e.g. Blumetti, 1995). The status of other relatively short faults, such as those measured at Localities 32, 36, 37 and the fault between localities 21 and 7 are unclear; these may also be secondary structures associated with segment boundaries or strain in the flexing regions between major normal faults; this needs further study, but we do not include them in our count of major faults.

We reject the hypothesis that bedrock scarps like those on the Trasacco, Liri, Carsoli and Fiamignano Faults do not imply activity since the last glaciation and are due to erosional exhumation (see Galadini, 1999). The scarps in question vary in height along strike (Fig. 8 and Table 1). Also, the scarp height variation occurs over a similar alongstrike distance to throw and slip-direction variations (see Fig. 8 and further analysis in Section 7). We find it inconceivable that such consistency between cumulative throw, scarp height and slip-directions is a coincidence and due to exhumation. We also note that the Fiamignano, Scurcola, Sella di Corno, Liri and Carsoli faults lie in the region where a GPS study documented extension but some authors claimed there were few major active normal faults (see Galadini, 1999; Galadini and Galli, 2000; D’Agostino et al., 2001a). However, other workers (Bosi, 1975; Michetti et al., 1995; Vittori et al., 1998; Michetti et al., 2000b and references therein) and our study shows that there are more 


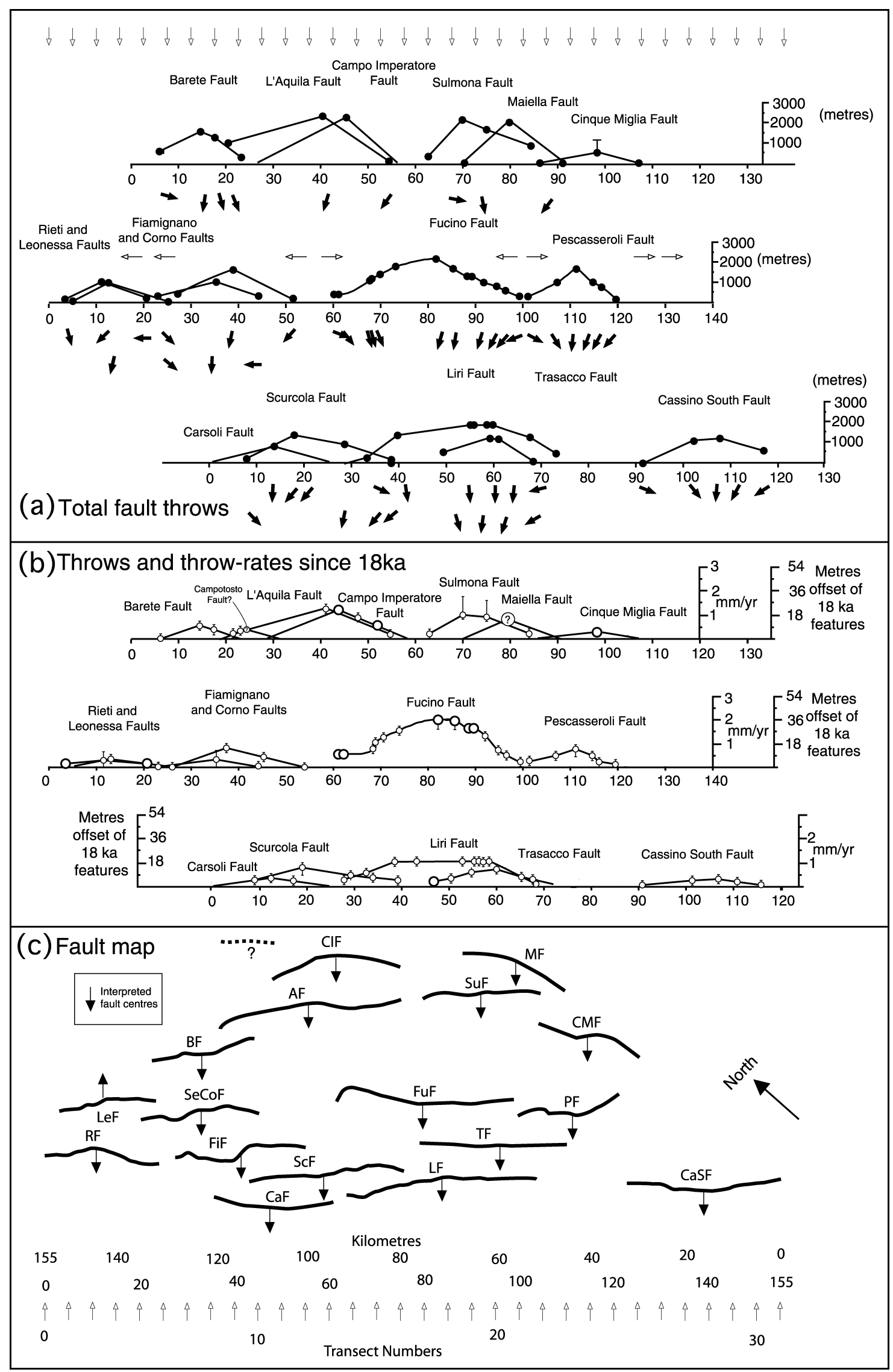




\section{(d) Rates calculated from offset $18 \mathrm{ka}$ glacial features and Holocene sediments: comparison of the Fucino fault with 3 certain faults and 1 possible fault near its lateral termination.}

- Measured fault throw. Errors usually c. $+/-200$ $\mathrm{m}$ (< size of symbol)

(?) Throw rate on the Maiella fault which is a maximum value and needs further study

$\rightarrow \quad$ Drainage directions rivers flowing axially along the faults

Measured scarp heights. Errors shown for scarp height measurement $(<0.2 \mathrm{~mm} / \mathrm{yr})$

Measured throw rates from published trench site or other palaeoseismic data (errors usually < size of symbol)

Measured throw rates on faults near the lateral termination of the Fucino fault

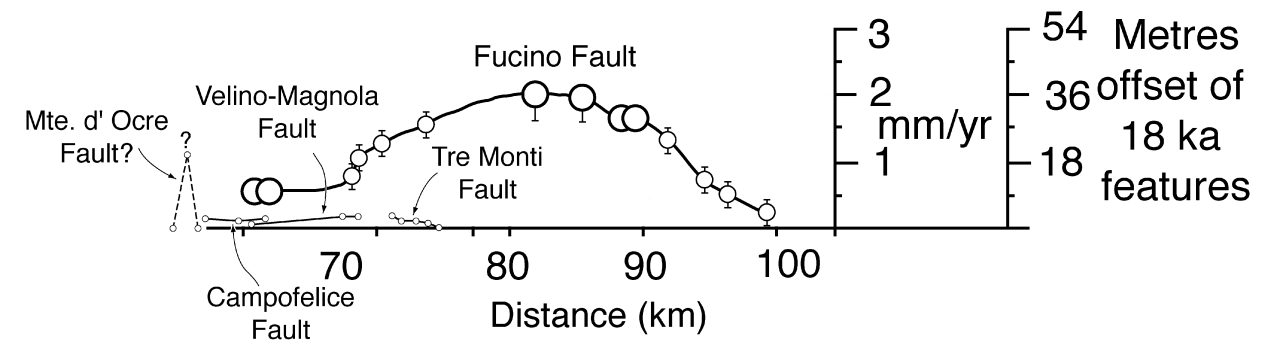

Fig. 8 (continued)

active faults within the region studied by D'Agostino et al. (2001a). Thus, we suggest the Fiamignano, Scurcola, Sella di Corno, Liri and Carsoli faults are active normal faults and are probably responsible for part of the extension measured with GPS.

Of the 21 faults we recognise, we conclude that four of them are either inactive or have throw-rates that are low relative to erosion/sedimentation rates, so no scarps are present. We term them inactive faults below, but readers should bear in mind that they may simply have low throwrates ( $<$ ca. $0.2 \mathrm{~mm} / \mathrm{yr}$ ). We consider the remaining 17 faults to be active because of the presence of post-glacial scarps (see Fig. 8).

\subsection{Regional kinematics}

For those active normal faults for which we have slipdirection data, we have calculated the mean fault-slip direction at the centres of the faults and combined these values to calculate the mean fault-slip direction for the active fault array (Fig. 9). We have not used data from more than $4 \mathrm{~km}$ away from the interpreted centres of the faults because they will be controlled by strains produced by along-strike stretching of hanging wall and footwall surfaces. The centres of the faults have been interpreted at positions that (1) lie close to the centre of the fault map trace, (2) lie close to the area of maximum throw and throwrate, and (3) lie close to the centre of symmetry of the converging patterns of fault slip. We consider the errors on the positions of the interpreted fault centres to be $<5 \%$ of the total fault length.

The mean fault-slip direction for the active fault array is $62^{\circ}$ plunge towards $222 \pm 4^{\circ}$ at the $99 \%$ confidence level $(N=189)$. This direction is at ca. $90^{\circ}$ to the fault strikes in the region (NW-SE) so the faulting is almost pure dip-slip. This conclusion contrasts with the studies of Galadini (1999) and Piccardi et al. (1999) who suggest regional oblique extension with a left-lateral shear sense. Both of these studies lack measurements from locations where we interpret the SE ends of faults (characterised by slip to the west). Thus, these studies do not report or explain converging patterns of fault-slip. Clearly, their kinematic data are incomplete, and we believe their oblique-slip interpretation is incorrect for this reason. We prefer our interpretation of NE-SW directed dip-slip with local leftand right-lateral oblique slip due to displacement gradient related strains. We note our interpretation is consistent with the ca. NE-SW regional $\sigma^{3}$ orientation from borehole break-out and earthquake solutions (Montone et al., 1999).

We have also calculated the same for the four inactive fault centres. The mean fault-slip direction for the inactive fault array is $216 \pm 4^{\circ}$ at the $99 \%$ confidence level

Fig. 8. Fault map together with throw and throw-rate profiles for active normal faults in the Lazio-Abruzzo Apennines. The profiles and the map are presented in their correct geographic locations along strike relative to each other using data from a hand-held GPS receiver. Black arrows show the map projections of slip-directions on the faults where a vertical, downward-pointing arrow indicates a slip-direction of $222^{\circ}$. Vertical white arrows show the positions of 31 transects across the area for which throw and throw-rate have been summed (see Fig. 10). Throw errors are $\pm 200 \mathrm{~m}$. Throw-rate errors shown are $\pm 0.2 \mathrm{~mm} / \mathrm{yr}$ although actual errors are almost certainly smaller than this. Abbreviated fault names as in Fig. 2. 
Inactive Fault Centres

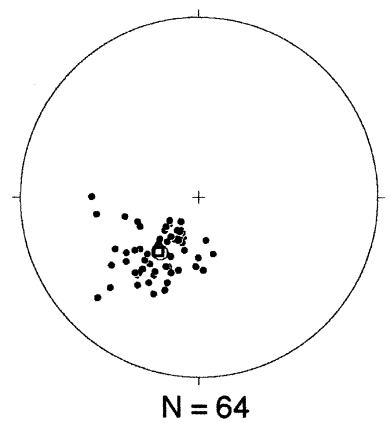

Active Fault Centres

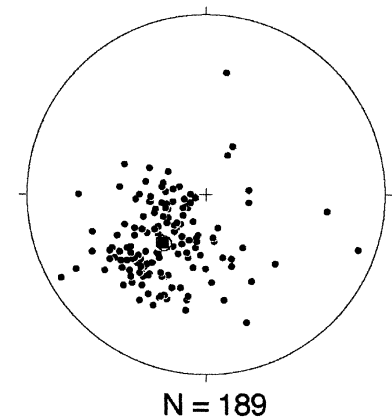

Means and $99 \%$ confidence cones for inactive (c) and active ( () fault centres

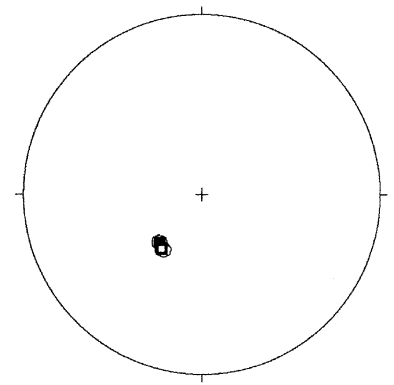

Fig. 9. Fault-slip direction data for the centres of normal faults in Lazio-Abruzzo. The data are a compilation of the relevant data from Fig. 6 (see text for details).

$(N=64)$. This direction also indicates almost pure dip-slip motion on NW-SE faults. The data do not allow the mean fault-slip directions for the active and inactive fault arrays to be distinguished at the $99 \%$ confidence level. If slip on the inactive faults pre-dates slip on the active faults, there is no need to suggest that the far-field stress orientations have changed during faulting. Rotations about vertical axes-if present-must occur slowly relative to fault-normal extension otherwise the mean fault-slip directions on the older faults would have been rotated away from the NE-SW direction. This is consistent with palaeomagnetic data for central Italy. Rotations about vertical axes have been measured for pre-Messinian sediments and have been related to differential thrust movements (Mattei et al., 1995). However, extensional basins have been shown not to have rotated about vertical axes since Messinian times (Mattei et al., 1996). The hypothesis of oblique extension, necessarily associated with rotation of fault blocks about vertical axes (Galadini, 1999; Piccardi et al., 1999), is inconsistent with palaeomagnetic data and our fault-slip data. Thus, although local oblique extension occurs near fault tips, as is common in other extensional areas (Roberts, 1996; Michetti et al., 2002a; Roberts and Ganas, 2000), the extension in the Lazio-Abruzzo Apennines is predominantly pure NE-SW dip-slip, at right angles to the NW-SE strike of the active normal fault system.

\subsection{Active fault spacing}

A notable feature of the Lazio-Abruzzo Apennines is the presence of parallel active faults that are in places spaced only $7-15 \mathrm{~km}$ apart. Transects running for only ca. $55 \mathrm{~km}$ NW-SE across strike intersect five or six active faults in the centre of the fault array. This contrasts with some other active normal fault systems where spacings can be as large as 70-80 km (central Greece, Jackson (1999); western Turkey, Armijo et al. (1996)) or even 150-200 km (Tibet, Armijo et al. (1996)), but similar values have been recorded in Nevada (De Polo and Anderson, 2000).

We also note that there are fewer active normal faults encountered along NW-SE transects across the NW and SE ends of the fault array, compared with the centre of the array. Below we investigate how this affects the cumulative heave and heave rate along the strike of the active faults defined above.

\subsection{Heave and heave-rate variations along the strike of the Lazio-Abruzzo Apennines}

We have summed throw and throw-rate values along 31 transects crossing all the active faults in the direction of $222^{\circ}$ to study how they and heave and heave-rate values vary along the strike of the region (Fig. 10). The transects were chosen every $5 \mathrm{~km}$ along the strike of the fault system. We do not include the Montereale and Laga Faults (Blumetti, 1995) because we have not measured their throw or throw-rates. Also, we have included the throw value for the Maiella fault $(2100 \mathrm{~m})$, but not its throw-rate value $(<0.83 \mathrm{~mm} / \mathrm{yr})$, because of our uncertainty concerning the latter (see Table 1). We show below that these uncertainties make little difference to our overall conclusions. We have calculated summed heave and heave-rate values from our summed throw and throw-rate values using trigonometry, assuming a planar fault geometry and a $45^{\circ}$ fault dip. The value for fault dip is poorly constrained because little information is available concerning the fault geometries at depth in Lazio-Abruzzo. We assume a value of $45^{\circ}$ for fault dips because this is likely to be close to the minimum value permissible for active normal faults dips (e.g. Jackson and White, 1989) and thus, produces a maximum value for cumulative heave and heave-rates. Actual cumulative heave and heave-rate values will be lower if steeper fault dips exist. Support for steeper faults may come from the mean value for all fault dips we have measured at the surface, which is $65^{\circ}(N=1653$; standard deviation $=14^{\circ}$ ) $($ Fig. 11). However, we do not know how fault dips measured at the surface compare with dips at depths as few seismic reflection profiles of sufficient quality exist in the published literature and no high quality focal mechanisms are available for large magnitude earthquakes 

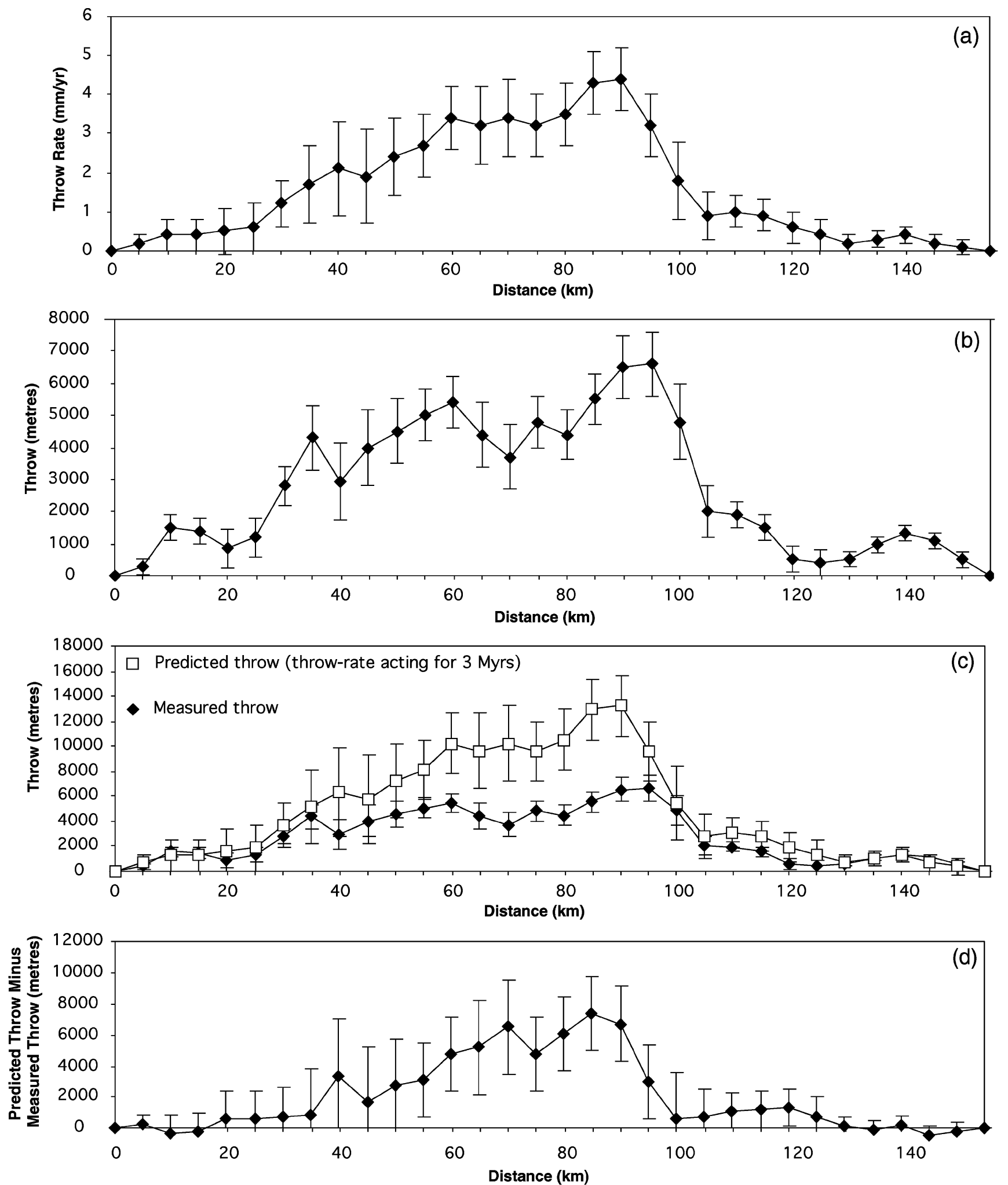

Fig. 10. Summed throw-rate (a) and throw (b) profiles for the active faults in Lazio-Abruzzo along the 31 transects indicated in Fig. 8 . Transects 1 and 2 of Fig. 2a would be located at about 160 and $0 \mathrm{~km}$, respectively. Throw errors are $\pm 200 \mathrm{~m}$ for each fault crossed on the transect. Throw-rate errors shown are $\pm 0.2 \mathrm{~mm} / \mathrm{yr}$ for each fault crossed on the transect although actual errors are almost certainly smaller than this. (c) Measured throws and throw predicted when measured throw-rates are allowed to run for 3 Myrs. Errors are as for (a) and (b). (d) Predicted throws minus the measured throws. Errors are as for (a) and (b). The centrally located maxima shows that throw-rate values have increased through time by the greatest amount relative to throw values in the centre of the fault array. Compare with Fig. 1. 


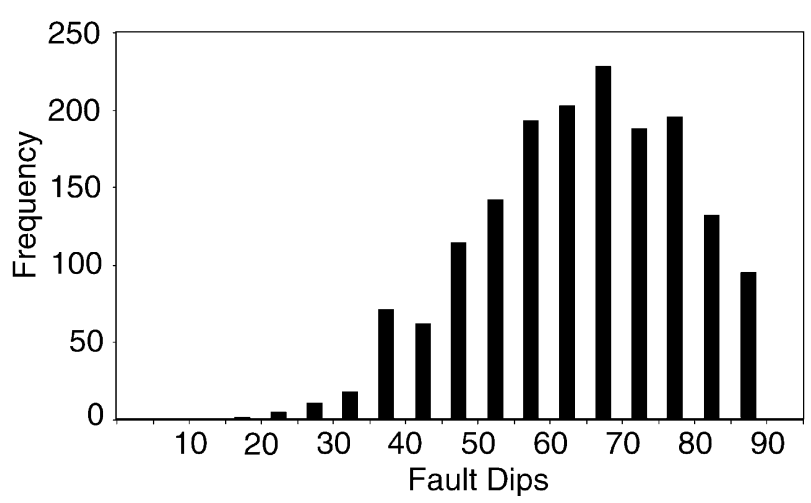

Fig. 11. Histogram of fault dips measured at the surface in Lazio-Abruzzo.

( $>$ Ms 6.0). However, we suspect that fault dips increase close to the surface. The nodal planes for the focal mechanisms for the 1984 Lazio-Abruzzo earthquakes (Ms 5.8 and Ms 5.2) dipped at $48-46^{\circ}$, similar to the value we use (Westaway et al., 1989). However, we present the raw throw and throw-rate data in Table 1 so actual heave and heave-rate values can be calculated in the future if more data become available concerning fault dips at depth.

The summed throw-rate and hence heave-rate values show a clear maxima close to the central area of the LazioAbruzzo Apennines $(4.4 \pm 0.8 \mathrm{~mm} / \mathrm{yr}$; calculated using $18 \mathrm{ka}$ ), decreasing in both directions along strike (Fig. 10). Values of $5.0 \pm 1.0$ and $5.7 \pm 1.1 \mathrm{~mm} / \mathrm{yr}$ are implied if we use 16 and $14 \mathrm{ka}$ for the time when the scarps started to form; we prefer the $18 \mathrm{ka}$ value. The values are similar to the value of $6 \pm 2 \mathrm{~mm} / \mathrm{yr}$ measured using GPS in the interval 1994-1999 (D'Agostino et al., 2001a), although we note the location and extent of the areas examined are different. Steeper fault dips could bring the heave-rate lower than $3 \mathrm{~mm} / \mathrm{yr}$, the upper bound to the maximum rate of extension implied by the triangulation study of Hunstad and England (1999). To the SE of the Cassino Fault, it is possible to cross the Apennines along a straight line transect oriented along $222^{\circ}$ without crossing an active fault known to us (for example along transect 1; Fig. 2a) (Corrado et al., $1997)$ so we consider the throw/heave-rate to be very low $(<0.2 \mathrm{~mm} / \mathrm{yr})$. A transect along $222^{\circ}$ located at the $\mathrm{NW}$ end of the fault system also shows very low throw/heave rates. Transect 2 (Fig. 2a) crosses (1) the northwestern end of the Rieti Fault, (2) possibly the end of the Leonessa fault, (3) the southeastern end of the active Norcia Fault, (4) the northwestern end of the Cittareale Fault, and (5) possibly the extreme end of the Mt. Vettore Fault. The Norcia and Cittareale faults show two scarps that total less than $9 \mathrm{~m}$ of post-glacial throw (located at UTM 0345785-4730654, and 0348790-4730464) indicating a maximum summed throw/ heave rate of only ca. $0.5 \mathrm{~mm} / \mathrm{yr}$. The throw-rate at the extreme tip of the Mt. Vettore Fault is not known but is probably negligible, as is that at the tips of the Rieti and Leonessa Faults. In summary, the $4.4 \pm 0.8 \mathrm{~mm} / \mathrm{yr}$ heave/ throw-rate maximum across the Lazio-Abruzzo Apennines decreases to close to zero $(<0.5-0.2 \mathrm{~mm} / \mathrm{yr})$ to the NW and
SE, suggesting the normal fault system dies out to the NW and SE. We are aware that there are other active faults further NW and SE (Fig. 2). However, we argue that these can be considered as separate fault systems in the sense used by Cowie and Roberts (2001) because the throw-rates die to zero before they are encountered. Note the decrease is even more marked if we include any slip on the Maiella, Montereale and Laga faults (located between the two transects), which as mentioned above, we do not include because of a lack of data or uncertainty in our measurements.

The summed throw and heave values show a similar spatial pattern, with a clear maxima $(6.6 \pm 0.8 \mathrm{~km})$ and values close to zero in both directions along strike (there is $<$ ca. 200 m vertical offset across the SE end of the Norcia Fault at the localities mentioned above) (Fig. 10).

These results support our earlier assertion (Section 1) that the active extension decreases both NW and SE of the Lazio-Abruzzo Apennines, and that we can define the two ends of the fault array to about $155 \mathrm{~km}$ apart.

Note that we have chosen not to calculate the displacement rate or cumulative displacement values in the slipdirections described above (Section 4.1). Thus, the actual heave and heave rate values will be lower where transects cross close to the ends of faults because of the oblique-slip in such locations. The rake values for oblique slip are $>$ ca. $45^{\circ}$ below horizontal so the throw values will only underestimate the displacement values near the ends of faults by ca. $<20 \%$. Thus, this does not change our conclusions. We have chosen to use this method because we know of no other study that has reported displacement values in measured slip directions because measurements of oblique slip at lateral fault terminations are rare (Roberts, 1996; Morewood and Roberts, 1999; Roberts and Ganas, 2000; Michetti et al., 2002a). We have chosen to show throws rather than displacement so our data can be compared with less complete datasets which do not include measurements of oblique slip at lateral fault terminations.

We have shown that slip-directions at the centres of the faults show almost pure dip-slip motion and rates of rotation about vertical axes are likely to be small relative to faultnormal heave rates. If this is correct then, for the centres of fault map traces, (1) the heave directions (same as mean fault slip direction $\left(222 \pm 4^{\circ}\right.$ at the $99 \%$ confidence level), (2) the heave, and (3) the heave-rates, represent the (i) finite and instantaneous extension directions, (ii) the amount of extension, and (iii) the extension rates for the last $18 \mathrm{kyrs}$.

If we have recognised all the major active faults, and no systematic decrease in fault dips occurs towards the SE across Lazio-Abruzzo, our data are inconsistent with the idea that extension rates are controlled by rotation of rigid plates about an Euler pole close to the Alps (Anderson and Jackson, 1987; Westaway et al., 1989). This hypothesis predicts extension rates increasing to the SE, the opposite of what we find for the SE end of the Lazio-Abruzzo Apennines. We doubt that we and others have missed any 
major active faults and find no reason to suspect a systematic decrease in fault dips towards the SE. Nonrigidity of the deforming continental material seems a more appropriate assumption given the gradients in strain we have measured.

\section{The relationships between fault throws, lengths and distance along the fault array}

In the following sections we examine whether the deformation patterns highlighted by Fig. 1 are recognisable in the Lazio-Abruzzo Apennines. The fault system is softlinked so we compare our observations with the predictions of Fig. 1b rather than Fig. 1c.

\subsection{Throw/length ratios}

The individual faults in Fig. 1b have throw/length ratios greater than that for the array as a whole; this resembles the pattern in the Lazio-Abruzzo Apennines. The 17 faults we have measured and consider to be active have lengths between about 20 and $40 \mathrm{~km}$ and maximum throws measured for pre-rift strata between ca. 500 and $2200 \mathrm{~m}$. The actual throw/length ratios are $0.035-0.083$, that is, towards the higher end of the comparable range of displacement/length ratios recorded from faults worldwide (0.001-0.1; Schlische et al., 1996) (Fig. 1). The summed throw profile in Fig. 10 is $155 \mathrm{~km}$ in length and shows a maximum summed throw of $6.6 \mathrm{~km}$. The throw/ length ratio for this summed profile is 0.042 . However, the summed profile is clearly not a single fault. The parallel sets of faults distributed by ca. $55 \mathrm{~km}$ across strike appear to be working together to accommodate the regional strain (Fig. 10). If throws are summed across strike for distances that are only ca. $5-10 \%$ of the array length-similar to the percentage distances commonly used in throw/length or $d /$ $L$ ratio studies (e.g. Schlische et al., 1996) - a throw/length ratio of 0.014 is implied (throw of $2.2 \mathrm{~km}$ associated with the Fucino fault, length $155 \mathrm{~km}$ ). This is less than the values for individual faults $(0.035-0.083)$.

\subsection{Spatial variation in throws, throw gradients and throw/length ratios}

The individual faults in Fig. 1b show throws that are greater for faults located progressively closer to the centre of the array; this pattern will become more pronounced during progressive deformation during the Stage 2 time period. For the Lazio-Abruzzo Apennines, we note that the faults with greatest throws are positioned in the centre of the region, decreasing towards the NW and SE. This is qualitatively visible in the throw profiles of Fig. 8. Quantitative analysis shows the above to be correct (Fig. 12a), so the studied faults resemble those in Fig. 1b in that those with the largest throws are located centrally within the array. The $R^{2}$ value of 0.603 suggests that there is a reasonably strong relationship between maximum fault throw and distance along the array. However, the throw/ length ratios show little or no correlation with distance along the array $\left(R^{2}=0.120\right)$ (Fig. 12b).

In Fig. 1b, faults show increasingly steep displacement gradients approaching the centre of the fault array (see also Fig. 1d). To investigate if this is true in the Lazio-Abruzzo Apennines, we have normalised the lengths of faults to emphasise the differences in throw between the faults. We have also plotted a number of graphs showing the relationships between fault throws, throw-rates and fault lengths (Fig. 13). We have found an inverse relationship between the normalised distance from the centre of an individual fault and fault throw (Fig. 13a). This is not a surprise, but we also note that different slopes (throw gradients) exist for this relationship for different faults (compare Fig. 13a with Fig. 1d). Quantitative analysis shows that slope values are correlated with distance along the overall array, increasing towards the centre of the array (Fig. 12c), but the $R^{2}$ value (0.558) shows that this is a relatively weak relationship. The same is true of the $y$ intercepts for this relationship, which increase towards the centre of the array (Fig. 12d). Again, the low $R^{2}$ value (0.487) shows that this is a relatively weak relationship. The above demonstrates a relatively weak, but perceptible increase in throw gradients for individual faults with proximity to the centre of the fault array similar to Fig. 1d.

We are interested in why the above $R^{2}$ values are low. If the hypothesis of Cowie and Roberts (2001) is correct, throw-profiles will adjust through time to a new throw-rate pattern in Stage 2 of the growth model where higher rates are found on more centrally-located faults. Thus, early in Stage 2, throw-rates will be high on central faults relative to distal faults, but throws values will not yet have had time to adjust to this pattern. This may mean that the fault system in the Lazio-Abruzzo Apennines is in an early stage of throwprofile readjustment following the initiation of fault interaction, but we have not proved it so far. To test this hypothesis we must investigate whether such a change in throw-rate has occurred (see Section 6.1), its timing, and the duration of faulting (see Section 6.2).

\section{Comparison of summed cumulative throws and throw-rates}

\subsection{Temporal variation in throw-rates}

Fig. 1b shows an early stage of faulting where the fault displacements accumulate at approximately the same rate for all faults followed by a post-interaction pattern where centrally located faults slip more rapidly than distal faults (see Fig. 1e). To investigate whether deformation rates have changed in this way in the Lazio-Abruzzo Apennines we have compared the summed throw and throw-rate profiles 
a)

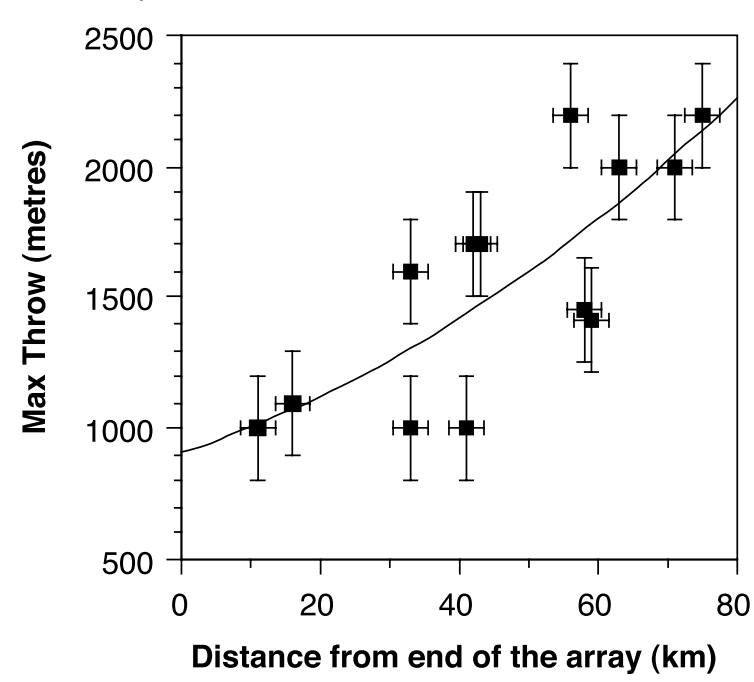

c) $\quad y=14.522 * 10^{\wedge}(7.0492 e-3 x) \quad R^{\wedge} 2=0.558$

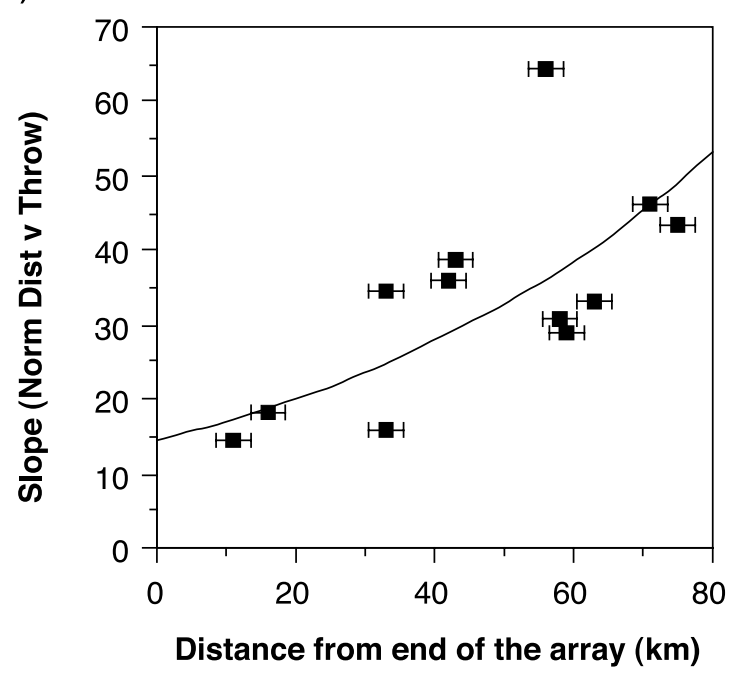

b)
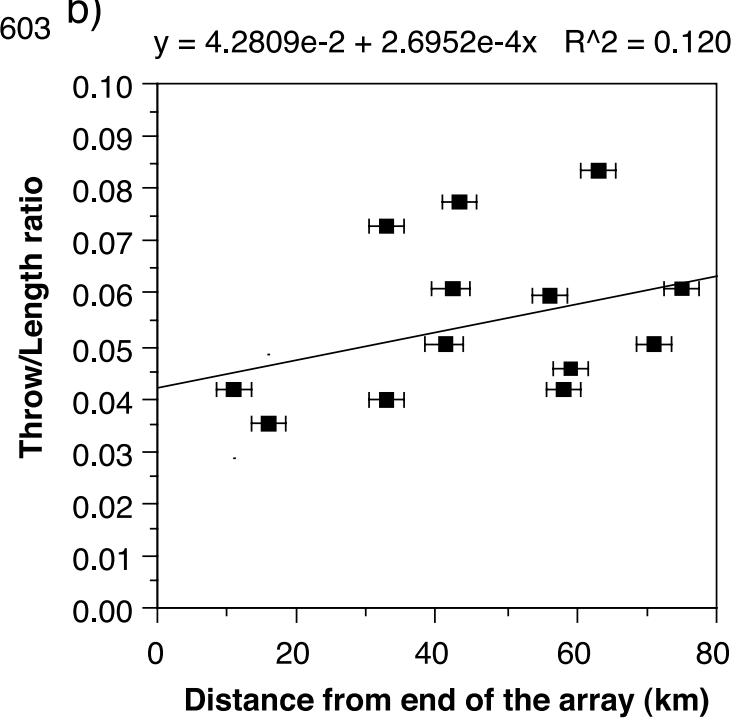

d) $\quad y=987.29 * 10^{\wedge}(5.3638 e-3 x) \quad R^{\wedge} 2=0.487$

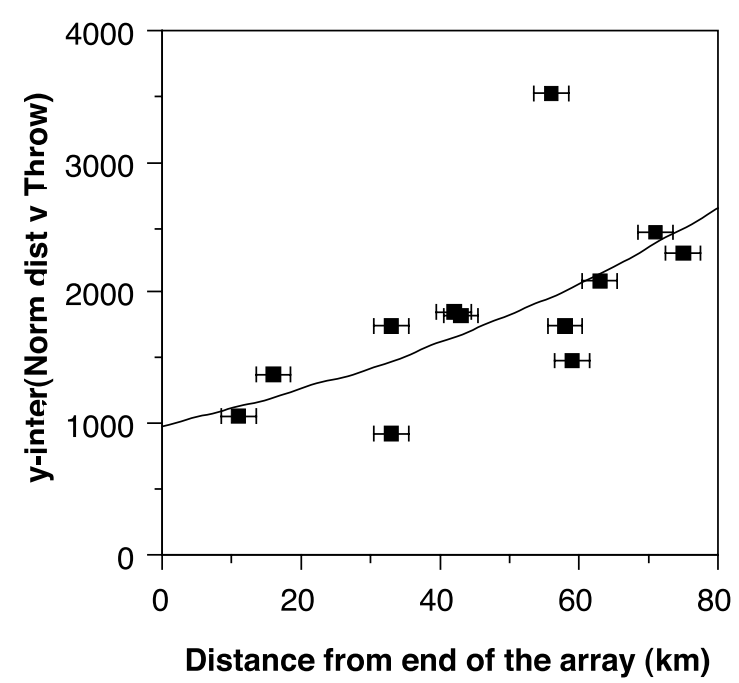

Fig. 12. Graphs showing how throw-related parameters vary along the strike of the Lazio-Abruzzo Apennines. Data from Table 2 and the regression equations in Fig. 13. Errors are $\pm 200 \mathrm{~m}$. The maximum throws, throw gradients and perhaps throw/length ratios on individual faults increase towards the centre of the fault array (compare with Fig. 15).

(Fig. 10). We have assumed three scenarios where the extension initiated at 2, 3 or $4 \mathrm{Ma}$, a range that probably encompasses the actual value given the uncertainty for its timing (e.g. Cavinato and De Celles, 1999; Roberts et al., 2002). As yet, we do not know which of these is correct but we will show that this does not affect our reasoning and we comment on the probable age in Section 6.2. We have calculated the throw profiles that would develop if the throw-rates we interpret for the last 18 kyrs were allowed to continue for 2, 3, or 4 Myrs (see Fig. 10 for the $3 \mathrm{Ma}$ calculations). If throw-rates have remained constant the calculated throw profile should be identical to the measured throw profile. However, we find that predicted throws are increasingly large compared with measured throws when approaching the centre of the fault array; this is even more apparent if we use throw-rates calculated over 16 or $14 \mathrm{kyrs}$, but we prefer the 18 kyrs value for reasons given above. We find the same pattern for the 2 and 4 Ma calculations using the 18 kyrs value. Overall, the pattern of summed throwrates for the last 18 kyrs cannot have produced the pattern of summed finite throws; the throw-rates have increased through time, especially on the centrally-located faults. This fact is consistent with the suggestion in Section 5 and the hypothesis in Fig. 1b that the faults may be at an early stage of throw profile readjustment following the initiation of interaction. In the following section we investigate when the change in throw-rates occurred and when the investigated faults started to grow. 
(a)
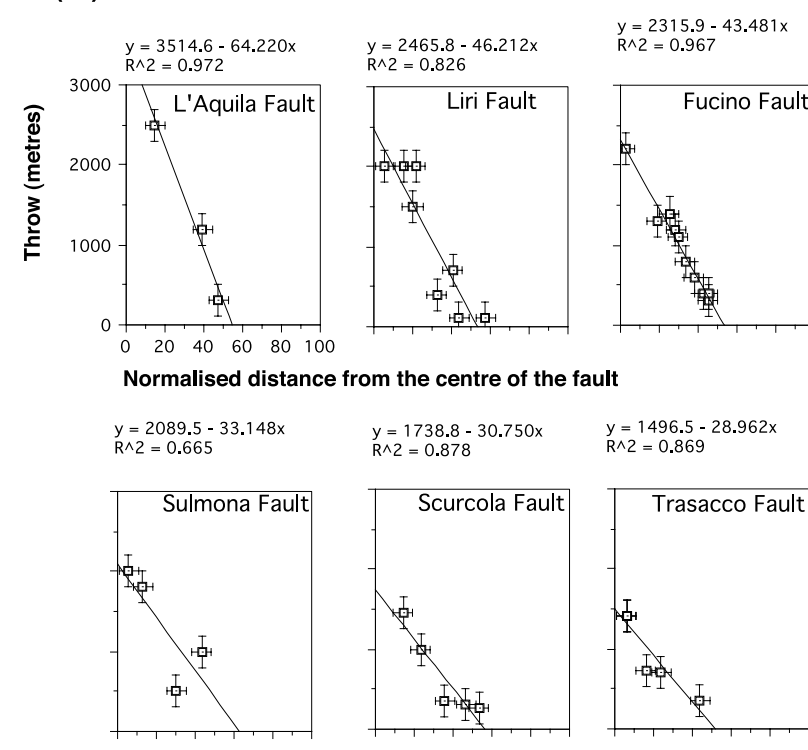

$y=1821.9-38.772 x$
$R^{\wedge} 2=0.681$

$y=1843.2-36.021 x$

$y=1757.1-34.690 x$
$R^{\wedge} 2=0.988$
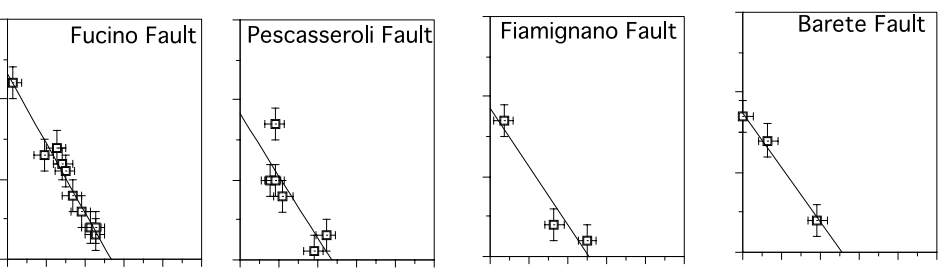

(b)

$y=0.12358$
$R \wedge 2=0.880$

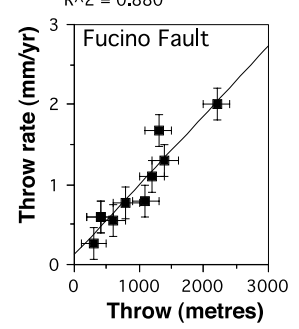

$y=1738.8-30.750 x$

$y=1496.5-28.962 x$
$R \wedge 2=0.869$

$y=1365.7-18.359 x$
$R \wedge 2=0.736$

$y=1057.9-14.517 x$
$R^{\wedge} 2=0.988$

$y=930.56-15.859 x$
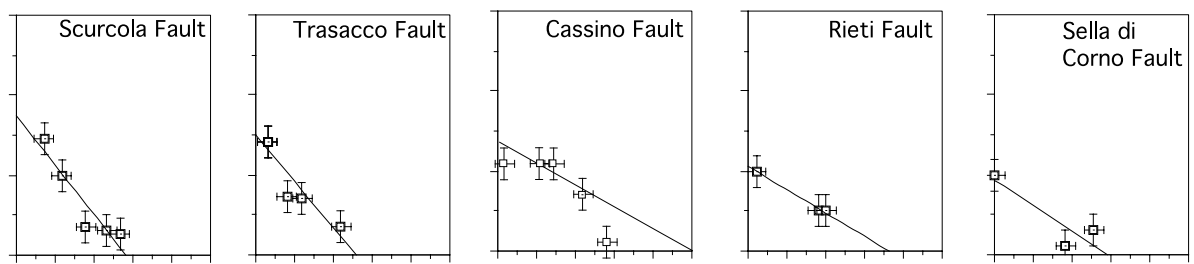

$y=-8.9124 e-2+6.4650 e-4 x$
$R^{\wedge 2}=0.961$

$y=-0.11278+5.9455 e-4 x$
$R \wedge 2=0.914$

$y=-9.4142 e-2+5.3311 e-4 x$
$R \wedge 2=0.793$

$y=0.20524+4.7137 e-4 x$
$R \wedge 2=0.908$

$y=9.4322 e-2+4.2915 e-4 x$
$R^{\wedge} 2=0.985$
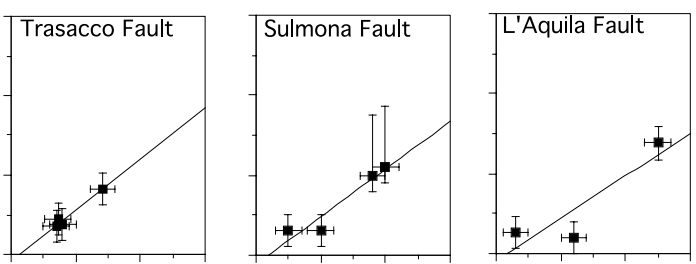

Liri Fault

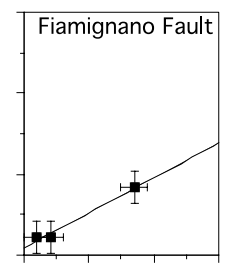

$y=9.9212 e-2+4.1525 e-4 x$

$y=0.19864+3.9633 e-4 x$

$y=1.2687 e-2+3.1567 e-4 x$

$y=0.14000+2.6000 e-4 x$

Pescasseroli Fault
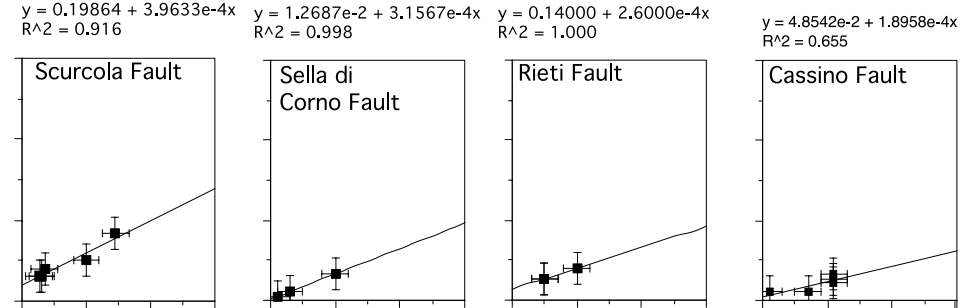

$y=0.34928+8.6331 e-5 x$

Cassino Fault
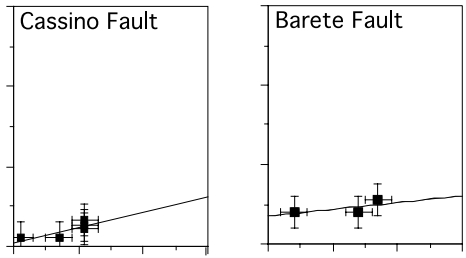

(c) $y=2.1826-3.9274 \mathrm{e}-2 \mathrm{x}$
$\mathrm{R}^{\wedge} 2=0.918$

$y=1.8797-3.7186 e-2 x$

$y=1.4325-2.3981 e-2 x$
$R \wedge 2=0.909$

$y=1.2265-2.3912 \mathrm{e}-2 \mathrm{x}$
$\mathrm{R}^{\wedge} 2=0.895$

$y=0.82688-1.4987 e-2 x$

$y=0.86853-1.4897 \mathrm{e}-2 x$ 4 Fucino Fault
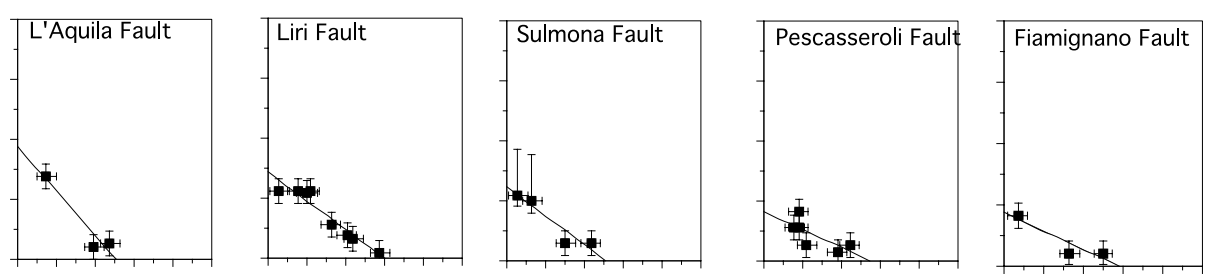

Normalised distance from the centre of the fault

$y=0.89673-1.2446 e-2 x$

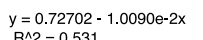

$y=0.30994-5.1259 e-3 x$

$y=0.3484$
$R \wedge 2=0.94$
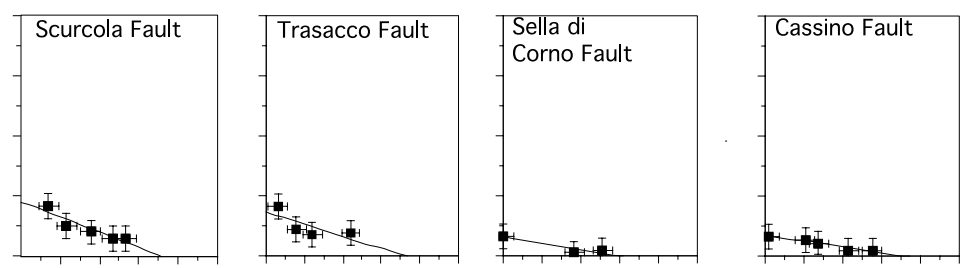

$y=0.41506-3.7745 e-3 x$

$y=0.50714-3.3571 e-3 x$

\section{Rieti Fault}

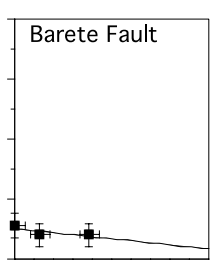




\subsection{Ages for the initiation of extensional faulting and} change in throw-rates in the Lazio-Abruzzo Apennines

To investigate when the faults started to grow we divide the maximum throw by the maximum throw-rate for each fault, for now assuming that the throw-rate has remained constant through time, ignoring the conclusions of Section 6.1. The calculations suggest ages of fault initiation ranging between ca. 1.0 and $3.3 \mathrm{Ma}$ (Table 2 and Fig. 14) (0.9$2.6 \mathrm{Ma}$ if throw-rates are calculated over $14 \mathrm{kyrs}$ ). However, we think this is misleading because of the clear inverse relationship between implied initiation age (actually maximum throw divided by maximum throw-rate) and distance from the ends of the fault array. The assumption of constant rates through time used in this calculation is incorrect, producing misleading 'initiation ages' (Section 6.1). A similar inverse relationship results if this calculation were carried out for the hypothetical fault system in Fig. 1b where we know throw-rates have increased with time. The inverse relationship in Fig. 14a results because the increase in throw-rate values relative to throw values was greater towards the centre of the array (Fig 10d). This produces apparently young initiation ages for centrally-located faults if constant throw-rates through time are assumed. However, on the distal faults where little or no change in throw-rates is implied by Fig. 10d (see also Fig. 1e), the calculation may well provide an accurate measure of the actual initiation age for the faults. Dividing the maximum throws by the maximum throw-rates for the distal Rieti, Leonessa and Cassino Faults, ages for initiation of extensional faulting of 2.5-3.3 Ma are suggested (see Fig. 14a for error estimates).

Our interpreted age of initiation of extensional faulting (2.5-3.3 Ma) is consistent with stratigraphic studies which show that the Rieti (distal) and Fucino (central) extensional basins contain sediments at least as old as $2.5 \mathrm{Ma}$ (Patacca et al., 1990; Cipollari and Cosentino, 1997; Cipollari et al., 1997; Cavinato and De Celles, 1999; Cavinato et al., 2002). The age is also consistent with the idea that extension started 2-4 Myrs after the onset of thrusting (from stratigraphic studies, see Cavinato and De Celles (1999); their fig. 3), with thrusting initiating at ca. 6.5 Ma when the continental promontory of the Adria plate entered the subduction zone (see Lucente et al. (1999); their fig. 9).

It is obvious that, at a large scale, extension has migrated east with the Neogene ocean spreading in the Tyrrhenian Sea and now inactive extensional basins on the west coast of Italy (Cavinato and De Celles, 1999). However, we follow Roberts et al. (2002) and do not believe that there is evidence for such migration at a smaller scale within the area we show in Fig. 2b. The fill to the extensional basin in the hanging wall of the L'Aquila fault in the NE of the region contains Lower Pleistocene Mammuthus (Archidiskodon) meridionalis vestinus (Azzaroli, 1977; Esu et al., 1992), which overlie at least $200 \mathrm{~m}$ of older continental deposits. This implies hanging wall sedimentation at a similar time to that of the early parts of the syn-rift fill to the Rieti basin, which is three fault blocks across strike, closer to the Tyrrhenian Sea. Indeed, there is no correlation between implied initiation age and distance across strike, supporting the above (Roberts et al., 2002, their fig. 3). We would like to test this with detailed stratigraphic data. However, the bases of the hanging wall basins have, to our knowledge, not been penetrated by boreholes so the actual ages of initiation of fault activity cannot be dated in this way; reported ages are for onlapping sediments on the edges of basins which are necessarily younger than the first sediment infills (see Cavinato and De Celles, 1999; Cavinato et al., 2002). Also, some of the extensional basins in the high topography of the Apennines (e.g. the Campo Imperatore basin) may not have been sites of significant sediment accumulation early in their history due to the limited extent of drainage catchments; the stratigraphic record of early basin subsidence may be very difficult to recognise in these basins. Overall, we think the interpreted age of 2.5-3.3 Ma for the initiation of extensional faulting may well apply to all the faults we have considered.

Note that the throw-rates on the distal Rieti, Leonessa and Cassino Faults cannot have slowed with time. A decrease in throw-rates with time would produce predicted throws that are lower than measured throws, the opposite of what we generally find in Fig. 10. Indeed, a decrease in throw-rates with time on distal faults is inconsistent with numerical fault growth simulations (Cowie, 1998). Such models show that throw-rates on distal faults must be maintained whilst those for central faults increase if localised fault systems are to develop whilst maintaining constant regional strain rates.

Accepting that the initiation age for the extensional faulting is $2.5-3.3 \mathrm{Ma}$ for all the faults, we can make a crude estimate of when throw-rates increased. Fig. 1e suggests that throw-rates on the central fault will increase when the faults start to interact because Fig. 1b shows that the central fault must develop a throw that is consistent with that expected for the longer fault array (see Fig. 1a). To calculate the time when throw-rates increased we use the finite throw values associated with the central Fucino $(2.2 \mathrm{~km})$ and distal Leonessa Faults $(1.0 \mathrm{~km})$. We also use the apparent initiation ages for the central faults from Fig. $14 \mathrm{a}$ and also the value of 3.24 Ma for the distal faults that comes from regression of the apparent ages. We assume the central and distal faults had similar throw-rates prior to throw-rate increases as postulated in Fig. 1. We also assume

Fig. 13. Graphs showing the relationships between throw, throw-rate and distance along a fault for individual faults in Lazio-Abruzzo. The graphs are arranged so that the highest slope values for regression lines are on the left, decreasing towards the right in two rows. The slope and $y$-intercept values are used in Figs. 12 and 15 . Throw errors are $\pm 200 \mathrm{~m}$. Throw-rate errors shown are usually $\pm 0.2 \mathrm{~mm} / \mathrm{yr}$ although actual errors are almost certainly smaller than this. 
Table 2

Implied initiation ages for faulting calculated by dividing the throw maxima by the throw-rate maxima for each fault. * Faults for which throw values are poorly constrained. $\wedge$ Fault for which the throw-rate is only a maximum value. Distances are measured from Fig. 8. Errors (shown in Fig. 14) are $\pm 10 \%$ of the throwrate and $\pm 200 \mathrm{~m}$ throw

\begin{tabular}{|c|c|c|c|c|}
\hline Fault & Distance from the nearest end of array $(\mathrm{km})$ & Throw-rate maximum (mm/yr) & Throw maximum (m) & Implied initiation age (Ma) \\
\hline Rieti & 11.00 & 0.40 & 1000.00 & 2.50 \\
\hline Leonessa & 12.00 & 0.40 & 1000.00 & 2.50 \\
\hline Cassino & 16.00 & 0.33 & 1100.00 & 3.33 \\
\hline Sella di Corno & 33.00 & 0.33 & 1000.00 & 3.03 \\
\hline Barete & 33.00 & 0.55 & 1600.00 & 2.91 \\
\hline Cinque Miglia & 41.00 & 0.38 & 1000.00 & 2.63 \\
\hline Fiamignano & 42.00 & 0.83 & 1700.00 & 2.05 \\
\hline Pescasseroli & 43.00 & 0.83 & 1700.00 & 2.05 \\
\hline Carsoli* & 48.00 & 0.38 & 800.00 & 2.11 \\
\hline L'Aquila & 56.00 & 1.38 & 2200.00 & 1.59 \\
\hline Maiella^ $^{\wedge}$ & 56.00 & 0.83 & 2100.00 & 2.53 \\
\hline Scurcola & 58.00 & 0.83 & 1455.00 & 1.75 \\
\hline Trasacco & 59.00 & 0.83 & 1415.00 & 1.70 \\
\hline Campo Imperatore* & 62.00 & 1.10 & 2200.00 & 2.00 \\
\hline Liri & 71.00 & 1.10 & 2000.00 & 1.82 \\
\hline Fucino & 75.00 & 2.00 & 2200.00 & 1.10 \\
\hline
\end{tabular}

linear time versus displacement curves. Fig. 14b, which is similar to Fig. 1e, suggests an increase in centrally-located throw-rates at about $0.7 \mathrm{Ma}$. This is consistent with our hypothesis from Section 5.2 that throw-rates have increased only recently, but before the demise of the last glaciation, and throw-profile readjustment is at an early stage. However, note that a gradual increase in throw-rates on the Fucino Fault associated with a gradual increase in fault interaction implies an older age for the onset of fault interaction, and this is certainly possible.

Available stratigraphic and seismic reflection data from the hanging wall basin to the Fucino fault are consistent with our preferred initiation ages and confirm that throwrates have increased at a time similar to that which we suggest (Cavinato et al., 2002): (1) syn-rift-sedimentation started in the Middle(?)-Upper Pliocene; (2) the Pleistocene-Holocene sequence in the hanging wall of the Fucino fault is about two times thicker than the underlying Upper Pliocene sequence even though the time periods are similar; (3) a transition from overfilled to underfilled basin geometries occurs through time, implying an increase in the hanging wall subsidence rate if sediment flux remained constant. The time constraints available to Cavinato et al. (2002) are insufficiently detailed to constrain whether throw-rates increased gradually or exhibited a step function to a higher rate. Because the throw-rates may have increased gradually, we do not think it is sensible to propose any causal link between the increase in throw-rates and the beginning of a new extensional stress field that others have suggested for southern Italy at around 0.7 Ma (Pantosti et al., 1993; Westaway, 1993; Hippolyte et al., 1994; Galadini, 1999), especially as the timing of this proposed new extensional stress field is at least in part based on a calculation where throws are divided by throw-rates.

\section{Spatial variations in the growth rates of faults}

Fig. $1 \mathrm{~b}$ and $\mathrm{d}$ shows that the greatest throw-rates are exhibited by faults in the centre of the array. For the LazioAbruzzo Apennines, we note that the faults with greatest maximum throw-rates are positioned in the centre of the region, with values decreasing towards the NW and SE (Fig. 8). Quantitative analysis shows the above to be correct (Fig. $15 \mathrm{a}$ ), and the $R^{2}$ value of 0.685 suggests that there is a relatively strong relationship between maximum throw-rate and distance along the array. There is a ca. six-fold increase in maximum throw-rates between centrally-located faults $(2 \mathrm{~mm} / \mathrm{yr}$ ) and distal faults (ca. $0.33 \mathrm{~mm} / \mathrm{yr}$ ). This is consistent with the pattern shown in Fig. $1 \mathrm{~b}$.

As described above, the throw-rates vary along individual faults with maxima and minima coinciding geographically with throw maxima and minima. We note positive correlations between throw and throw-rates (Fig. 13b). However, different slopes exist for this relationship for different faults. For a portion of a fault of given throw-say $500 \mathrm{~m}$ - the throw-rates vary by a factor of about six $(0.5-$ $0.08 \mathrm{~mm} / \mathrm{yr}$ for $500 \mathrm{~m}$ throw). Thus, growth of a fault seen on a two-dimensional cross-section of given finite throw can occur at different rates within the same region, and is not solely related to the extension rate across the region (compare with Nicol et al. (1997)). This is explained by the fact that given throw values occur at different places along faults that share similar lengths but different maximum throws. For example, $500 \mathrm{~m}$ throw values exist at between about 25 and $45 \%$ of the total fault length away from the centre of the faults (see Figs. 8 and 13a). Furthermore, quantitative analysis shows that slope values for the throw versus throw-rate relationships are correlated with distance along the overall array (Fig. 15b), increasing 
(a)

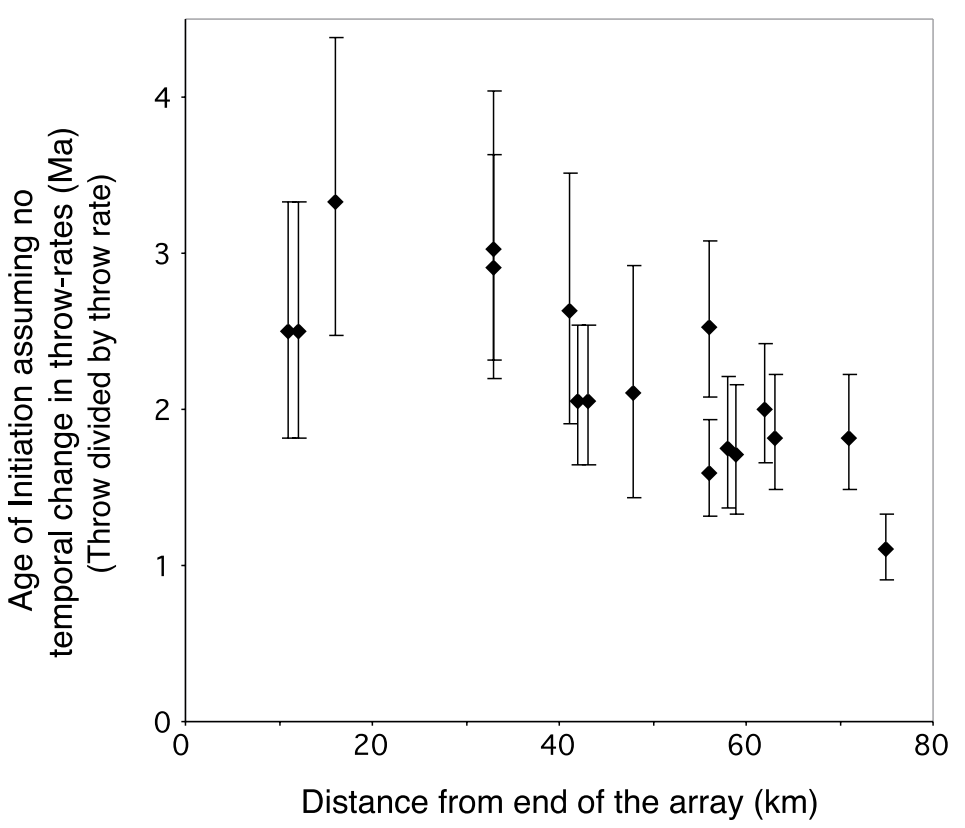

(b)

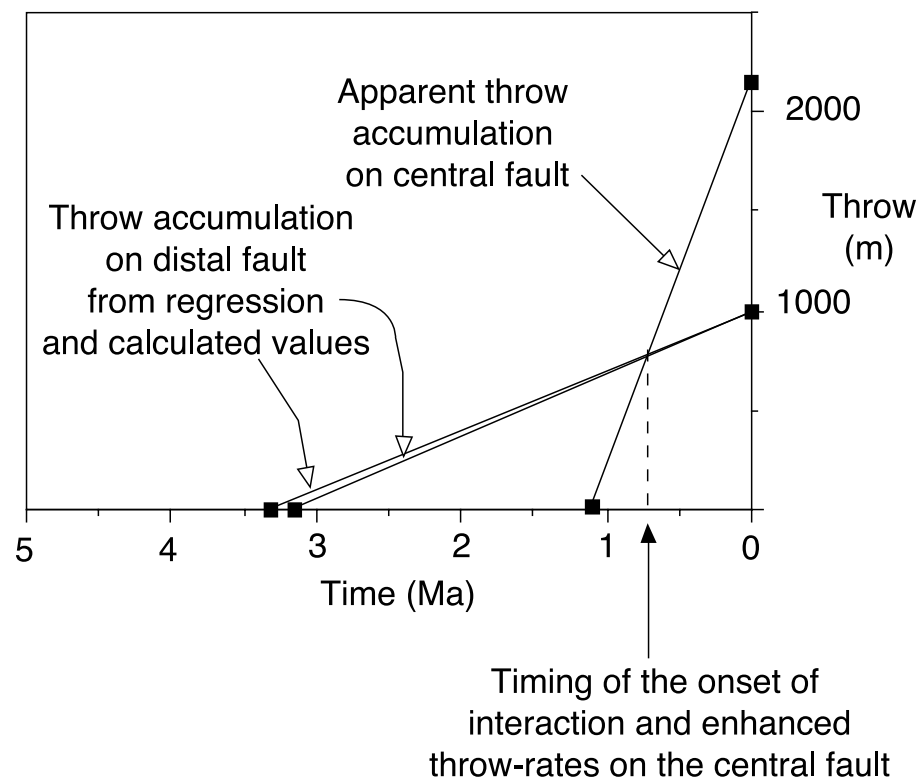

Fig. 14. (a) Graph showing the implied age of initiation of extension for faults in the Lazio-Abruzzo Apennines against distance along the fault array, assuming no temporal change in deformation rates. The ages are calculated by dividing the measured maximum throws by the maximum throw-rates for each fault (see Fig. 8 and Table 2). Note the inverse relationship with distance from the end of the array. We argue that this inverse relationship is an artefact produced by deformation rates increasing with time on central faults, contrary to the assumption used in this graph. The evidence showing that this is an artefact is in Fig. $10 \mathrm{~d}$, which shows that the increase in deformation rates relative to throws increases with proximity to the centre of the fault array. Thus, the throw-rates on central faults have changed most so their apparent initiation ages are decreased from the actual age by the greatest amount. We argue that true initiation ages can only be calculated by dividing the throw by the throw-rate for distal faults, because Fig. 10d shows that the throw-rates have increased least with time on these faults or not at all. Thus, we interpret the initiation age for extension in the Lazio-Abruzzo Apennines to be 2.5-3.3 Ma, with regression of the data (not shown) indicating an age of $3.24 \mathrm{Ma}$. (b) Calculation showing the time when throw-rates increased on the central faults due to the onset of fault interaction assuming linear time versus slip histories (see text in Section 6 for discussion).

towards the centre of the array. Instead of being controlled solely by the regional extension rate, the rates of fault growth are controlled by a combination of their position within the overall fault array and the regional extension rate (see Fig. 1b). Again, the above patterns are consistent with Fig, $1 b$.

Fig. $1 \mathrm{~b}$ and $\mathrm{d}$ also show that centrally-located faults will have progressively steeper throw-rate versus distance 
(a)

(a) $y=0.23878 * 10^{\wedge}(1.0144 \mathrm{e}-2 \mathrm{x}) \quad \mathrm{R}^{\wedge} 2=0.685$

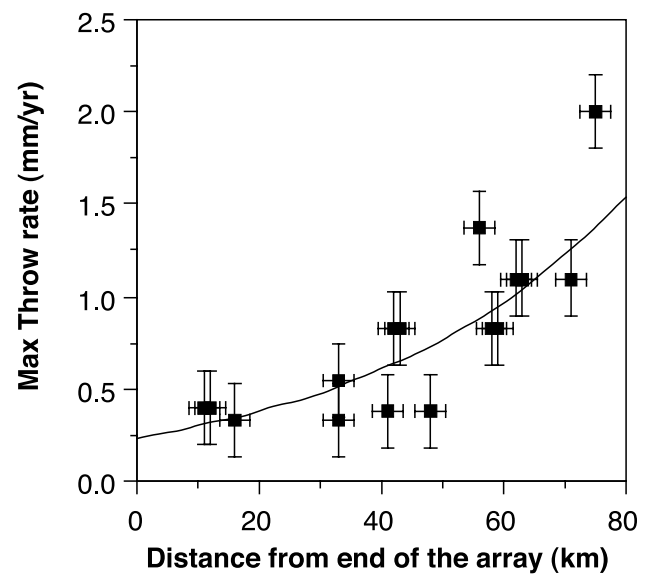

(c) $\quad y=2.0953 e-3^{*} 10^{\wedge}(1.5759 e-2 x) \quad R^{\wedge} 2=0.742$

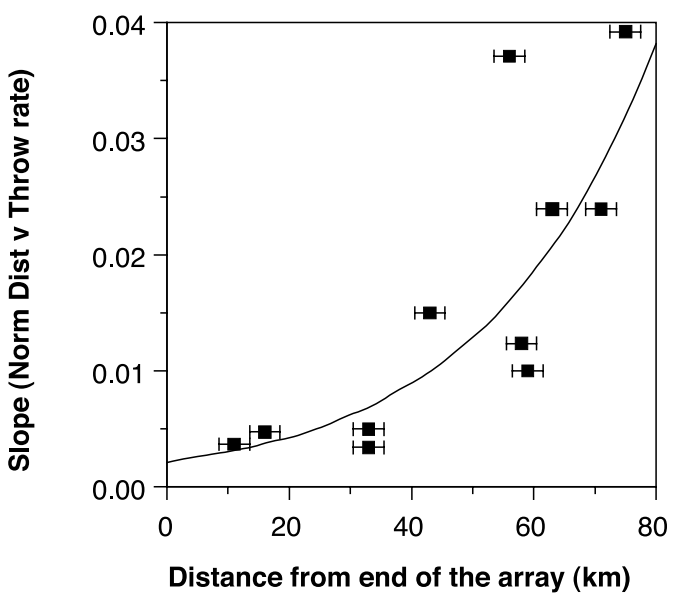

(b)

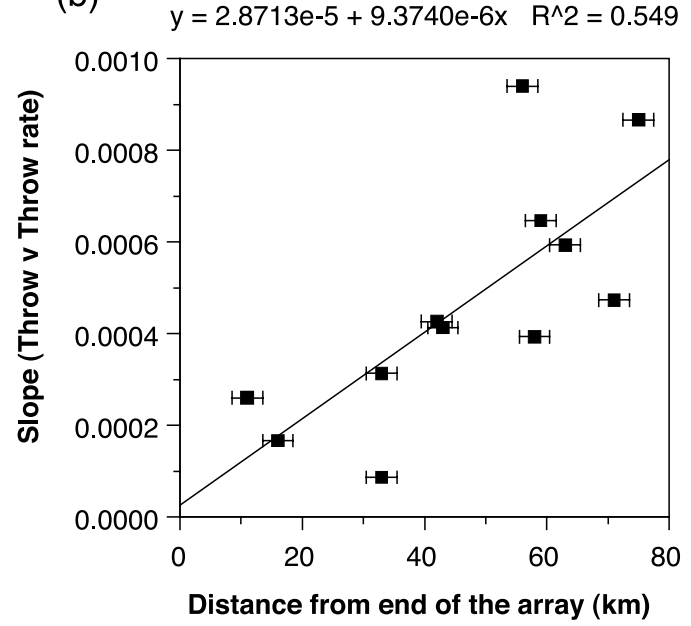

(d)

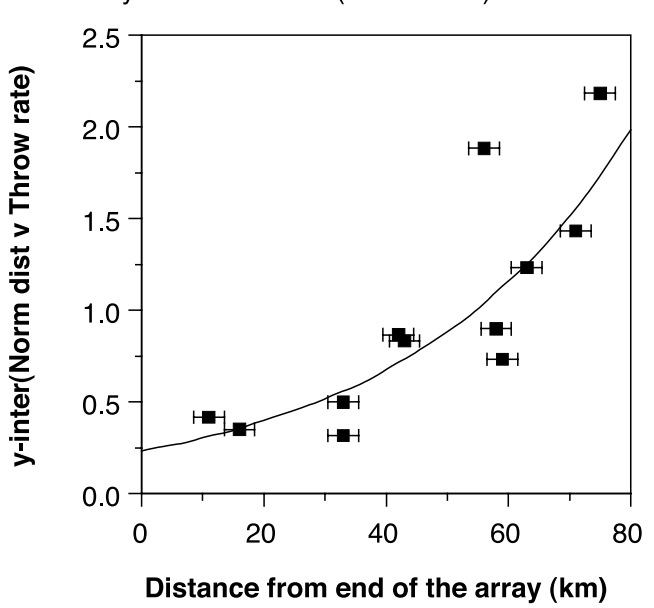

Fig. 15. Graphs showing how throw-rate related parameters vary along the strike of the Lazio-Abruzzo Apennines. Data from Table 2 and the regression equations in Fig. 13. The Campo Imperatore, Maiella and Carsoli faults have been omitted because some values are relatively poorly constrained (see Table 2). Throw-rate errors shown are $\pm 0.2 \mathrm{~mm} / \mathrm{yr}$ although actual errors are almost certainly smaller than this. The maximum throw-rates, throw-rate gradients and throw versus throw-rate relationships on individual faults increase towards the centre of the fault array. The relatively high $R^{2}$ values show these relationships are relatively strong (compare with Figs. 1 and 12).

gradients than distal ones. For the Lazio-Abruzzo Apennines, we have found an inverse correlation between normalised distance from the fault centre and throw-rates for individual faults (Fig. 13c). Again, different slopes for this relationship exist for different faults. Quantitative analysis shows that slope values for this relationship are correlated with distance along the overall array (Fig. 15c), increasing towards the centre of the array. The $R^{2}$ value (0.742) shows that this is a relatively strong relationship. The same is true for values for the $y$-intercept for this relationship (Fig. 15d), ( $R^{2}$ value of 0.747$)$. This demonstrates that not only are the rates of fault growth at individual localities controlled by their position within the overall fault array, but so are throw-rate gradients, consistent with Fig. $1 b$.

The above demonstrates that for points at given normalised distances along the individual faults, throw-rates are higher on centrally located faults. Given time, and no further change in throw-rates, centrally located faults will develop the largest finite throws and may eventually gain higher values for the throw/length ratio (depending on their initial lengths at the start of interaction).

Overall, an early stage of faulting with fault growth rates uncorrelated with distance along the array seems to have given way to the present situation where they increase towards the centre of the array. The increase in throw-rates occurred as recently as $0.7 \mathrm{Ma}$, with throwrates increasing by a factor of about six through time on the centrally-located Fucino fault. Thus, growth rates and the throw/length ratios change with time and fault growth is not self-similar following fault interaction. The non-self-similar fault growth is most pronounced on centrally-located faults. We suggest this throw profile readjustment is clear evidence for interaction between these crustal scale soft-linked faults in the manner described by Cowie and Roberts (2001). Interaction is 
occurring even though the faults are not physically linked by slip surfaces, forming a soft-linked array. The fault system appears to have just entered into Stage 2 of the fault growth model in Fig. 1b.

\section{Discussion}

We have shown that deformation rates are higher on centrally-located faults in the studied fault array and that the rates on centrally-located faults have increased with time. This is consistent with the results of Mansfield and Cartwright (2001) in their study of analogue models of extensional fault systems, of Cowie (1998) in her computer models of extensional fault growth, and of McLeod et al. (2000) and Contreras et al. (2000) who study seismic reflection data illustrating normal fault growth from the North Sea and Lake Malawi, respectively. All four of these studies show that such a pattern, where centrally-located faults slip most rapidly, develops through time. In the examples given by Cowie (1998) and McLeod et al. (2000) regional strain rates were maintained despite the increase in slip-rate on the centrally-located faults through death of other faults located across strike in the hanging wall and footwall (see also Jackson (1999)). Cowie and Roberts (2001) explain why such slip-rate increases are associated with the death of other faults across-strike. Faults across strike may also have died in Lazio-Abruzzo. The southwest of the region contains four faults that show no late Quaternary offset or large magnitude historical earthquakes (Roberts et al., 2002).

The fact that deformation rates are commonly higher on centrally located faults has important implications for seismic hazards. If deformation rates control earthquake frequencies (Fig. 1f), our findings imply that seismic hazards must also vary along the strike of the LazioAbruzzo Apennines fault array. The faults are known to rupture in large magnitude normal faulting earthquakes (1915 Fucino Earthquake; Ms 6.9-7.0; 33,000 fatalities). Such earthquakes involve coseismic slip increments of about a metre. Our analysis implies that the amount of slip in the last 18 kyrs shows a spatial ca. six-fold increase from the distal to the centrally-located faults. Thus, if the 2 and $0.33 \mathrm{~mm} / \mathrm{yr}$ throw-rates at the central points of the Fucino (central) and Cassino (distal) faults continue, 36 and $6 \mathrm{~m}$ of slip will accumulate in these positions in the next $18 \mathrm{kyrs}$. This implies a six-fold increase in the number of faultspecific large magnitude earthquakes in an $18 \mathrm{kyr}$ time period between the Cassino fault and the Fucino fault, assuming that all surface slip occurs during similar-sized large earthquakes. Put another way, the implied average fault-specific earthquake recurrence intervals vary from ca. 500 years to ca. 3000 years between Fucino and Cassino when averaged over $18 \mathrm{kyrs}$, assuming $1 \mathrm{~m}$ slip-events. This spatial variation in implied seismic hazard has not been reported elsewhere. In an attempt to quantify this spatial variation in seismic hazard, a second paper uses this type of reasoning to assess and map the seismic hazards in LazioAbruzzo. The postulated change in throw-rates following the initiation of interaction implies a different spatial pattern of hazard existed prior to interaction, where hazard did not increase with proximity to the centre of the fault array. Thus, globally, different spatial seismic hazard patterns may exist for normal fault systems depending on the stage reached in the growth-linkage-interaction process.

Our findings concerning growth of the fault system are consistent with the hypothesis of Cowie and Roberts (2001) and are similar to those presented by Cowie (1998) who presented the results of a numerical simulation of fault growth. This model maintains constant extension rate boundary conditions and demonstrates both an increase in the growth rates of some faults with time and higher growth rates on centrally-located along-strike faults resulting from the initiation of elastic interaction between neighbouring along-strike faults. No temporal variations in sub-crustal processes are involved. The model depends on the fact that after a critical value of strain and fault interaction, earthquakes on one fault change the stress state on along strike faults in such a way as to promote failure (e.g. Hodgkinson et al., 1996) leading to higher throw-rates on centrally-located faults. This process may well be important in Lazio-Abruzzo and this should be noted when attempts are made to calculate probabilities of earthquake occurrence (compare with McCalpin and Nishenko (1996)).

Increases in growth rates on normal faults with time have been discussed by several authors (see Gupta et al. (1998) for a review), usually with an increase in the regional extension rates with time invoked as explanation. That we find evidence for increased throw-rates only on centrallylocated faults in an array supports the idea that the increase is best explained by increasing elastic interaction rather than increasing regional extension rates, as suggested by Gupta et al. (1998). It also implies that elastic fault interaction may be controlling both the deformation rates and the long-term seismic hazards in Lazio-Abruzzo. It may be possible to understand seismic hazards over timescales where elastic interaction has had time to trigger earthquakes on all faults within an array and these earthquakes have had a chance to trigger their own offspring earthquakes. Such a time period will include a large number of earthquakes, and judging from the earthquake recurrence intervals inferred above, many thousands of years. This is the subject of a second paper on Lazio-Abruzzo in this issue.

\section{Conclusions}

1. Our analysis reveals the presence of 21 major normal faults in Lazio-Abruzzo plus two others mentioned by Blumetti (1995). Of the 21 faults, 17 are active and form a soft-linked array containing parallel faults spaced only $7-15 \mathrm{~km}$ apart in places, with both en échelon and 
end-on arrangements of along-strike faults. Inactive or less active $(<0.2 \mathrm{~mm} / \mathrm{yr}$ throw-rate) faults show hundreds of metres of cumulative throw, but no recognisable geomorphic signs of post-glacial fault slip. The lengths and positions of all these major faults are confirmed by spatial variations in throw, throw-rate and slip-directions, updating data in preliminary studies by Cowie and Roberts (2001) and Roberts et al. (2002).

2. The mean fault-slip direction for localities at the centres of the active faults is $222 \pm 4^{\circ}$ at the $99 \%$ confidence level $(N=162)$, demonstrating almost pure dip-slip faulting on ca. NW-SE faults. The mean fault-slip direction for localities at the centres of the inactive (or less active) faults is $216 \pm 4^{\circ}$ at the $99 \%$ confidence level $(N=64)$, again also pure dip-slip on NW-SE faults. The directions are indistinguishable at the $99 \%$ confidence level. Assuming that the inactive faults deformed before the active ones, rotations about vertical axes-if present-must occur slowly relative to fault-normal extension; far-field stress orientations have not changed during faulting, again consistent with dip-slip rather than oblique-slip regional kinematics.

3. Throws and throw-rates summed across strike vary from maxima close to the centre of the studied region $(6.6 \pm 0.8 \mathrm{~km} ; 4.4 \pm 0.8 \mathrm{~mm} / \mathrm{yr})$ to close to zero both $\mathrm{NW}$ and SE along the strike of the Apennines. Assuming $45^{\circ}$ fault dips, these values give an indication of the variation in heave and heave rates along the fault system, allowing a comparison with values for horizontal extension from GPS $(6 \pm 2 \mathrm{~mm} / \mathrm{yr})$, although the locations of these datasets are not exactly coincident. Throw-rates are increasingly high relative to throws approaching the centre of the array, implying that throwrates have increased with time. Because the faulting is almost pure dip-slip and rates of rotation about vertical axes are likely to be small relative to fault-normal heave rates, the (a) heave directions at the centres of faults (ca. $220^{\circ}$ ), (b) the heave and (c) heave rates represent the (i) finite and instantaneous extension directions, (ii) the amount of extension and (iii) the extension rates for the last ca. 18 kyrs.

4. Maximum throws and throw-to-length relationships vary between faults and with distance along the fault array as a whole. The greatest throw values are found at the centre of the array although quantitative analysis shows variable strengths for these relationships $\left(R^{2}\right.$ values between 0.120 and 0.603 ).

5. Fault growth rates are greatest for faults located centrally within the studied fault array. The relatively high $R^{2}$ values (0.549-0.747) demonstrate relatively strong relationships between growth-rate related parameters and distance from the ends of the fault array. The maximum throw-rates show a ca. six-fold increase from the distal (e.g. Cassino fault; $0.3 \mathrm{~mm} / \mathrm{yr}$ ) to the centrallylocated faults (e.g. Fucino fault; $2 \mathrm{~mm} / \mathrm{yr}$ ).

6. The throw/length ratios for individual faults (0.035-
0.083) are higher than that for the overall array (0.014) when throws are summed across strike for percentage fault length distances similar to those in comparable global databases (Schlische et al., 1996).

7. Our throw-rate database covers most if not all the active faults in the Lazio-Abruzzo Apennines and may be used to develop maps of seismic hazard variation in a similar way to that used by the Working Group on California Earthquake Probabilities (WG99) (1999).

We use the above facts to interpret the following:

First, we suggest that an early stage of faulting, which initiated at 2.5-3.3 Ma, exhibited fault growth rates uncorrelated with distance across the array. This has given way to the present situation where they show a sixfold decrease with distance from the centre of the array and the central fault has experienced a six-fold increase in throw-rate through time. This is similar to the model in Fig. 1b. The throw/length ratios and maximum throws are adjusting to the new growth rates through non-selfsimilar fault growth, which is most pronounced on centrally-located faults. The time elapsed since this change in growth rates is relatively short, because at present, there is a weak or insignificant relationship between (1) throw/length ratios, (2) maximum throws and (3) throw-length profiles, and distance along the fault array. We suggest fault throws have not yet had time to fully adjust to the new growth rates. A calculation that assumes that the central faults had the same throw-rates as distal faults prior to interaction and linear time versus slip histories suggests throw-rates increased on central faults as recently as $0.7 \mathrm{Ma}$.

Second, the implied throw profile readjustment suggests that the 17 active crustal scale faults appear to be interacting and behaving as a larger structure which is ca. $155 \mathrm{~km}$ in length and $55 \mathrm{~km}$ across strike, despite the fact that they are not physically linked by slip-surfaces and are an example of a soft-linked array. This explains why significant strains are accumulating in the segment boundaries or relay ramps between the faults (see Morewood and Roberts, 2000). Our findings are similar to those derived from study of simulated fault systems (Cowie, 1998), and consistent with observations of scaling relationships between fault length and throw (Fig. 1).

Our findings and interpretations imply the following:

(a) Throw-rates and presumably seismic hazards vary along the strike of the studied fault system over two lengths scales: first over a 20-40 km length scale along individual faults; second over the length of the overall interacting fault array which is about $155 \mathrm{~km}$ long.

(b) Throw-rates and seismic hazards may be controlled by 
the same factors that control scaling relationships between fault throw and length, shown by our comparisons with Fig. 1. This factor may be elastic interaction due to earthquake triggering on neighbouring alongstrike faults, but could be another factor because our results do not rely on such elastic interaction.

(c) It should be possible to predict throw-rates and hence seismic hazards over long timescales containing many earthquakes with knowledge of scaling relationships between fault throws and lengths as argued by Cowie and Roberts (2001). This is because (i) such long timescales will include a complete record of slip with numerous slip increments at each point along the fault array and, (ii) spatial variation in slip-rates must conform with long-term patterns of slip described by fault scaling relationships as shown in Fig. 1. These implications are explored in a second paper on LazioAbruzzo in this issue.

\section{Acknowledgements}

This study was funded by NERC GR9/02995 and Birkbeck College (GPR), and ANPA (AMM). The Benfield Greig Hazard Research Centre at UCL is thanked for support. We thank Nigel Morewood, Ioannis Papanikolaou, Patience Cowie, Leonello Serva, Eutizio Vittori and Kerry Sieh for discussions concerning this study. We thank Dario Zampieri, Francesca Ghisetti and Jim Evans for their referees comments.

\section{References}

Allen, J., Brandte, U., Brauer, A., Hubbertens, H.-W., Huntley, B., Keller, J., Kraml, M., Mackensen, A., Mingram, J., Negendank, J., Nowaczyk, N., Oberhansli, H., Watts, W., Wulf, S., Zolitschka, B., 1999. Rapid environmental changes in southern Europe during the last glacial period. Nature 400, 740-743.

Anders, M.H., Schlische, R.W., 1994. Overlapping faults, intrabasin highs, and the growth of normal faults. The Journal of Geology 102, 165-180.

Anderson, H., Jackson, J., 1987. Active tectonics of the Adriatic region. Geophysical Journal of the Royal Astronomical Society 91, 937-983.

Armijo, R., Lyon-Caen, H., Papanastassiou, D., 1992. East-west extension and Holocene normal-fault scarps in the Hellenic arc. Geology 20, 491-494.

Armijo, R., Meyer, B., King, G.C.P., Rigo, G., Papanastassiou, A., 1996. Quaternary evolution of the Corinth rift and its implications for the Late Cenozoic evolution of the Aegean. Geophysical Journal International 126, 11-53.

Azzaroli, B., 1977. The Villafranchian stage in Italy and the PlioPleistocene boundary. G. Geol. 41, 61-79.

Bachetti, C., Blumetti, A.M., Calderoni, G., Ridolfi, M., 1990. Attività neotecttonica e paleosismicità nel settore meridionale dei Monti della Laga. Rend. Soc. Geol. It. 13, 9-16.

Bagnaia, R., D’Epifanio, A., Sylos Labini, S., 1992. Aquila and Subequan basins: an example of Quaternary evolution in Central Apennines, Italy. Quaternaria Nova 1989, 187-209.

Bagnaia, R., Blumetti, A.M., De Luca, G., Gorini, A., Marcucci, S., Marsan, P., Milana, G., Salvucci, R., Zambonelli, E., 1996. Morfo- tettonica dei rilievi a Nord della conca aquilana. Il Quaternario 9 (1), 287-292.

Baratta, M., 1910. La catastrofe sismica Calabro-Messinese (28 Dicembre 1908). Relazione alla Società Geografica Italiana, Roma, 426pp.

Benedetti, L., Finkel, R., Papanastassiou, D., King, G.C.P., Armijo, R., Ryerson, F., Farber, D., Flerit, F., 2002. Post-glacial slip history of the Sparta fault (Greece) determined by ${ }^{36} \mathrm{Cl}$ cosmogenic dating: evidence for non-periodic earthquakes. Geophysical Research Letter 29, 810.1029/2001GL014510.

Bertini, T., Bosi, C., 1993. La tettonica quaternaria della conca di Fossa (L'Aquila). Il Quaternario 6 (2), 293-314.

Biasini, A., 1966. Elementi morfotettonici, tratti da un rilievo fotogeologico, al margine dell'altopiano di Ovindoli (Abruzzo). Geol. Rom. V, 303-312.

Blumetti, A.M., 1995. Neotectonic investigations and evidence of paleoseismicity in the epicentral area of the January-February 1703, Central Italy, earthquakes. In: Serva, L., Slemmons, D.B. (Eds.), "Perspectives in Paleoseismology", Association of Engineering Geologists Bulletin, Special Publication No. 6, pp. 83-100.

Blumetti, A.M., Dramis, F., Michetti, A.M., 1993. Fault-generated mountain fronts in the central Apennines (central Italy): geomorphological features and seismotectonic implications. Earth Surface Processes and Landforms 18, 203-223.

Boncio, P., Lavecchia, G., 2000. A structural model for active extension in central Italy. Journal of Geodynamics 29, 233-244.

Boschi, E., Ferrari, G., Gasperini, P., Guidoboni, E., Smriglio, G., Valensise, G., 1995. Catalogo dei forti terremoti in Italia dal 461 a.C. al 1980. Istituto Nazionale di Geofisica-SGA Storia Geofisica Ambiente. Printed by Grafica Ragno, Ozzano Emilia, BO, Italy, 973pp.

Bosi, C., 1975. Osservazioni preliminari su faglie probabilmente attive nell'Appennino centrale. Boll. Soc. Geol. It. 94, 827-859.

Bosi, C., Messina, P., 1991. Ipotesi di correlazione fra le successioni morfolitostratigrafiche Plio-Pleistoceniche nell'Appennino Laziale-Abruzzese. Studi Geologici Camerti 1991/2, 257-263.

Bosi, V., Mercier, N., 1993. Indizi di tettonica attiva nel Lazio meridionale. Atti $11^{\circ}$ Convegno Annuale G.N.G.T.S., Roma 9-11 Dicembre 1992.

Calderoni, G., Lorenzoni, P., Ortolani, F., Pagliuca, S., Serva, L., 1991. Paleoseismological evidences at Rivisondoli, Central Apennines, Italy. Rend. Soc. Geol. It. 13, 27-32.

Carraro, F., Giardino, M., 1992. Geological evidence of recent fault evolution. Examples from Campo Imperatore (L'Aquila-central Apennines). Il Quaternario 5 (2), 181-200.

Carta Geologica d'Italia, 1939. 1:100000, 151, Alatri. Servizio Geologico d'Italia.

Carta Geologica d'Italia, 1955. 1:100000, 139, L’Aquila. Servizio Geologico d'Italia.

Carta Geologica d'Italia, 1963. 1:100000, 140, Teramo. Servizio Geologico d'Italia.

Carta Geologica d'Italia, 1966. 1:100000, 160, Cassino. Servizio Geologico d'Italia.

Carta Geologica d'Italia, 1967. 1:100000, 152, Sora. Servizio Geologico d'Italia.

Carta Geologica d'Italia, 1970. 1:100000, 138, Terni. Servizio Geologico d'Italia.

Carta Geologica d'Italia, 1970. 1:100000, 147, Lanciano. Servizio Geologico d'Italia.

Carta Geologica d'Italia, 1987. 1:100000, 144, Palombara Sabina. Servizio Geologico d'Italia.

Carta Geologica d'Italia, 1987. 1:100000, 146, Sulmona. Servizio Geologico d'Italia.

Carta Geologica d'Italia, 1990. 1:100000, 161, Isernia. Servizio Geologico d'Italia.

Carta Geologica d'Italia, 1992. 1:100000, 153, Agnone. Servizio Geologico d'Italia.

Cartwright, J.A., Trudgill, B.D., Mansfield, C.S., 1995. Fault growth by segment linkage: an explanation for scatter in maximum displacement 
and trace length data from the Canyonlands Grabens of SE Utah. Journal of Structural Geology 17, 1319-1326.

Cavinato, G.P., De Celles, P.G., 1999. Extensional basins in the tectonically bimodal central Apennines fold-thrust belt, Italy: response to corner flow above a subducting slab in retrograde motion. Geology 27, 955-958

Cavinato, G.P., Carusi, C., Dall'Asta, M., Miccadei, E., Piacentini, T., 2002. Sedimentary and tectonic evolution of Plio-Pleistocene alluvial and lacustrine deposits of the Fucino Basin (central Italy). Sedimentary Geology 148, 29-59.

Cello, G., Mazzoli, S., Tondi, E., Turco, E., 1995. Tettonica attiva in Appennino centrale e implicazioni per l'analisi della pericolosità sismica del settore della catena umbro-marchigiana-abruzzese. Studi Geologici Camerti XIII, 115-138.

Cello, G., Mazzoli, S., Tondi, E., Turco, E., 1997. Active tectonics in the Central Apennines and possible implications for seismic hazard analysis in peninsular Italy. Tectonophysics 272, 43-68.

Cipollari, P., Cosentino, D., 1997. Il sistema Tirreno-Apennino: segmentazione litosferica e propagazione del fronte apenninico. Studi Geologici Camerti 1995/2, 125-134.

Cipollari, P., Cosentino, D., Parotto, M., 1997. Modello cinematicostrutturale dell'Italia centrale. Studi Geologici Camerti 1995/2, $135-143$.

Consiglio Nazionale delle Richerche (CNR), 1986. Lithofacies map of Latium-Abruzzi and neighbouring areas, 1:250000. L. Salomone, Roma.

Consiglio Nazionale delle Richerche (CNR), 1990. Structural model of Italy, 1:500000. S.E.L.C.A. Florence.

Contreras, J., Anders, M.H., Scholz, C.H., 2000. Growth of a normal fault system: observations from the Lake Malawi basin of the east African rift. Journal of Structural Geology 22, 159-168.

Corrado, S., Di Bucci, D., Naso, G., Butler, R.W.H., 1997. Thrusting and strike-slip tectonics in the Alto Molise region (Italy): implications for the Neogene-Quaternary evolution of the central Apennine orogenic system. Journal of the Geological Society, London 154, 679-688.

Cowie, P.A., 1998. A healing-reloading feedback control on the growth rate of seismogenic faults. Journal of Structural Geology 20, 1075-1087.

Cowie, P.A., Roberts, G.P., 2001. Constraining slip rates and spacings for active normal faults. Journal of Structural Geology 23, 1901-1915.

D’Addezio, G., Masana, E., Pantosti, D., 1996. Indagini morfogeologiche e paleosismologiche lungo la faglia Aremogna-Cinque Miglia (Abruzzo meridionale). Atti $15^{\circ}$ Convegno Nazionale G.N.G.T.S., Roma 11-13 Novembre 1996.

D’Addezio, G., Pantosti, D., de Martini, P.M., 1996b. Palaeoseismologic and geomorphic investigations along the middle portion of the Ovindoli-Pezza Fault (Central Italy). Annali di Geofisica XXXIX, $663-675$.

D’Agostino, N., Speranza, F., Funiciello, R., 1997. Stili e geometrie della tettonica estensionale quaternaria nell'Appennino centrale: l'area del Gran Sasso d'Italia. Il Quaternario 10 (2), 389-394.

D’Agostino, N., Giuliani, R., Mattone, M., Bonci, L., 2001a. Active crustal extension in the central Apennines (Italy) inferred from GPS measurements in the interval 1994-1999. Geophysical Research Letters 28, 2121-2124.

D’Agostino, N., Jackson, J.A., Dramis, F., Funiciello, R., 2001b. Interactions between mantle upwelling, drainage evolution and active normal faulting: an example from the central Apennines (Italy). Geophysical Journal International 147, 475-497.

Dawers, N.H., Anders, M.H., Scholz, C.H., 1993. Growth of normal faults: displacement-length scaling. Geology 21, 1107-1110.

De Polo, C.M., Anderson, J.G., 2000. Estimating the slip rates of normal faults in the Great Basin, USA. Basin Research 12, 227-240.

Doglioni, C., 1993. Some remarks on the origin of foredeeps. Tectonophysics 228, 1-20.

Esu, D., Girotti, O., Kotsakis, T., 1992. Molluschi e vertebrati di alcuni bacini continentali dell'Appennino centrale: indicazioni biostratigrafiche e paleoecologiche. Studi Geologici Camerti 1991/2, 295-299.

Galadini, F., 1999. Pleistocene changes in the central Apennine fault kinematics: a key to decipher active tectonics in central Italy. Tectonics $18,877-894$

Galadini, F., Galli, P., 2000. Active tectonics in the central Apennines (Italy) — input data for seismic hazard assessment. Natural Hazards 22, $225-270$.

Galadini, F., Giuliani, R., 1993. Role of the structural geology analysis in the recent tectonics studies: an example from an area located SW of the Gran Sasso (central Italy). Annali di Geofisica XXXVI (1), 287-292.

Galadini, F., Messina, P., 1993a. Stratigrafia dei depositi continentali, tettonica ed evoluzione geologica quaternaria dell'alta valle del fiume Sangro (Abruzzo Meridionale). Boll. Soc. Geol. It. 112, 877-892.

Galadini, F., Messina, P., 1993b. Characterization of the recent tectonics of the upper Sangro valley (Abruzzi Apennine, central Italy). Annali di Geofisica XXXVI (1), 277-285.

Galadini, F., Salvi, S., 1990. Processamento di immagini LANDSAT per l'interpretazione strutturale in aree tettonicamente attive: un esempio del margine sud-occidentale della catena del Gran Sasso. Il Quaternario $3,15-22$.

Galadini, F., Galli, P., Giraudi, C., 1997a. Geological investigations of Italian earthquakes: new paleoseismological data from the Fucino Plain (Central Italy). Journal of Geodynamics 24, 87-103.

Galadini, F., Galli, P., Giraudi, C., 1997b. Paleosismologia della Piana del Fucino (Italia Centrale). Il Quaternario 10, 27-64.

Galadini, F., Galli, P., Giraudi, C., Molin, D., 1995. Il terremoto del 1915 e la sismicita della Piana del Fucino (Italia Centrale). Bollettino della Societa Geologica Italiana 114, 635-663.

Galadini, F., Giraudi, C., Messina, P., 1999. Nuovi dati sulla tettonica tardopleistocenica dell'Alta Valle dei Sangro (Apennino Centrale): implicazioni sismotettoniche. Il Quaternario 11 (2), 347-356.

Galli, P., Galadini, F., Moro, M., Giraudi, C., 2002. New paleoseismological data from the Gran Sasso d'Italia area (central Apennines). Geophysical Research Letters 29, 710.1029/2001GL013292.

Gawthorpe, R.L., Sharp, I., Underhill, J.R., Gupta, S., 1997. Linked sequence stratigraphy and structural evolution of propagating normal faults. Geology 25, 795-798.

Giraudi, C., 1987. Segnalazione di scarpate di faglia legate ad antichi eventi sismici ai piani di Aremogna e delle Cinque Miglia (Roccaraso, Abruzzo). Atti $6^{\circ}$ Convegno Annuale G.N.G.T.S., Roma 14-16 Dicembre 1987.

Giraudi, C., 1988a. Indagini geomorfologiche sull'area della conca di Amplero (Margine sud-orientale del Fucino-Abruzzo). Mem. Soc. Geol. It. 35, 887-892.

Giraudi, C., 1988. Datazione con metodi geologici e radiometrici di indizi di paleosismicità presenti nell'area di Roccaraso e Ovindoli (Abruzzo-Italia centrale). Atti del $7^{\circ}$ Convegno Annuale G.N.G.T.S., Roma 30 Novembre-2 Dicembre 1988.

Giraudi, C., 1988c. Segnalazione di scarpate di faglia post-glaciali nel massiccio del Gran Sasso (Abruzzo): implicazioni tettoniche, rapporti tra tettonica recente e morfologia, paleosismicità. Mem. Soc. Geol. It. 41, 627-635.

Giraudi, C., 1989a. Datazione con metodi geologici delle scarpate di faglia post-glaciali di Ovindoli-Piano di Pezza (Abruzzo-Italia centrale): implicazioni. Mem. Soc. Geol. It. 42, 29-39.

Giraudi, C., 1989b. Datazione di un evento sismico preistorico con metodi geologici e radiometrici: Piano di Aremogna e delle Cinque Miglia. In: Guidoboni, E., (Ed.), "I Terremoti Prima dell'Anno 1000”, Storia Geofisica Ambiente, Bologna, Italia, pp. 53-64.

Giraudi, C., 1995a. I detriti di versante al margin della piana del Fucino (Italia centrale): significato palaeoclimatico ed impatto antropico. Il Quaternario 8, 203-210.

Giraudi, C., 1995b. Considerations on the significance of some post-glacial fault scarps in the Abruzzo Apennines (Central Italy). Quaternary International 25, 33-45.

Giraudi, C., Frezzotti, M., 1986. Inversione pleistocenica del drenaggio in 
alta Val Roveto (Abruzzo sud-occidentale). Mem. Soc. Geol. It. 35, $847-853$.

Giraudi, C., Frezzotti, M., 1995. Paleoseismicity in the Gran Sasso Massif (Abruzzo, Central Italy). Quaternary International 25, 81-93.

Giraudi, C., Frezzotti, M., 1997. Late Pleistocene glacial events in the central Apennines, Italy. Quaternary Research 48, 280-290.

Gliozzi, E., Mazzini, I., 1998. Palaeoenvironmental analysis of Early Pleistocene brackish marshes in the Rieti and Tiberino intra-appenninic basins (Latium anf Umbria, Italy) using ostracods (Crustacea). Paleogeography, Paleoclimatology, Paleoecology 140, 325-333.

GNDT, 2000. Gruppo Nazionale per la Difesa dai Terremoti. In: Barchi, M., Galadini, F., Lavecchia, G., Messina, P., Michetti, A.M., Peruzza, L., Pizzi, A., Tondi E., Vittori, E. (Eds.), Sintesi delle conoscenze sulle faglie attive in Italia Centrale. Published by GNDT, Rome. ISBN 88900449-7-7, 62pp.

Gupta, A., Scholz, C.H., 2000. A model of normal fault interaction based on observations and theory. Journal of Structural Geology 22, 865-880.

Gupta, S., Cowie, P.A., Dawers, N.H., Underhill, J.R.U., 1998. A mechanism to explain rift-basin subsidence and stratigraphic patterns through fault array evolution. Geology 26, 595-598.

Hippolyte, J.-C., Angelier, J., Roure, F., 1994. A major geodynamic change revealed by Quaternary stress patterns in the southern Apennines (Italy). Tectonophysics 230, 199-210.

Hodgkinson, K.M., Stein, R.S., King, G.C.P., 1996. The 1954 Rainbow Mountain-Fairview Peak-Dixie Valley earthquakes: a triggered normal faulting sequence. Journal of Geophysical Research 101, 25459-25471

Hunstad, I., England, P., 1999. An upper bound on the rate of strain in the central Apennines, Italy, from triangulation measurements between 1869 and 1963. Earth and Planetary Science Letters 169, 261-267.

Jackson, J.A., 1999. Fault death: a perspective from actively deforming areas. Journal of Structural Geology 21, 1003-1010.

Jackson, J.A., White, N.J., 1989. Normal faulting in the upper continental crust: observations from regions of active extension. Journal of Structural Geology 11, 15-36

Jaurand, E., 1992. Les moraines failles du Gran Sasso d'Italia (Apennin Abruzzais): Intéret geomorphologique et néotectonique. Geographie Physique et Environnement 44, 10-29.

Jolivet, L., Facenna, C., Goffe, B., Mattei, M., Rossetti, F., Brunet, C., Storti, F., Funiciello, R., Cadet, J.-P., d'Agostino, N., Parra, T., 1998. Midcrustal shear zones in postorogenic extension: example from the northern Tyrrhenian Sea. Journal of Geophysical Research 103, 12 , 123-12,160.

Lucente, F.P.C., Chiarabba, G., Cimini, B., 1999. Tomographic constraints on the geodynamic evolution of the Italian region. Journal of Geophysical Research 104, 20,307-20,327.

Mansfield, C., Cartwright, J., 2001. Fault growth by linkage: observations and implications from analogue models. Journal of Structural Geology 23, 745-763

Margottini, C., Screpanti, A., 1988. Temporal evolution of the seismic crisis related to the 13th January 1915, Avezzano earthquake. In: Margottini, C., Serva, L. (Eds.), Historical seismicity of central-eastern Mediterranean region, Proceedings of the 1987 ENEA-IAEA International Workshop, ENEA, Roma, pp. 185-193.

Mariotti, G., Capotorti, F., 1988. Analisi ed interpretazione di alcuni elementi tettonici recenti nella media Valle del Salto (Rieti). Rend. Soc. Geol. It. 11, 79-84

Mattei, M., Funiciello, R., Kissel, C., 1995. Palaeomagnetic and structural evidence for Neogene block rotations in the central Apennines, Italy. Journal of Geophysical Research 100, 17,863-17,883.

Mattei, M., Kissel, C., Funiciello, R., 1996. No tectonic rotation of the Tuscan Tyrrhenian margin (Italy) since late Messinian. Journal of Geophysical Research 101, 2835-2845.

McCalpin, J.P., Nishenko, S.P., 1996. Holocene paleoseismicity, temporal clustering, and probabilities of future large $(M>7)$ earthquakes on the Wasatch fault zone, Utah. Journal of Geophysical Research 101, $6233-6253$.
McLeod, A., Dawers, N.H., Underhill, J.R., 2000. The propagation and linkage of normal faults: insights from the Strathspey-Brent-Statfjord fault array, northern North Sea. Basin Research 12, 263-284.

Miccadei, E., Cavinato, G.P., Vittori, E., 1992. Elementi neotettonici della conca di Sulmona. Studi Geologici Camerti 1992/1, 165-174.

Michetti, A.M., Serva, L., 1991. New data on the seismotectonic potential of the Leonessa fault area (Rieti, Central Italy). Rend. Soc. Geol. Ital. 13 (1990), 17-26.

Michetti, A.M., Brunamonte, F., Serva, L., Whitney, R.A., 1995. Seismic hazard assessment from paleoseismological evidence in the Rieti Region (Central Italy). In: Serva, L., Slemmons, D.B. (Eds.), "Perspectives in Paleoseismology", Association of Engineering Geologists Bulletin, Special Publication No. 6, pp. 63-82.

Michetti, A.M., Brunamonte, F., Serva, L., Vittori, E., 1996. Trench investigations of the 1915 Fucino earthquake fault scarps (Abruzzo, Central Italy): geological evidence of large historical events. Journal of Geophysical Research 101, 5921-5936.

Michetti, A.M., Serva, L. Vittori, E., 2000b. ITHACA Italy Hazard from Capable Faults: a database of active faults of the Italian onshore territory. CD-Rom and explicative notes, ANPA (copies available from E. Vittori: vittori@anpa.it).

Michetti, A.M., Ferreli, L., Esposito, E., Porfido, S., Blumetti, A., Vittori, E., Serva, L., Roberts, G.P., 2000a. Ground effects during the September 9, $1998 \mathrm{ML}=5.5$ Lauria Earthquake in southern Italy and the seismic potential of the "aseismic" Pollino region: preliminary report. Seismological Research Letters 71, 31-46.

Montone, P., Amato, A., Pondrelli, S., 1999. Active stress map of Italy. Journal of Geophysical Research 104, 25,595-25,610.

Morewood, N.C., Roberts, G.P., 1999. Lateral propagation of the South Alkyonides normal fault segment, central Greece: its impact on models of fault growth and displacement-length relationships. Journal of Structural Geology 21, 635-652.

Morewood, N.C., Roberts, G.P., 2000. The geometry, kinematics and rates of deformation within an en échelon normal fault segment boundary, central Italy. Journal of Structural Geology 22, 1027-1047.

Morley, C.K., 1999. Patterns of displacement along large normal faults: implications for basin evolution and fault propagation, based on examples from east Africa. Bulletin of the American Association of Petroleum Geologists 83, 613-634.

Nicol, A., Walsh, J.J., Watterson, J., Underhill, J., 1997. Displacement rates of normal faults. Nature 390, 157-159.

Nijman, W., 1971. Tectonics of the Velino-Sirente area, Abruzzi, central Italy. Koninkl. Nederl. Akademie van Wetenschappen-Amsterdam. B.74, No.2, pp 156-184.

Oddone, E., 1915. Gli elementi fisica del grande terremoto marsicano fucense del 13 Gennaio 1915. Boll. Soc. Sismol. Ital. 19, 71-215.

Pantosti, D., Schwartz, D.P., Valensise, G., 1993. Paleoseismology along the 1980 surface rupture of the Irpinia Fault: implications for earthquake recurrence in the Southern Apennines, Italy. Journal of Geophysical Research 98, 6561-6577.

Pantosti, D., D'Addezio, G., Cinti, F., 1996. Paleoseismicity of the Ovindoli-Pezza fault, central Apennines, Italy: a history including a large, previously unrecorded earthquake in the Middle Ages (8601300 A.D.). Journal of Geophysical Research 101, 5937-5960.

Patacca, E., Sartori, R., Scandone, P., 1990. Tyrrhenian Basin and Apenninic Arcs: kinematic relations since late Tortonian times. Mem. Soc. Geol. It. 45, 425-451.

Piccardi, L., Gaudemer, Y., Tapponier, P., Boccaletti, M., 1999. Active oblique extension in the central Apennines (Italy): evidence from the Fucino region. Geophysical Journal International 139, 499-530.

Postpischl, D. (Ed.), 1985. Atlas of Isoseismal Maps of the Italian Earthquakes. C.N.R., Quaderni de "La Ricerca Scientifica", 114(2A), 164pp.

Raffy, J., 1982. Orogénese et dislocations quaternaires du versant tyrrenien des Abruzzes (Italie Centrale). Re. de Geol. Din. et de Geogr. Phys. 23 (1), 55-72. 
Raffy, J., 1983. Le versant tyrrhénien de l'Apennine Central: étude géomorphologique. C.N.R.S., Paris, 705pp.

Roberts, G.P., 1996. Variation in fault-slip directions along active and segmented normal fault systems. Journal of Structural Geology 18, $835-845$.

Roberts, G.P., Ganas, A., 2000. Fault-slip directions in central-southern Greece measured from striated and corrugated fault planes: comparison with focal mechanism and geodetic data. Journal of Geophysical Research 105, 23,443-23,462.

Roberts, G.P., Michetti, A.M., Cowie, P., Morewood, N.C., Papanikolaou, I., 2002. Fault slip-rate variations during crustal-scale strain localisation, central Italy. Geophysical Research Letters 29, 810.1029/ 2001 GL013529.

Roberts, G.P., Cowie, P., Papanikolaou, I., Michetti, A.M., 2003. Fault scaling relationships, deformation rates and seismic hazards: an example from the Lazio-Abruzzo Apennines, central Italy. Journal of Structural Geology, doi:10.1016/S0191-8141(03)00104-4.

Salvi, S., Nardi, A., 1995. The Ovindoli fault: a segment of a longer, active fault zone in Central Abruzzi, Italy. In: Serva, L., Slemmons, D.B. (Eds.), "Perspectives in Paleoseismology", Association of Engineering Geologists Bulletin, Special Publication No. 6, pp. 101-113.

Schlische, R.W., Young, S.S., Ackermann, R.V., Gupta, A., 1996. Geometry and scaling relations of a population of very small riftrelated faults. Geology 24, 683-686.

Sylos Labini, S., Bagnaia, R., D’epifanio, R., 1993. Il Quaternario del Bacino di Sulmona (Italia centrale). Quaternaria Nova III, 343-360.

Tondi, E., 2000. Geological analysis and seismic hazard in the central Apennines (Italy). Journal of Geodynamics 29, 517-533.

Tondi, E., Cello, G., Mazzoli, S., 1997. Strutture sismogenetiche in Appennino Centrale: potenziale sismico, analisi frattale e processi di crescita. Il Quaternario 10, 409-414.

Tzedakis, P.C., Andrieu, V., de Beaulieu, J.-L., Crowhurst, S., Follieri, M., Hooghiemstra, H., Magri, D., Reille, M., Sadori, L., Shackleton, N.J., Wijmstra, T.A., 1997. Comparison of terrestrial and marine records of changing climate of the last 500,000 years. Earth and Planetary Science Letters $150,171-176$.
Vezzani, L., Ghisetti, F., 1998. Carta Geologica Dell'Abruzzo, 1:100000, SELCA, Via R. Giuliani, 153, Firenze.

Vittori, E., 1994. Project of a map and database of active faults in Italy: methodological approach. In: Spagna, V., (Ed.), Proceedings of Scientific Meeting on the Seismic Protection, Giunta Regionale del Veneto, Palazzo Balbi, Venice, July 12-13 1993, pp. 119-130.

Vittori, E., Cavinato, G.P., Miccadei, E., 1995. Active faulting along the northeastern edge of the Sulmona basin, central Apennines, Italy. In: Serva, L., Slemmons, D.B. (Eds.), "Perspectives in Paleoseismology", Association of Engineering Geologists Bulletin, Special Publication No. 6, pp. 115-126.

Vittori, E., Maschio, L., Ferreli, L., Michetti, A.M., Serva, L., 1998. Carta e base delle faglie capaci per L'Italia centro-meridionale: presentazione e stato di avanzamento del progetto ITHACA. Il Quaternario 10, $305-312$.

Walsh, J.J., Watterson, J., 1988. Analysis of the relationship between displacements and dimensions of faults. Journal of Structural Geology 10, 239-247.

Westaway, R., 1992. Seismic moment summation for historical earthquakes in Italy: tectonic implications. Journal of Geophysical Research 97, 15437-15464. (correction-Journal of Geophysical Research 98 (1993), 4539).

Westaway, R., 1993. Quaternary uplift of Southern Italy. Journal of Geophysical Research 98, 21,741-21,772.

Westaway, R., Gawthorpe, R., Tozzi, M., 1989. Seismological and field observations of the 1984 Lazio-Abruzzo earthquakes: implications for the active tectonics of Italy. Geophysical Journal of the Royal Astronomical Society 98, 489-514.

Willemse, E.J.M., 1997. Segmented normal faults: correspondence between three-dimensional mechanical models and field data. Journal of Geophysical Research 102, 675-692.

Working Group on California Earthquake Probabilities (WG99), 1999. Earthquake Probabilities in the San Francisco Bay Region: 2000 to 2030 - a summary of findings. U.S. Department of the Interior, U.S. Geological Survey, Open File Report 99-517. 